UNIVERSIDADE DE SÃO PAULO

FACULDADE DE ECONOMIA, ADMINISTRAÇÃO E CONTABILIDADE

DEPARTAMENTO DE CONTABILIDADE E ATUÁRIA

PROGRAMA DE PÓS-GRADUAÇÃO EM CONTROLADORIA E CONTABILIDADE

O PROCESSO DE GESTÃO E CONTROLE DOS FLUXOS DE CAIXA EM UM BANCO BRASILEIRO: UMA ANÁLISE À LUZ DA ABORDAGEM DO CICLO DE VIDA ORGANIZACIONAL

Cristiano Prudencio

Orientador: Prof. Dr. Carlos Alberto Pereira

SÃo PAULO

2012 
Prof. Dr. João Grandino Rodas

Reitor da Universidade de São Paulo

Prof. Dr. Reinaldo Guerreiro

Diretor da Faculdade de Economia, Administração e Contabilidade

Prof. Dr. Edgard Bruno Cornacchione Júnior Chefe do Departamento de Contabilidade e Atuária

Prof. Dra. Silvia Pereira de Castro Casa Nova

Coordenadora do Programa de Pós-Graduação em Controladoria e Contabilidade 


\section{CRISTIANO PRUDENCIO}

O PROCESSO DE GESTÃO E CONTROLE DOS FLUXOS DE CAIXA EM UM BANCO BRASILEIRO: UMA ANÁLISE À LUZ DA ABORDAGEM DO CICLO DE VIDA ORGANIZACIONAL

Dissertação apresentada ao Departamento de Contabilidade e Atuária da Faculdade de Economia, Administração e Contabilidade da Universidade de São Paulo, para obtenção do título de Mestre em Ciências.

Orientador: Prof. Dr. Carlos Alberto Pereira

\section{Versão Corrigida}

(versão original disponível na Unidade que aloja o programa)

\section{SÃO PAULO}




\section{FICHA CATALOGRÁFICA}

Elaborada pela Seção de Processamento Técnico do SBD/FEA/USP

\section{Prudencio, Cristiano}

O processo de gestão e controle dos fluxos de caixa em um banco brasileiro: uma análise à luz da abordagem do ciclo de vida organizacional / Cristiano Prudencio. -- São Paulo, 2012.

$177 \mathrm{p}$.

Dissertação (Mestrado) - Universidade de São Paulo, 2012.

Orientador: Carlos Alberto Pereira.

1. Controladoria 2. Fluxo de caixa 3. Instituições financeiras - Brasil I. Universidade de São Paulo. Faculdade de Economia, Administração e Contabilidade II. Título.

CDD - 658.151 
À minha amada esposa Juliana por todo amor e carinho.

A toda minha família e amigos. 



\section{AGRADECIMENTOS}

Agradeço primeiramente a Deus que me deu luz, força, saúde e criou as condições necessárias para cumprir o desejo do meu coração. Agradeço a todo amor, carinho e dedicação de minha esposa Juliana, que foi minha auxiliadora durante todos os momentos de dificuldade e demonstrou paciência e compreensão enquanto dedicava as minhas horas livres ao meu curso, me incentivando e compartilhando esta conquista comigo.

Também sou grato a todas as pessoas que de alguma forma fizeram parte desta jornada em minha vida.

Ao meu orientador, Professor Carlos Alberto Pereira, pelas discussões, ensinamentos, conselhos, apoio e estímulo. Aos Professores Iran Lima e Francisco Fernandes pelas valiosas contribuições ao trabalho.

Aos Professores Ariovaldo dos Santos, Bruno Salotti, Fábio Frezatti, Gerlando Lima, Luis Eduardo Afonso, Marcio Borinelli, Nelson Carvalho, Reinaldo Guerreiro e Wellington Rocha, pelo aprendizado nas disciplinas que tive a oportunidade de cursar.

A todos meus colegas da Pós-Graduação, em especial ao Adriano Bertoldo e ao Marcelo Barroso pela amizade, contribuições nos estudos e discussões em relação a este trabalho. A FEA-USP e a todos os seus funcionários, e à administração da instituição estudada que me abriu as portas para a realização da pesquisa, e a todos os colaboradores da instituição que participaram da pesquisa, pela sua solicitude, colaboração e valiosa contribuição, tanto na participação como nas discussões sobre o trabalho.

Aos meus superiores na instituição na qual sou colaborador, que permitiram que integrasse o PPGCC, e aos meus colegas de trabalho que suportaram minhas ausências em função dos estudos e me auxiliaram em discussões e reflexões.

Agradeço também aos meus pais Célia e Luiz, à minha avó Francisca e ao meu avô José (in memoriam), pela educação, conselhos, exemplos e apoio ao meu crescimento que, de algum modo, me propiciaram chegar a esta etapa.

Aos meus sogros, João e Onísia que me receberam de braços abertos, com grande carinho, como integrante de sua família, aos meus cunhados Eliane, Alexandre, Junior e Raquel com quem tive a rica oportunidade de compartilhar muitos bons momentos de minha vida, e a toda a minha família, a advinda do berço, e a que me recebeu com muita alegria desde a época do meu namoro. 

"Deus não é homem, para que minta; nem filho do homem, para que se arrependa; porventura diria ele, e não o faria? Ou falaria, e não o confirmaria?" Bíblia, Números Cap.23 Verso 19 



\section{RESUMO}

Este trabalho tem por objetivo ampliar o conhecimento sobre a atividade de gestão e controle dos fluxos de caixa no setor bancário, sendo esta não muito explorada em pesquisas e literatura, contribuindo, deste modo, para um melhor entendimento da atividade, uma vez que a gestão ótima dos fluxos de caixa é muito importante para qualquer empresa, sendo esta tarefa ainda mais crítica para um banco, pois a correta alocação dos recursos financeiros contribui para a otimização dos seus resultados. Para tanto, foi realizado um estudo de caso em um banco brasileiro no qual foram coletadas as percepções de diversos colaboradores e gestores de áreas distintas, finanças, risco e tesouraria, acerca das características do processo de gestão e controle dos fluxos de caixa e da instituição como um todo, verificando a existência de relacionamento dessas com o estágio no ciclo de vida organizacional no qual a instituição está inserida. Numa primeira etapa, pretendeu-se analisar as percepções advindas da aplicação do questionário, sendo, estas, representações da visão das equipes diretamente relacionadas com o processo de gestão e controle dos fluxos de caixa. Essa etapa buscou o entendimento das relações entre as variáveis corporativas e as variáveis contextuais no que tange ao processo de gestão e controle dos fluxos de caixa, por meio da abordagem do ciclo de vida organizacional, captando aspectos relevantes, bem como a convergência ou divergência de percepções entre as equipes. Esses achados foram contrastados com a coleta das percepções materializadas por meio das entrevistas realizadas com os gestores gerais de cada área, de modo a triangular as percepções e construir as características predominantes do processo de gestão e controle dos fluxos de caixa e do ciclo de vida organizacional da instituição, bem como dos relacionamentos identificados, sejam eles convergentes ou divergentes. Adicionalmente buscou-se entender também a existência ou inexistência de relação entre o orçamento e esse processo. Sendo assim o trabalho contribuiu com o desenvolvimento de um construto teórico para análise do problema, embasado em diversos excertos de estudos esparsos; para a validação da possibilidade de utilização em uma instituição financeira do modelo de enquadramento de empresas nos estágios do ciclo de vida organizacional; e principalmente para demonstrar a existência de relação entre o processo de gestão e controle dos fluxos de caixa e o seu estágio no ciclo de vida organizacional, suscitando diversas proposições, servindo como ponto de partida para pesquisas futuras. 



\begin{abstract}
This work aims to expand the knowledge about the activity of cash flow management and control in the banking sector, which is not much explored in research and literature, thus contributing to a better understanding of this activity, since for any company to optimize cash flows management is important, and this task is even more critical to a bank, because the right resource allocation may contribute to optimize their results. For this purpose, a case study in a Brazilian bank was conducted in which was collected the perceptions of many employees and managers from different areas, finance, risk management and treasury, about the characteristics of cash flows management and control process and about the institution as a whole, by checking the relationship of these to the stage in the organizational life cycle in which institution is located. In a first step, sought to analyze the perceptions arising from the application of the questionnaire, these being the representations of the vision of the teams directly related to the process control and management of cash flow. This step aims to understand the relationship between the corporate variables and contextual variables, in relation to cash flow management and control process, by addressing organizational life cycle, capturing relevant aspects, and the convergence or divergence of perceptions between the teams. These findings were contrasted with collection of perceptions materialized through interviews with general managers in order to triangulate the perceptions and build the predominant features of cash flow management and control process and organizational life cycle of this institution, furthermore to identify if the relationship between it were convergent or divergent. Additionally were sought to understand either the existence or lack of relationship between budgeting and this process. This way, the work contributed to the development of a theoretical framework for analyzing the problem, based on several passages of sparse studies; to validate the possibility of use in a financial institution's business model framework stages of the organizational life cycle; and mainly to demonstrate the existence of a relationship between cash flow management and control process and its stage in the organizational life cycle, raising several propositions, serving as a starting point for future research.
\end{abstract}





\section{SUMÁRIO}

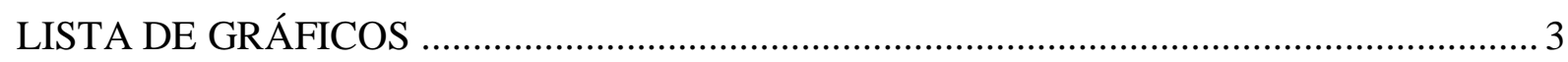

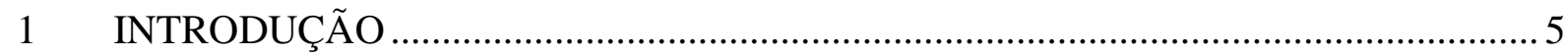

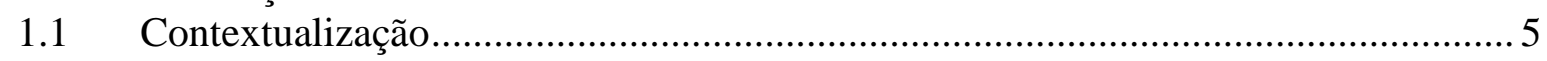

1.2 Questão de pesquisa......................................................................................... 10

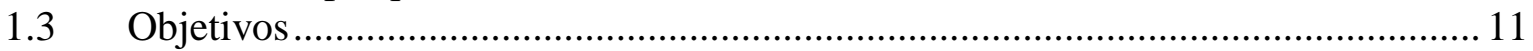

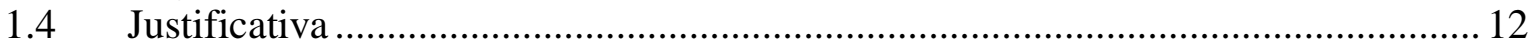

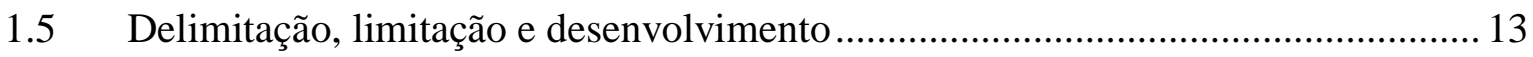

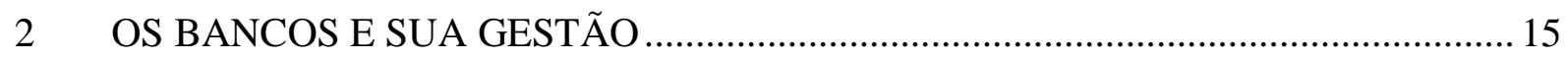

$2.1 \quad$ Contexto geral acerca dos bancos...................................................................... 15

2.2 O ambiente regulatório e sua influência na gestão do caixa....................................... 16

2.2.1 Os Acordos de Basileia e sua interferência na gestão dos fluxos de caixa .... 16

2.2.2 FGC como agente do processo de gestão dos fluxos de caixa ......................... 19

2.2.3 Os depósitos compulsórios e gestão e controle dos fluxos de caixa ................21

2.3 Histórico dos bancos brasileiros: relatos e estatísticas ...............................................2 23

2.3.1 Um breve relato histórico acerca do mercado bancário brasileiro ................... 23

2.3.2 O mercado bancário em números: estatísticas do BACEN - dos primórdios ao

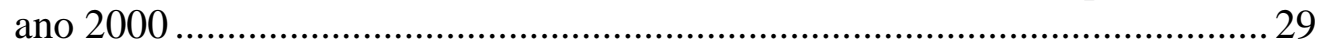

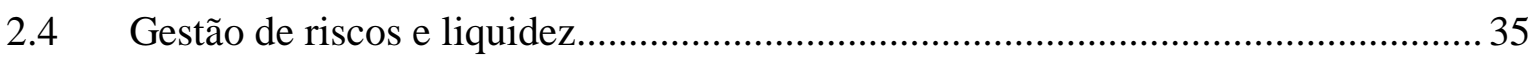

2.4.1 Riscos e liquidez: conceitos e características gerais ....................................... 35

2.4.2 O Exemplo FED: aspectos da política norte-americana de controle e gestão da liquidez, do seu risco e os estudos empíricos relacionados............................. 39

2.5 Gestão tradicional: gestão do caixa …………………………………………….... 41

3 ESTUDOS ACERCA DA GESTÃO DO CAIXA: AS ABORDAGENS E OS ACHADOS EMPÍRICOS ..................................................................................... 47

4 A PARTICIPAÇÃO DA CONTABILIDADE NA GESTÃO DOS BANCOS E DOS

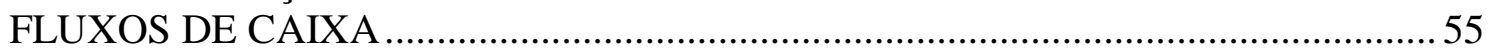

4.1 Contabilidade: sua essência gerencial e sua contribuição à gestão bancária .............55

4.2 Artefatos, técnicas e modelos contábeis: seu auxílio e participação na gestão e

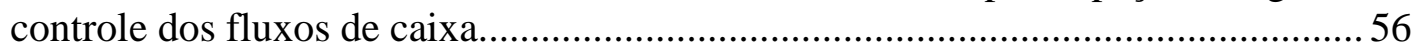

5 A ABORDAGEM DO CICLO DE VIDA ORGANIZACIONAL.................................... 63

6 O INTER-RELACIONAMENTO DAS TEMÁTICAS TEÓRICAS E A FORMAÇÃO

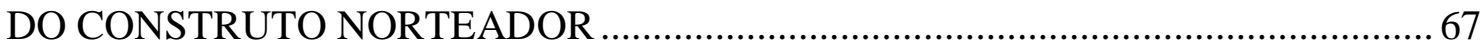

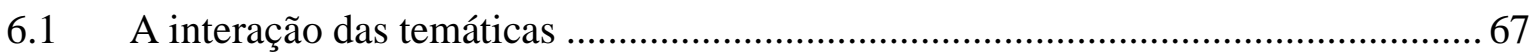

6.2 Modelo de gestão: envolvidos, perfil e enfoque ........................................................... 67

6.3 Elementos da gestão e controle dos fluxos de caixa ................................................... 70

6.4 Proposta da constituição do processo de gestão e controle dos fluxos de caixa.......73

6.5 Interação entre o contexto e o processo de gestão e controle dos fluxos de caixa .. 74

6.6 Delineamento do construto norteador........................................................................ 76

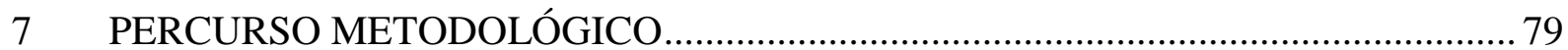

7.1 Considerações metodológicas introdutórias: aspectos gerais e escolhas realizadas 79

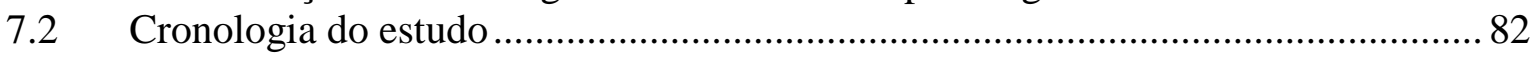

7.3 Protocolo do estudo de caso................................................................................ 83

7.4 Questionário: referencial e delineamento ………………………………………..... 84 
7.4.1 Dimensões características do processo de gestão e controle dos fluxos de caixa, de sua utilização e do estágio no ciclo de vida organizacional ............ 86

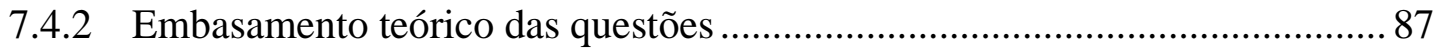

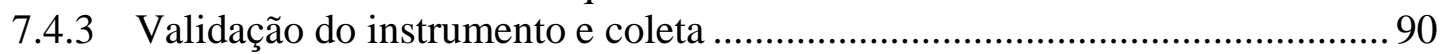

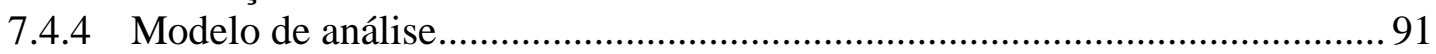

7.5 Entrevista: delineamento e embasamento do roteiro ............................................ 93

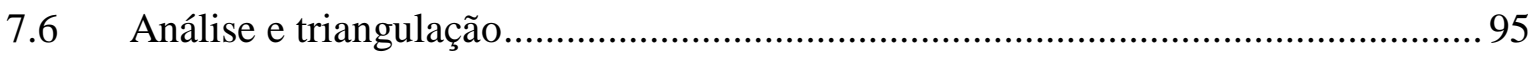

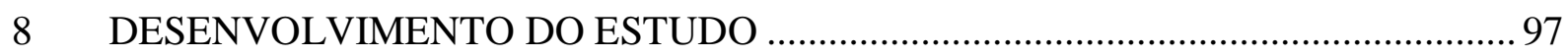

8.1 Participação do orçamento na gestão e controle dos fluxos de caixa ....................... 97

8.2 Convergência e ou Divergência de percepções acerca do processo de gestão e controle dos fluxos de caixa........................................................................... 100

8.3 Relacionamento entre o estágio no ciclo de vida organizacional e o processo de gestão e controle dos fluxos de caixa................................................................ 110

8.3.1 Formatação e direcionamento da análise................................................ 110

8.3.2 Análise do estágio no ciclo de vida organizacional .................................... 113

8.3.3 Análise da relação entre o estágio no ciclo de vida organizacional e o processo de gestão e controle dos fluxos de caixa ....................................... 117

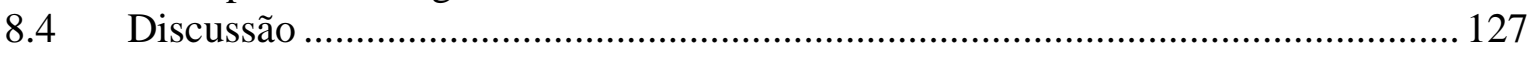

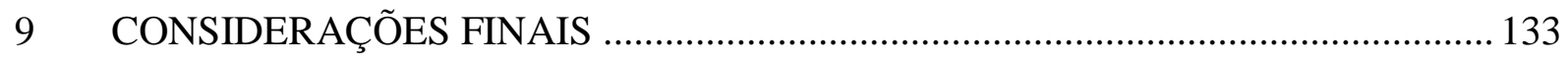

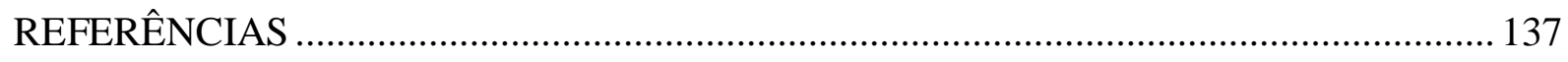

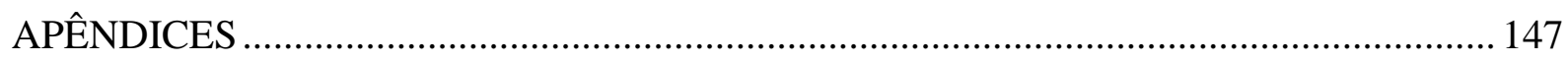




\section{LISTA DE GRÁFICOS}

Gráfico 1 - Banco por origem do controle e por ano de início de funcionamento................30

Gráfico 2 - Bancos por tipo em funcionamento .................................................. 30

Gráfico 3 - Bancos em funcionamento em 1988 encerrados nos anos seguintes ...................31

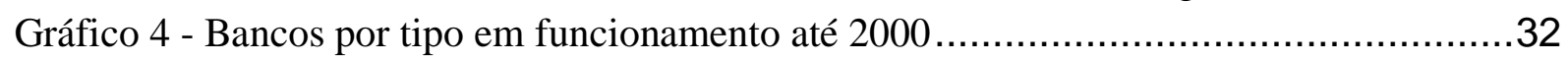

Gráfico 5 - Participação e concentração bancária .................................................33

Gráfico 6 - Participação dos top cinco, dez e vinte ................................................34

Gráfico 7 - Participação por Origem de Controle ............................................... 34

Gráfico 8 - Participação do orçamento..................................................................

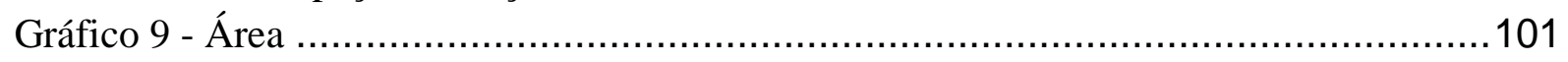

Gráfico 10 - Perfil....................................................................................... 101

Gráfico 11 - Perfil de Finanças ..................................................................... 104

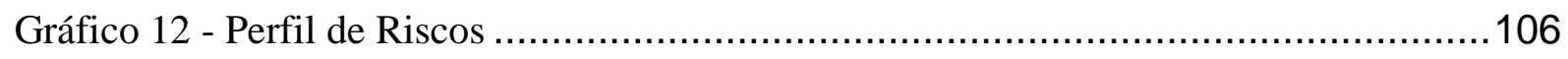

Gráfico 13 - Perfil Tesouraria................................................................. 108

Gráfico 14 - Ciclo de vida organizacional ...................................................... 114

Gráfico 15 - ANACOR Fluxo de caixa ................................................................ 119

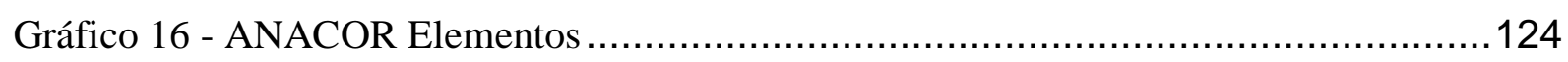

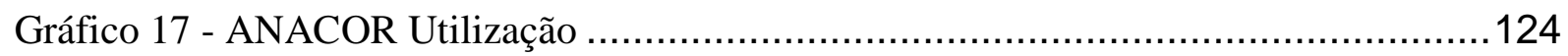

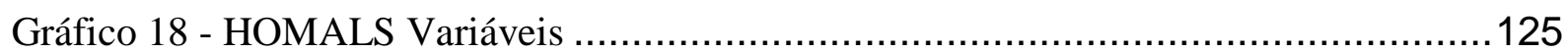




\section{INTRODUÇÃO}

\subsection{Contextualização}

Instituições financeiras têm entre suas principais finalidades a intermediação de recursos entre agentes deficitários e superavitários de liquidez (ASSAF NETO, 2006b). Normalmente, atuam em sistemas com forte regulação governamental e possuem ampla divulgação quanto às informações contábeis. Suas operações são bastante dinâmicas, haja vista a principal matéria-prima ser moeda corrente, seja ela representada em papel moeda de fato ou convertida em um instrumento financeiro. Diversos entes se enquadram na classificação de instituição financeira, porém os bancos são os que mais se enquadram na estrutura de análise desenvolvida para este estudo, sendo, portanto, o foco deste estudo de caso.

No que tange à gestão, na qual participam, por exemplo, a controladoria, a área responsável pelo gerenciamento de riscos, entre outras áreas, os bancos controlam desde indicadores tidos como clássicos, como o retorno sobre o investimento, que alia lucro e patrimônio, passando por extensões mais sofisticadas, como o retorno em condições de risco e alocação de capital (BRITO, 2000), assim como o controle de seus fluxos financeiros, comumente denominado de fluxos de caixa (SANTOS, 2005).

Em especial, com relação às práticas de gestão em instituições bancárias, pode-se afirmar que a gestão e controle do caixa e dos seus fluxos merecem especial atenção (BESSIS, 1998; HEMPEL; SIMONSON, 1998; ALCÂNTARA, 2007; PRADO; MARTINS, 2009; PEROBELLI et al., 2007; BRITO, 2000), pois a maior parte dos ativos e passivos é de natureza financeira, muitas vezes com expectativa de realização em curto horizonte de tempo, como também para que oportunidades lucrativas de intermediação financeira possam ser aproveitadas.

Estas oportunidades lucrativas são representadas por aplicações e ou captações tempestivas de recursos, em boas condições de taxas de juros, prazo e risco, bem como por demandas emergenciais de recursos, permitindo, deste modo, que a gestão e controle dos fluxos de caixa sejam feitos de forma ótima, resultando de forma sistêmica em indicadores de retorno 
positivamente afetados por este processo. Esta afirmação é corroborada pelo trabalho de Rogers, Rogers e Ribeiro (2005), no qual os autores afirmam que o caixa é fruto de várias ações como políticas de investimentos e financiamentos, vendas e compras; ações estas que envolvem diversas áreas, sendo necessária, para o processo decisório, a sincronização das entradas e saídas de modo que a instituição não se torne ilíquida ou mantenha excesso de liquidez, incorrendo em altos custos de oportunidade. Não obstante, a gestão dos fluxos de caixa é tida como importante por diversos estudiosos cujos segmentos econômicos analisados não foram especificamente o das instituições financeiras, a exemplo de Zdanowicz (1995), Rogers, Rogers e Ribeiro (2005), Alves e Marques (2007), Frezatti (1997), Silva e Neiva (2010), e Cheng, Tsai e Sudjono (2010).

Segundo Frezatti (1997), é importante que os gestores compreendam que o lucro nem sempre se transformará em caixa no longo prazo em função de vários elementos como inadimplência, não pontualidade, provisões e depreciação, entre outros itens, tornando, deste modo, o acompanhamento do caixa essencial. De acordo com Zdanowicz (1995), o fluxo de caixa é o instrumento que permite ao administrador financeiro: planejar, organizar, coordenar, dirigir e controlar os recursos financeiros de sua instituição num determinado período. Para Silva e Neiva (2010), dentre os artefatos gerenciais dinâmicos, o fluxo de caixa merece destaque por sua estreita relação com a situação de liquidez da instituição, sendo a liquidez relacionada com a capacidade de obtenção de fundos a um custo razoável (BESSIS, 1998) e, pela potencialidade de projetar situações futuras, deste modo o desenvolvimento de ferramentas que auxiliem a decisão baseada em caixa deve ser incentivado.

Outra importante contribuição para a discussão dessa temática, dada por Carvalho (1993), aponta que o avanço da tecnologia propiciou maior facilidade na elaboração de modelos de administração de liquidez, incluindo modelos de simulação com múltiplos cenários e produtos, com característica dinâmica e com alto poder informativo. Para tanto, Carvalho (1993) afirma que quatro itens fundamentais devem ser observados na ocasião da construção desses modelos: a qualidade dos dados, a precisão das premissas, a precisão da construção do modelo e a exposição ao risco gerado pelo modelo, itens que irão requerer bastante esforço, atenção e gestão efetiva para que os processos possam ser desenvolvidos adequadamente.

Adicionalmente, segundo Carvalho (1993), um dos tipos de simulação, aquela dinâmica, que representa o efeito dos juros nos ativos e passivos e consecutivamente do próprio mix pode 
auxiliar no dimensionamento dos impactos, considerando uma situação de inércia da gestão, constituindo, portanto, um modelo de análise do gap dinâmico que, por sua vez, é um modelo que representa a diferença entre ativos e passivos, tanto remanescentes como projetados, com o intuito de prover a adequada situação de liquidez, tanto em natureza dos instrumentos como dos seus prazos. No entanto, Carvalho (1993) afirma que esses modelos estarão sujeitos a expertise do seu criador e dos seus operadores, podendo esta ser frutífera ou danosa; sujeitos também à disponibilidade e qualidade dos dados; e, na ausência destes, também dependente da qualidade das premissas adotadas para suprimento das lacunas informacionais.

Baseando-se na importância teórica, nos apontamentos e na atenção dada pelos estudos supracitados evidencia-se a necessidade de eficientes e eficazes gestão e controle dos fluxos de caixa em instituições financeiras. Esta gestão e controle devem ser efetuados tanto na forma de acompanhamento do saldo de caixa, quanto da previsão e controle dos fluxos no curtíssimo prazo, como também de uma boa projeção de curto e de longo prazo. Desta forma, estas atividades demandam de seus gestores atenção contínua à destinação adequada para novos recursos disponíveis e ou decisão tempestiva quanto ao ativo que será sacrificado para arcar com determinado passivo.

Para tanto, a realização da gestão e controle dos fluxos de caixa demanda a compreensão de sua função, da forma como é realizada, de quem são os agentes envolvidos e de quais os elementos e variáveis essenciais para esse processo dentro de um banco e principalmente de como o ambiente interage com esse processo. Nesta seara de desvendar o processo de gestão e controle dos fluxos de caixa, diversos autores buscaram características que pudessem diferenciar o processo desenvolvido nas organizações.

Como exemplo destas características, Kytönen (2004) divide a gestão do caixa em tática e estratégica, contribuindo para a assunção da existência de diferentes abordagens de utilizações do fluxo de caixa, partindo de uma visão fortemente estratégica, possivelmente passando por estágios intermediários, até uma visão extremamente tática, podendo esta utilização estar ligada de alguma forma ao contexto no qual a instituição está inserida. Phillips (1997) e Frezatti (1997) também confirmam a existência desta característica. 
Em se tratando da pesquisa relacionada à gestão de caixa nas organizações, essa temática está distribuída em diversos ramos do conhecimento. No contexto da gestão dos fluxos de caixa, tanto a administração, focada ou não focada em riscos, como a contabilidade, têm de algum modo estudado a temática, sendo a administração com foco em riscos, como também a com foco em finanças, as áreas que mais produzem conhecimentos específicos relacionando caixa e instituições financeiras, seguidas da economia e, por fim, da contabilidade. A nomenclatura da temática dos trabalhos relacionados varia, sendo eles profissionais e ou científicos, encontrando-se, desta forma, as nomenclaturas de gestão de caixa, gestão de tesouraria, gestão dos riscos de liquidez, entre outras.

Trabalhos referenciais como o de Bessis (1998), que trata da liquidez pela ótica do risco, e de Hempel e Simonson (1998), que destacam a gestão do caixa em bancos, são pontos de partida para discussão do assunto. Diversos outros trabalhos científicos, como os de Iturralde, Maseda e San-Jose (2008; 2009), Phillips (1997), Ozkan e Ozkan (2004), Soenen (1986), Opler et al. (1999), Kim, Mauer e Sherman (1998) e Frezatti (1997), tratam da temática pela ótica da gestão de caixa e de tesouraria seguindo uma ótica generalista no que tange ao segmento empresarial, e contribuem para trazer à tona aspectos interessantes para a temática.

Muitas outras características e ou variáveis são abordadas por diversos outros estudos, entre elas o perfil de gestores (FREZATTI, 1997), sendo ativamente participante ou passivo na gestão; a centralização ou descentralização do processo de gestão (SOENEN, 1986; ITURRALDE; MASEDA; SAN-JOSE, 2009), a escolaridade dos gestores (ITURRALDE; MASEDA; SAN-JOSE, 2009), técnicas de projeção, incluindo orçamento de caixa, e sua periodicidade (SOENEN, 1986; KYTÖNEN, 2004; ITURRALDE; MASEDA; SAN-JOSE, 2009; FREZATTI, 1997), relacionamento com fornecedores e clientes de recursos (ITURRALDE; MASEDA; SAN-JOSE, 2009; PHILLIPS, 1997; SOENEN, 1986), tecnologia utilizada (PHILLIPS, 1997; SOENEN, 1986; FREZATTI, 1997), controle acionário (OZKAN; OZKAN, 2004); conflitos interdepartamentais (SOENEN, 1986); fontes de informação que fornecerão os dados necessários para a tarefa (FREZATTI, 1997); granularidade das informações representada pelos direcionadores escolhidos quer sejam eles contas quer sejam produtos (FREZATTI, 1997); a formatação dos relatórios de controle e análise dos fluxos de caixa (FREZATTI, 1997); a área e ou setor de atuação (ITURRALDE; MASEDA; SAN-JOSE, 2009); filosofia e cultura de gestão (ITURRALDE; MASEDA; SANJOSE, 2008, 2009). 
Frente aos elementos supracitados nos estudos que permeiam e condicionam o processo de gestão e controle dos fluxos de caixa, e diante da importância deste processo para as instituições financeiras, evidencia-se uma necessidade de análise e investigação para compreender como estes elementos estão dispostos e como eles contribuem para uma adequada utilização do processo pelos bancos de forma que possam atingir um controle ótimo e adequado ao seu contexto. Sendo assim, esta temática, alvo da pesquisa em risco, finanças e economia, pode também ser alvo, de forma mais aprofundada, da pesquisa em contabilidade, de modo que as abordagens e conhecimentos existentes nas Ciências Contábeis possam auxiliar o processo de gestão e controle dos fluxos de caixa.

Indo além, com relação ao processo decisório, não menos importante é o ponto ressaltado por Silva e Neiva (2010), quanto à capacidade preditiva dos fluxos de caixa. Esta capacidade pode ser muito útil para o processo decisório, principalmente se aliada à outra ferramenta consolidada no âmbito empresarial, denominada orçamento, que se dispõe a projetar e estimar saldos e resultados futuros e quiçá até mesmo o caixa. Deste modo, outro intrigante ponto é o relacionamento do controle dos fluxos de caixa com o processo orçamentário, sendo o controle dos fluxos de caixa inserido no processo orçamentário e ou processos relacionados, conforme os estudos de Soenen (1986), Kytönen (2004), Iturralde, Maseda e San-Jose (2009), ou sendo eles completamente apartados.

A depender da miríade de fatores sobre a qual determinados sistemas de controle gerencial serão encontrados e eventualmente associados com melhor desempenho da organização (CHENHALL, 2006), como nicho de atuação, tempo de vida, tamanho, estrutura organizacional, mecanismos de controle, modelo de gestão, entre outros, a forma e o conteúdo dos processos de gestão e controle dos fluxos de caixa, assim como da sua intersecção com o processo orçamentário para controle e gestão do caixa, podem variar.

Seguindo esta linha de raciocínio, além dos elementos e variáveis inerentes ao processo de gestão e controle dos fluxos de caixa, e do seu suposto relacionamento com o processo orçamentário, fatores contextuais, como os supracitados, poderão ter influência na determinação e explicação da adoção de determinados elementos do processo de controle e do relacionamento com o orçamento. Deste modo, pacotes de fatores contextuais influenciariam 
pacotes de fatores processuais, sendo que cada grupo de instituições procuraria adequar seus controles ao seu pacote de fatores contextuais dentre eles tamanho, tempo de vida, estratégia, estrutura organizacional, modelo de gestão, entre outros. Sob esta égide, a abordagem do ciclo de vida organizacional, abordagem esta presente em diversos estudos desenvolvidos em contabilidade, poderia ser útil na tentativa de relacionar as escolhas e características do controle dos fluxos de caixa aos fatores contextuais existentes na instituição em análise.

Esta abordagem, nascida de uma analogia ao ciclo de vida biológico, tenta relacionar as práticas e utilização de um determinado processo e ou ferramenta com os fatores contextuais presentes em cada um dos ciclos da vida organizacional. A abordagem do ciclo de vida (LESTER; PARNELL; CARRAHER, 1993; MILLER; FRIESEN, 1983, 1984; MOORES; YUEN, 2001) representa uma forma de lidar com tais fatores, pois analisa características dos arquétipos organizacionais à medida que as organizações evoluem e se transformam como forma de adaptação a diversos fatores externos e internos. Espera-se que essa abordagem auxilie na compreensão da metodologia de gestão e controle dos fluxos de caixa utilizada pelo banco em análise, bem como da sua possível interação com o processo orçamentário.

Muitos estudos já foram realizados relacionando os processos e ferramentas gerenciais com a abordagem do ciclo de vida organizacional, cada qual com suas peculiaridades. Para embasar a presente pesquisa foi selecionado o estudo de Lester, Parnell e Carraher (1993), devido à sua transparência metodológica que permite a reprodução em outros estudos. $\mathrm{O}$ trabalho de Lester, Parnell e Carraher (1993), por sua vez, se baseia nos estudos de Miller e Friesen $(1983,1984)$.

\subsection{Questão de pesquisa}

Sobre essas inquietações relacionadas à gestão e controle dos fluxos de caixa em bancos, assentadas sobre a possível influência dos fatores contextuais, característicos dos estágios do ciclo de vida organizacional, está calcada a questão de pesquisa deste estudo: Qual a aderência do processo gestão e controle dos fluxos de caixa ao estágio da instituição no ciclo de vida organizacional? 


\section{$1.3 \quad$ Objetivos}

Em relação à questão de pesquisa, este trabalho tem os seguintes objetivos:

\section{Objetivo geral:}

Analisar a aderência do processo de gestão e controle de fluxos de caixa de uma instituição bancária ao seu estágio de desenvolvimento, conforme proposições da abordagem do ciclo de vida organizacional.

\section{Objetivos específicos:}

I. Identificar o estágio de desenvolvimento da instituição com base na abordagem do ciclo de vida organizacional,

II. Caracterizar o processo de gestão e controle dos fluxos de caixa em uma instituição bancária com base no construto teórico delineado;

III. Verificar a existência de correspondência entre as características do processo de gestão e controle dos fluxos de caixa e o estágio da instituição no ciclo de vida organizacional;

IV. Relatar a possível participação do orçamento no controle dos fluxos de caixa, demonstrando a interação e ou independência entre o controle orçamentário e o controle do caixa.

Como esclarecimento, é importante ressaltar que as características do processo de gestão e controle presentes no objetivo específico e no decorrer do trabalho, conforme enunciados anteriormente, representam os elementos fundamentais e variáveis que delimitam como este processo se desenvolve nos bancos brasileiros. O contexto representa as variáveis que determinam em qual estágio do ciclo de vida o banco em estudo se enquadra, seguindo para isto a metodologia proposta por Lester, Parnell e Carraher (1993). Todos estes aspectos serão explorados com maior profundidade nas próximas seções. 


\section{$1.4 \quad$ Justificativa}

Conforme citado anteriormente, a gestão do caixa é um processo de suma importância para todas as instituições e em especial para as instituições financeiras, cujo foco é a intermediação financeira entre agentes superavitários e deficitários, sendo que a maioria de seus ativos e passivos é de natureza financeira, e que a ausência ou o excesso de caixa propicia no mínimo uma ineficiência de resultados, quer seja por manter o caixa excedente aplicado em ativos de baixo rendimento, quer seja por necessitar de captações emergenciais a um custo elevado para cobrir eventuais obrigações, e que, no limite, pode causar a quebra da instituição.

Outro importante fato a destacar é que a contabilidade que, em linhas gerais, pretende fornecer informações de qualidade e tempestivas para subsidiar a tomada de decisão, e que no seu veio gerencial se dispõe a induzir e guiar os gestores à tomada de decisão ótima, pouco tem se debruçado na pesquisa acerca da gestão e controle dos fluxos de caixa, ou mesmo de temas mais limitados, porém relacionados, como o orçamento de caixa (LEITE et al., 2008), principalmente no que tange às instituições financeiras, havendo, portanto, espaço para que haja contribuições quanto a esta temática.

Mesmo em outras áreas do conhecimento como a gestão financeira, a gestão de riscos e a economia nas quais são encontrados mais estudos acerca do tema (SOENEN; 1986; OZKAN; OZKAN, 2004; KYTÖNEN, 2004; ITURRALDE; MASEDA; SAN-JOSE, 2009), ainda assim são escassos os estudos que se aventuram a investigar as práticas de controle e gestão de fluxos de caixa nas instituições (KYTÖNEN, 2004).

Portanto, pautado na pouca publicação científica contábil abordando a temática de gestão e controle dos fluxos de caixa, dada a importância do entendimento e da adequada gestão deste processo para a otimização do resultado global e boa saúde financeira dos bancos, como também da lacuna de pesquisas acerca do assunto mesmo em outras áreas do conhecimento, justifica-se este estudo que se propõe a clarificar as práticas de controle e gestão dos fluxos de caixa em uma instituição financeira e relacioná-las com as variáveis contextuais por meio de uma abordagem existente nos estudos de controle gerencial, propiciando uma contribuição para preencher a lacuna científica existente, e ainda que de forma limitada, para o entendimento da prática da gestão e controle dos fluxos de caixa. 


\subsection{Delimitação, limitação e desenvolvimento}

Em função da característica da estratégia de pesquisa utilizada, este estudo não possibilita a generalização dos seus resultados, sendo esta uma delimitação natural e esperada quando se trata de um estudo de caso. Outra delimitação refere-se à não divulgação do nome e de qualquer dado que venha possibilitar a identificação da instituição em que foi realizado o estudo, bem como dos profissionais que participaram do estudo. Esta condição foi determinante para viabilizar a pesquisa, porém não interferiu nos seus resultados, sendo esta também uma prática comum em estudos de caso.

Do mesmo modo, é importante ressaltar que os achados e suas conclusões serão pautados nas percepções dos colaboradores questionados e entrevistados, sendo estas sujeitas às suas crenças, valores, postura crítica, vivência, entre outros aspectos pessoais importantes que podem exercer algum tipo de influência, configurando-se como uma limitação deste estudo. Outra limitação que merece destaque refere-se à construção do modelo teórico que relaciona ciclo de vida e fluxo de caixa e que embasa todas as análises, sendo este um construto depreendido pelo autor deste estudo, com base em diversos excertos teóricos concatenados, proposições e premissas. A inexistência de um modelo teórico existente para analisar o problema descrito neste estudo resultou na necessidade da criação de um modelo inédito de análise. Entretanto, caso esta nova construção teórica não esteja adequada ao problema, poderá gerar conclusões inadequadas.

O estudo se desenvolverá da seguinte forma: a seguir serão apresentados aprofundamentos às temáticas acima abordadas, delineando conceitos acerca da natureza da operação dos bancos e do seu processo de gestão, aprofundamentos acerca da prática da gestão e controle dos fluxos de caixa, do possível papel do orçamento neste contexto, do histórico da abordagem do ciclo de vida, e do inter-relacionamento destas temáticas. Estas seções têm, portanto, o objetivo de trazer informações relevantes e reforçar a questão de pesquisa e sua justificativa.

Em seguida, estarão descritos os construtos teóricos que permeiam a pesquisa, com suas premissas e considerações, bem como o detalhamento metodológico, tendo este suma importância para o entendimento das etapas utilizadas para análise, entre elas a aplicação de questionário e realização das entrevistas. Por fim, estes dados foram submetidos a análises e 
triangulações de modo a fundamentar as conclusões e considerações apresentadas ao final. Como apêndices são apresentados os instrumentos de coleta e quadros de apoio. 


\section{OS BANCOS E SUA GESTÃO}

\subsection{Contexto geral acerca dos bancos}

O mercado financeiro consiste em um conjunto de agentes e instrumentos destinados a oferecer alternativas de aplicação e captação de recursos financeiros (LIMA; LIMA; PIMENTEL, 2006, p. 2). Entre as suas diversas funções, o mercado financeiro permite uma melhor alocação de recursos na economia e a pulverização de risco. A composição do mercado financeiro compreende todos os agentes possuidores e ou que necessitem de recursos, os órgãos que regulam as atividades de intermediação financeira, bem como as instituições financeiras que realizam a intermediação entre os agentes. Estas instituições estão dispostas na forma de seguradoras, corretoras, distribuidoras de títulos, cooperativas de crédito e de bancos, sendo, a última forma societária, o foco deste estudo.

Bancos realizam um negócio muito dinâmico e peculiar. A principal atividade consiste na intermediação de recursos financeiros entre agentes superavitários e deficitários interessados, respectivamente, na aplicação desse superávit ou no empréstimo de recursos para cobertura desse déficit. De um lado, têm-se poupadores, agentes visando manter a essência do patrimônio por meio de ativos de valorização estável e mínimo nível de risco. De outro, têmse tomadores de recursos, agentes visando incrementar a própria riqueza de ativos reais por meio da aplicação dos recursos tomados em investimentos rentáveis (ASSAF NETO, 2006a).

Como intermediadores financeiros, os bancos procuram satisfazer, simultaneamente, o portfólio de preferências destes dois grupos distintos de agentes econômicos que com eles se relacionam, visando assim à maximização do próprio lucro. A dinâmica dessa atividade advém da variedade de situações de oferta e de demanda de recursos pelas pessoas físicas e jurídicas e outras instituições financeiras com quem eles se relacionam no âmbito dessa atividade de intermediação financeira.

Nesse contexto, essas instituições operam diversos produtos financeiros, visando a atender os mais diversos clientes e suas demandas específicas. Em cada situação, procuram identificar oportunidades de captação e de empréstimo de recursos que lhes possibilitem maximizar o 
spread bruto, a diferença entre a taxa de juros cobrada do tomador de recursos e a paga ao aplicador.

Como a principal matéria-prima das instituições financeiras é a moeda, no sentido mais amplo da palavra, sendo esta convertida em título, recebível, derivativo, ou mesmo em espécie, considerando também a suscetibilidade de ativos e passivos financeiros a fatores macroeconômicos diversos, essas instituições devem criar controles adequados de suas operações. A dinâmica da atividade requer atenção e ação tempestiva de seus gestores, a demandar, por conseguinte, informações que auxiliem na observação e possível predição do ambiente.

\subsection{O ambiente regulatório e sua influência na gestão do caixa}

Sendo o ambiente que permeia os bancos altamente regulado e controlado, torna-se necessário compreender, ainda que de maneira geral, como essas forças interferem nos processos de gestão e controle dos fluxos de caixa, moldando e padronizando alguns controles, todavia, ainda assim permitindo que haja margem para que a gestão direcione os processos de acordo com as suas convicções e estratégias. As subseções conseguintes apresentam três assuntos e sua interação com a temática central do presente estudo: os acordos de Basileia, o Fundo Garantidor de Crédito (FGC) e os depósitos compulsórios.

\subsubsection{Os Acordos de Basileia e sua interferência na gestão dos fluxos de caixa}

Grandes crises econômicas e grandes períodos de evolução são marcos de profundas transformações mundiais, mudando a forma com que as pessoas se organizam, pensam e agem. Essas mudanças normalmente ocorrem porque uma crise expõe fragilidades dos entes e do sistema. Sendo assim, os sistemas financeiros das nações, em especial, em função do papel predominante de alicerces e financiadores do desenvolvimento econômico são bastante afetados em momentos de crise. Como consequência desses choques, no ato de repensar o que poderia ser mudado e melhorado, os órgãos e agências reguladoras acabam transformando os controles existentes e impondo novas maneiras de se controlar os sistemas. 
Especificamente no caso do sistema financeiro mundial, segundo Ono (2002), o movimento de desenvolvimento gerado pela globalização dos mercados financeiros, com sistemas cada vez mais complexos e interligados motivou, no final dos anos 80, a discussão pelos países membros do G-10 (Alemanha, Bélgica, Canadá, EUA, França, Holanda, Itália, Japão, Reino Unido, Suécia e Suíça) que objetivou definir os mecanismos gerais de supervisão do sistema financeiro, com foco nos bancos, culminando no primeiro Acordo de Basileia.

O Acordo firmado em 1988, na cidade de Basileia na Suíça, tinha como finalidade estabelecer um nível mínimo de capital necessário para absorver eventuais impactos, dado o perfil de risco dos ativos do banco. Por esse acordo ficou estabelecido um coeficiente entre o patrimônio líquido e os ativos ponderados pelo risco, cujo nível mínimo seria de $8 \%$. Nesse mesmo documento ficaram definidas as regras de ponderação de cada grupo de ativo.

Para que o Acordo pudesse tornar-se efetivo, as nações deveriam aderir às diretrizes propostas pelo G-10 e fazer, destas, regras em seus sistemas financeiros, utilizando para tanto força regulatória. No Brasil, o Acordo de Basileia passou a ser adotado a partir da Resolução BACEN 2.099 de 1994. Ainda assim o coeficiente inicialmente sugerido pelo Acordo de Basileia foi moldado pelo órgão regulador brasileiro, passando de $8 \%$ para $10 \%$ e finalmente para $11 \%$.

Com o passar do tempo percebeu-se que os controles e limites exigidos não eram suficientes para manter a higidez do sistema financeiro mundial. Essa situação ficou mais claramente evidenciada com as crises ocorridas na Ásia e na Rússia nos anos de 1997 e 1998, sendo essa situação um dos principais motivadores do novo Acordo de Basileia firmado em 2001 (ONO 2002), também comumente conhecido como Basileia II.

Nesse novo acordo ficaram estabelecidos três pilares centrais que deveriam nortear a gestão bancária, sendo o primeiro pilar aquele que trata das necessidades mínimas de capital; o segundo pilar aquele que trata da fiscalização do processo de controles internos, devendo esse processo ser criterioso e metodologicamente consistente; e o terceiro e último pilar o que visa aumentar a disciplina do mercado pela ampliação da transparência nas divulgações, tornandoas mais detalhadas e explicativas (ONO, 2002). 
Para Ono (2002), mais especificamente em relação ao primeiro pilar, o novo acordo trouxe mudanças significativas, introduzindo o conceito do risco operacional como ponderador dos ativos em adição ao conceito de risco de crédito e de mercado já existentes. Outro ponto denotado foi a permissão da utilização de um modelo de classificação interna de riscos, denominado Internal Rating Based (IRB), além do modelo padronizado de classificação de riscos recomendado.

O modelo de classificação interna que somente pode ser utilizado se o segundo e terceiro pilares (controles e divulgação) forem atendidos, se baseia na determinação da probabilidade de inadimplência (PD - Probability of Default), no cálculo da perda por inadimplência (LGD - Loss Given Default) e da evidenciação de exposição à inadimplência (EAD - Exposure at Default) (ONO, 2002).

Outro ponto que merece destaque é a securitização de recebíveis, operação que permite a um banco redistribuir seus riscos por meio da transferência legal ou econômica de ativos ou obrigações para outras instituições, quer sejam essas instituições bancos ou não bancos. No Brasil o Acordo de Basileia II foi ratificado pela Resolução BACEN 3.490 em 2007, entrando em vigor apenas em 2008.

Tanto o primeiro acordo em 1988 como o segundo acordo em 2001, afetaram o modo como os bancos gerem os seus recursos introduzindo e consolidando a visão de riscos aliada a resultados, e interferindo, desse modo, também na gestão dos fluxos de caixa, pois além de intermediar recursos, procurando a alternativa mais rentável para aplicações, o banco também passou a atentar-se mais profundamente para o perfil de risco dessa aplicação, sendo a decisão de aplicar ou não num determinado ativo influenciada pelas necessidades de retorno e de caixa, ponderadas pelo risco a ser tomado. Desse modo, os acordos anteriormente citados também têm impacto nas práticas e políticas de gestão dos fluxos de caixa nos bancos em geral, mais especificamente nos bancos brasileiros. No entanto, o terceiro Acordo é o mais importante e impactante para a gestão do caixa.

O fato derradeiro que influenciou o terceiro acordo foi mais um evento de crise, ocorrido nos anos 2008 e 2009 que expôs mais uma vez a fragilidade do sistema financeiro mundial, demonstrando que, mesmo após os esforços dos Acordos de Basileia I e II, ainda existiam pontos críticos que deveriam ser trabalhados. Assim, em 2010 foi firmado um novo Acordo 
de Basileia, sendo que as principais alterações por ele introduzidas foram: o aumento dos percentuais de exigência de capital, podendo o quociente de patrimônio sobre ativos remunerados chegar ao mínimo de 13\%; a construção de colchões de capital para utilização em momentos de crise (conservação e contra cíclico); e a introdução de um padrão global de liquidez, por meio do índice Liquidity Coverage Ratio (LCR), que visa manter um montante de ativos líquidos realizável para cobrir passivos que vencem em até 30 dias, e do índice Net Stable Funding Ratio (NSFR), que visa manter uma relação no mínimo igual entre financiamentos e ativos de longo prazo.

Pelas diretrizes do terceiro acordo, fica claro que a preocupação que dantes residia somente na relação risco, retorno e capital necessário, e apenas se espraiava para a gestão do caixa e dos seus fluxos está se tornando o foco do controle, enaltecendo ainda mais a importância de se conhecer e entender como se delimita, na prática, a gestão do caixa nos bancos brasileiros e sua interação com o contexto que os cerca, inicialmente com este estudo de caso e futuramente com outras pesquisas, sendo essa necessidade importantíssima para uma adequada gestão de recursos, clarificando o interesse regulatório vindouro, além de trazer contribuição sistemática pelo adequado entendimento da dinâmica do caixa, dos seus fluxos e controles, favorecendo a higidez do sistema financeiro como um todo.

\subsubsection{FGC como agente do processo de gestão dos fluxos de caixa}

Dada a importância do sistema financeiro para o desenvolvimento e economia das nações, tornou-se cada vez mais frequente a preocupação em protegê-lo das flutuações e choques advindos das crises econômicas mundiais e ou locais. Da mesma forma que os Acordos de Basileia intentam regulamentar e estabelecer padrões mínimos de capital para cobrir os riscos inerentes das operações financeiras, a existência de um sistema formal de garantias de depósitos tornou-se uma tendência mundial a partir da década de 90, segundo informações do site do Fundo Garantidor de Créditos - FGC (2011). Desse modo, o Brasil buscou alinhar-se a essa tendência.

O FGC é uma instituição privada, formada pela adesão compulsória dos bancos múltiplos, dos bancos comerciais, dos bancos de investimento, dos bancos de desenvolvimento, da Caixa Econômica Federal, das sociedades de crédito, financiamento e investimento, das sociedades 
de crédito imobiliário, das companhias hipotecárias e das associações de poupança e empréstimo. Sua idealização começou a ser concretizada a partir de 1995, pela Resolução 2.197 do Conselho Monetário Nacional (CMN), que autorizou a criação dessa entidade, sendo esta posteriormente regulamentada pela Resolução 2.211/95.

Sucedendo essas resoluções ao longo dos anos vieram as Resoluções 3.040/02, 3.074/03, 3.251/04, 3.400/06, 3.656/08, 3.692/09, 3.793/09, 3.931/10 que consolidaram os objetivos, diretrizes, orientações e eventuais mudanças e transformações dessa instituição. O FGC nasceu tendo como principal objetivo prestar garantia de crédito contra as instituições a ele associadas em caso de decretação de intervenção; liquidação extrajudicial; falência da associada; ou reconhecimento, pelo Banco Central do Brasil, do estado de insolvência da associada.

$\mathrm{O}$ intento dessa instituição é contribuir para proteger o pequeno poupador, promover a estabilidade do Sistema Financeiro Nacional e consequentemente para a prevenção de uma crise bancária sistêmica. A garantia prestada abrange os Depósitos à Vista; Depósitos a Prazo; Depósitos de Poupança, Floatings de Salários e Afins; Letras de Câmbio, Hipotecárias e Imobiliárias. Atualmente seu montante está limitado em $\mathrm{R} \$ 70.000,00$ cujo pagamento por execução da garantia, caso as hipóteses supracitadas ocorram, é efetuado por conta ou por pessoa.

Para efetivar esses intuitos, a capitalização de recursos se dá pela contribuição das instituições associadas, materializada pela aplicação de $0,0125 \%$ ao mês, aplicada ao saldo dos produtos garantidos que foram anteriormente citados, permitindo que o sistema se capitalize em momentos de estabilidade para enfrentar as dificuldades vindouras. De acordo com informações de A. Costa (2006) em trabalho disponibilizado pelo FGC, o papel do Fundo Garantidor de Créditos tem sido fundamental ao longo dos anos, amenizando diversos impactos econômicos.

Para contextualizar a afirmação anterior, A. Costa (2006) traz à tona o momento da criação do plano real que resultou no fim dos ganhos inflacionários costumeiros, fazendo com que ocorressem ajustes e saneamento de ineficiências, antes não evidentes por tais ganhos. Segundo A. Costa (2006), essa situação a que os bancos foram submetidos certamente influenciou a liquidação de cinco instituições em 1996 e seis em 1997, sendo uma grande 
liquidação cujo valor executado de garantia superou os 3 bilhões, precedido de mais algumas liquidações até meados de 2004, cessando este movimento no biênio de 2005 e 2006.

Tantas liquidações consecutivas e de grande montante poderiam ter causado grande estrago no sistema financeiro, no entanto, segundo A. Costa (2006), dadas essas ocorrências, o FGC demonstrou seu importante papel, cumprindo o objetivo esperado, suportando as crises e liquidações, protegendo o pequeno poupador e consequentemente amenizando os efeitos dessas quedas no sistema financeiro e na economia nacional.

Todo esse movimento ainda hoje tem grande ligação com a gestão dos fluxos de caixa das instituições, pois os depósitos garantidos pelo FGC são, em geral, a principal fonte de recursos de uma instituição, e essa necessidade de proteção que por hora traz segurança aos pequenos poupadores e ao sistema financeiro nacional, também tem um custo. Por sua vez, este custo irá onerar a taxa praticada por esses produtos, portanto, um ponto a ser considerado na decisão de incentivo a esses produtos e na desconsideração de um recurso que não é integralmente livre para a instituição em função da sua obrigação com a entidade garantidora.

Desse modo, fica clara a influência desse mecanismo no processo de gestão e controle dos fluxos de caixa, sendo essa possivelmente uma variável adicional que será considerada nas decisões tanto táticas quanto estratégicas, nos processos e controles inerentes da atividade, sendo, assim, mais um exemplo da influência das variáveis contextuais no processo de gestão do caixa.

\subsubsection{Os depósitos compulsórios e gestão e controle dos fluxos de caixa}

Além da garantia dos depósitos provida pelo FGC, os depósitos compulsórios são outro importante ponto que deve ser considerado quando se relaciona o caixa e os depósitos. De forma geral, pode-se dizer que parte do caixa de um banco é destinada a cumprir exigências regulatórias definidas pelos bancos centrais. Especificamente no caso do Brasil, essas exigências são advindas do Banco Central do Brasil (BACEN) em função de sua política monetária e também como uma ferramenta que funciona como um colchão de liquidez. Estas exigências às quais os bancos são submetidos são denominadas depósitos compulsórios. 
Estes depósitos são exigibilidades que devem ser recolhidas ao banco central, dada uma determinada regra de aplicação em relação a cada categoria de depósito, sendo não remunerados ou remunerados por taxas básicas. Diante dessa situação fica claro que, do ponto de vista da instituição financeira, a intenção será de que os depósitos compulsórios sejam minimizados, de forma a liberar recursos para aplicação em ativos mais arriscados, porém mais rentáveis.

A metodologia atual de recolhimentos foi instituída pela Lei n. 4595/64, Lei do Sistema Financeiro Nacional, sendo baseada em reservas defasadas (BARBOSA, 1996). Por esta metodologia existem dois períodos: um para o cálculo, no qual é calculada a média dos depósitos sujeitos ao recolhimento compulsório; e outro de movimentação do compulsório, no qual são realizados depósitos ou saques para manter a média previamente estabelecida. $\mathrm{O}$ primeiro período ocorre em uma semana e o segundo na semana seguinte. Desta metodologia advém a denominação de reserva defasada, em virtude do recolhimento se dar uma semana após o cálculo (BARBOSA, 1996).

Atualmente os depósitos compulsórios incidem basicamente sobre três grandes classes de produtos: recursos à vista, recursos a prazo e depósitos de poupança. Os depósitos compulsórios sobre os recursos à vista não possuem remuneração, os depósitos compulsórios sobre os recursos a prazo são remunerados quase na totalidade pela taxa SELIC e os depósitos compulsórios sobre os depósitos de poupança são remunerados pela mesma taxa paga aos poupadores, que consiste em taxa referencial (TR) $+0,5 \%$ de juros ao mês.

Sobre as classes de produtos supracitadas são aplicadas as alíquotas determinadas pelo BACEN. Estas alíquotas variaram bastante ao longo do tempo de acordo com o momento econômico, com a política monetária e com a política de liquidez pretendidas. Até o início de 2012 a ordem de grandeza das alíquotas, considerando o somatório da alíquota normal e adicional é a seguinte: a maior alíquota incide sobre os recursos à vista; a segunda maior alíquota é a incidente sobre os recursos a prazo, no entanto é pouco maior que a metade da alíquota incidente sobre os recursos à vista; e por último a alíquota sobre os depósitos de poupança.

A base de cálculo dos depósitos compulsórios também é determinada pelo BACEN sendo essa baseada numa lista de Cosifs que representam a classe de depósitos que os contém. 
Depois de calculado o exigível, são efetuadas as eventuais deduções permitidas pelo BACEN. As deduções são parte de um mecanismo de leve afrouxamento utilizado pelo governo, em períodos nos quais esta medida se faz necessária. Por exemplo, na época da bolha imobiliária norte-americana de 2008, as carteiras de crédito adquiridas de bancos de pequeno porte eram tidas como dedutíveis para efeito do cálculo dos depósitos compulsórios sobre o depósito a prazo.

Por fim, será recolhida ou liberada a diferença entre o exigível calculado e recolhido no período anterior e o exigível calculado no período corrente. O BACEN também estabelece punições por descumprimento das normas de recolhimentos de depósitos compulsórios. Atualmente as penalidades consistem em multa de aplicação de taxa SELIC mais 30\% a.a. para saldo abaixo do mínimo permitido, aplicação de taxa SELIC mais $45 \%$ a.a. para saque a descoberto, e aplicação de taxa SELIC mais 30\% a.a para deficiência do saldo médio. A aplicação das taxas incide sobre o montante da diferença que ocasionou a penalidade.

Assim como o FGC, os depósitos compulsórios são limitadores da liquidez disponível e devem ser considerados nas práticas e decisões acerca dos fluxos de caixa, merecendo atenção e controle, de modo que sejam minimizados e considerados em todas as decisões acerca do caixa, suas fontes e seus usos. Dessa forma, os órgãos reguladores são agentes atuantes na formação e transformação do caixa, devendo, portanto, ser considerados e equacionados, no processo de gestão e controle dos fluxos de caixa.

\subsection{Histórico dos bancos brasileiros: relatos e estatísticas}

\subsubsection{Um breve relato histórico acerca do mercado bancário brasileiro}

Com o objetivo de enriquecer a contextualização deste estudo, faz-se necessário tecer um breve relato histórico sobre a evolução do mercado bancário brasileiro, partindo do século XIX até os dias atuais, de modo a elucidar os principais acontecimentos econômicos que moldaram o nosso sistema financeiro e fizeram com que os bancos brasileiros se encontrem no seu atual estágio evolutivo, delineando características que podem ser importantes para a compreensão dos processos de gestão e fluxos de caixa dessas instituições em geral e especificamente da instituição que será analisada neste trabalho. Baseando-se no trabalho de 
F. Costa (2008) que secciona a história dos bancos brasileiros em seis estágios, é possível descrever as principais características de cada um deles, entretecendo-as com informações relevantes de outros estudos.

Para F. Costa (2008), o primeiro estágio ocorreu entre 1808 e 1921, iniciando-se na primeira fundação do Banco do Brasil, passando também pela sua transformação em autoridade monetária. Esse estágio é caracterizado pela força do ouro como moeda motora da economia brasileira.

O segundo estágio, marcado pela primeira e segunda guerras mundiais, bem como pela crise de 1929, de acordo com F. Costa (2008), ocorreu entre os anos de 1921 e 1945, sendo delineado pela criação da moeda bancária, pela origem dos principais bancos como a Casa Bancária Moreira Salles de Poços de Caldas (que futuramente se chamaria Unibanco) e o Banco Lavoura de Minas Gerais (que futuramente seria denominado Banco Real). Para F. Costa (2008), a propensão ao surgimento de diversos bancos na época se deu em função das fracas barreiras de entrada, entre elas o pequeno volume de capital inicial necessário; como também pela acessibilidade à tecnologia bancária. Outros destaques desse período são a reforma bancária que resultou na criação de uma câmara de compensação para cheques e numa carteira de redescontos no Banco do Brasil para descontar títulos de outros bancos, o fim do ouro como moeda padrão, a ampliação da rede bancária e as primeiras exigências de reserva no varejo.

O terceiro estágio ocorrido entre 1945 e 1964, de acordo com F. Costa (2008), traz como determinantes a exigência de reservas bancárias fracionárias sobre os depósitos; a transferência de depósitos como meio comum de troca; a aceitação dos cheques pela rede comercial; e a expansão da rede bancária em nível nacional.

Nessa mesma época, segundo F. Costa (2008), apenas três linhas de financiamento estavam disponíveis: o autofinanciamento via capitalização interna das instituições e o financiamento quer seja por recursos externos quer seja por recursos públicos. Em meados de 1952 surge o Banco Nacional de Desenvolvimento (BNDE) que tinha como função gerir o Fundo de Aparelhamento Econômico, contando com dotação de recursos públicos e recursos externos (posteriormente extintos). O BNDE financiou grandemente os setores de transporte e energia e mais tarde o setor siderúrgico, sendo esse o principal suporte ao desenvolvimento 
econômico, em razão da retração dos mercados de capitais e de crédito que eram pouco desenvolvidos.

Segundo F. Costa (2008), o mercado de crédito era basicamente formado pelo desconto de duplicatas, pelo financiamento de capital de giro efetuado pelos bancos comerciais, pelo financiamento de bens duráveis pelas indústrias e pelos empréstimos concedidos pelas instituições financeiras públicas, ou seja, o mercado de crédito brasileiro, na época, era bastante rudimentar e embrionário. Nesse mesmo período, F. Costa (2008) afirma que a Superintendência da Moeda e do Crédito (SUMOC) dividia com o Banco do Brasil a alcunha de autoridade monetária no país, e que o mercado de títulos de dívida era inibido pela alta inflação.

De acordo com o mesmo autor (2008), o quarto estágio inicia-se no período do golpe militar em 1964 e perdura por trinta anos. Nesse período predominou a alta inflação que trouxe ganhos consideráveis aos bancos que aplicavam em ativos corrigidos e suportavam suas operações em depósitos e floatings de custo zero, passando por diversas fases. A primeira em que se tentou implantar o modelo norte-americano no Brasil, freando os velhos banqueiros e trazendo oportunidades aos novos entrantes; outra que consistiu na incorporação dos novos entrantes falidos pelos velhos banqueiros, dando início ao processo de concentração e multilateralização; e a última que consistiu na liberalização do mercado financeiro, na abertura do mercado nacional aos capitais externos e na formalização dos bancos múltiplos.

O referido autor (F. COSTA, 2008) ainda afirma que esse período também abarcou a Lei 4.728/65 que oficializou a regulação acerca do mercado de capitais e estabeleceu medidas com intuito de desenvolvê-lo. Esta lei abrangia formalmente instituições que já figuravam no sistema financeiro nacional, como as corretoras e distribuidoras de títulos e valores mobiliários, os bancos de investimento, dos quais muitos nas décadas seguintes se associariam aos bancos comerciais formando os conglomerados financeiros, que seriam formalizados pela figura do banco múltiplo, em 1988 pela resolução 1524 do Banco Central.

Um banco múltiplo é formado pela associação de bancos comerciais, de investimento, de desenvolvimento, e sociedades de crédito, com personalidade jurídica própria, nos termos da legislação em vigor. Podem ser privadas ou públicas e realizam as operações ativas, passivas 
e acessórias das diversas instituições financeiras, por intermédio das seguintes carteiras: comercial, de investimento e ou de desenvolvimento (sendo que esta somente poderá ser operada por banco público), de crédito imobiliário, de arrendamento mercantil e de crédito, financiamento e investimento, sendo que o banco múltiplo deve ser constituído com, no mínimo, duas carteiras, sendo uma delas, obrigatoriamente, comercial ou de investimento, e ser organizado sob a forma de sociedade anônima.

Segundo Gallo (2002) não menos importante para esse período foi a criação da Comissão de Fusão e Incorporação de Empresas (COFIE) em 1971 pelo Decreto Lei ${ }^{\circ} 1.182$, com o intuito de examinar os processos de reavaliação, fusão e incorporação de empresas em atividade no país, nos casos em que for pleiteada a concessão de benefícios fiscais, de modo a estimular as operações de fusão, incorporação e união entre empresas. Entretanto, Gallo (2002) afirma que este mesmo decreto lei requeria algumas medidas especiais quando as empresas envolvidas eram instituições financeiras e sociedades de capital aberto, como a publicação nos jornais de grande circulação dos termos em que se realizariam as operações envolvendo, e a necessidade de se ouvir previamente o Banco central.

A COFIE funcionou até dezembro de 1979 e atuou num período onde predominaram processos de fusão e incorporação no qual empresas consideradas mais fortes absorviam empresas consideradas mais fracas. Neste período como as instituições financeiras eram autorizadas a operar pela emissão da carta-patente pelo BACEN, este instrumento era um atrativo para as fusões, dado que adquirir uma instituição, muita das vezes significava primeiramente adquirir sua carta-patente. Outro importante atrativo era o benefício fiscal concedido pelo governo, por meio da análise realizada pela COFIE. Estas ações também contribuíram para mais um acontecimento importante para o quarto estágio que para $\mathrm{F}$. Costa (2008) foi a mudança de liderança entre os bancos existentes, pois Itaú e Bradesco ultrapassaram Unibanco e Real, distanciando-se pelas incorporações e também pela liderança tecnológica.

Esse estágio também contempla a formalização do Banco Central do Brasil (BACEN). De acordo com Corazza (2006), o Brasil foi um dos últimos países do mundo a formalizar a criação do seu banco central, tendo o processo de criação durado cerca de 20 anos desde a fundação de seu primeiro embrião em 1945, a SUMOC, que dividia as responsabilidades com o tesouro e com o Banco do Brasil, conforme supracitado no terceiro estágio, até a sua efetiva 
criação em 1964. Porém, segundo Corazza (2006), foram necessários mais 24 anos para que se tornasse efetivamente a autoridade monetária unívoca, em 1988. Essa situação de entraves ocorria em função do conflito de interesses entre diversos grupos como agronegócio, setor industrial e o próprio governo.

Já o quinto estágio, de acordo com F. Costa (2008), é delimitado pelos anos de 1994 e 2002, sendo marcado pelo impacto da estabilização inflacionária sucedida pela crise bancária com a liquidação de grandes bancos privados nacionais; muitas privatizações dos bancos estaduais; reestruturação dos bancos federais; desnacionalização e concentração; grandes alterações nas políticas econômicas a partir de 1999 com a adoção de câmbio flutuante, metas para inflação e para superávit primário; início da utilização de empréstimos pré-estabelecidos e ou contratados. A despeito dessas medidas, segundo F. Costa (2008), a evolução do crédito foi ínfima nesse período.

Durante o quinto estágio, segundo Maia (2003) a ameaça de falência de algumas instituições bancárias consideradas "too big to fail" exigiu do BACEN uma nova política com a criação do o Programa de Estímulo à Reestruturação e ao Fortalecimento do Sistema Financeiro Nacional (PROER), a fim de evitar a quebra de confiança no sistema bancário. De acordo com a Maia (2003) este programa baseou-se em dois princípios gerais: a preservação da estabilidade do sistema de pagamentos via garantia dos depósitos dos aplicadores; e a penalização das más políticas bancárias, via transferência do controle acionário das instituições socorridas pelo programa. Os bancos problemáticos foram divididos em "banco bom" e "banco ruim", o primeiro depois de sanado, sendo adquirido por outra instituição bancária quer seja esta nacional ou estrangeira, e o segundo sendo liquidado pelo Banco Central. Ainda de acordo Maia (2003) ao todo, as operações PROER somaram R $\$ 20,4$ bilhões, ou aproximadamente 2,7\% do PIB médio de 1995 a 1997.

De acordo com Vieira (2007) na mesma época destacou-se também o Programa de Incentivo à Redução da Presença do Setor Público Estadual na Atividade Financeira Bancária e a Privatização de Instituições Financeiras Estaduais (PROES) que tinha por finalidade a liberação de recursos aos estados, pela privatização de suas instituições financeiras. Vieira (2007) afirma que graças ao PROES algumas instituições foram simplesmente extintas, outras privatizadas sob a interveniência do Estado, que atuava com controlador e avalista. A 
contrapartida declarada aos estados para compensar a perda de suas instituições financeiras, foi a possibilidade de estabelecer agências de fomento, que segundo Vieira (2003) apesar possuir importante papel no desenvolvimento regional não podiam captar recursos no mercado. De acordo com o estudo de Vieira (2007) o montante de financiamentos do PROES alcançou cerca de 74 bilhões de reais.

Contudo, tanto o movimento de fusões ocorridas no quinto estágio, como o movimento de desnacionalização, contribuíram não somente para injetar investimento na economia brasileira, como também para acirrar a concorrência no mercado local com a presença de novos entrantes, estimulando o ganho de eficiência pelo aumento da concorrência. Junior e De Paula (2009) em seu estudo tentam elucidar o ganho de eficiência pelo movimento de fusões e aquisições ocorridas a partir da década de 90. Seu trabalho analisa 6 bancos, sendo três de controle nacional e três de controle estrangeiro por meio da técnica de Análise Envoltória de Dados (DEA). Pelos achados, os bancos nacionais iniciaram o período com eficiência menor que os estrangeiros, porém por ocasião das fusões apresentaram ganho de eficiência, igualando o nível dos estrangeiros que, por sua vez, perderam eficiência com as fusões, demonstrando que o movimento de fusões auxiliou os bancos nacionais a concorrerem globalmente com os entrantes estrangeiros no mercado nacional.

O sexto e último estágio ocorrido entre 2003 e 2006, segundo F. Costa (2008), é marcado pela popularização dos serviços bancários, com maior facilidade de acesso da população aos bancos e ao crédito, criação dos correspondentes bancários e das contas simplificadas, bem como ampliação da rede de caixas eletrônicos. Outro ponto a destacar trata-se da crescente disseminação da utilização de meios eletrônicos de relacionamento bancário através da internet, que auxiliou na popularização supracitada, trazendo comodidade e agilidade para os clientes que possuem livre acesso à internet, facilitando as transações bancárias por esse meio.

Os parágrafos anteriores contextualizam de forma geral a evolução dos bancos brasileiros, passando pelos principais acontecimentos e características presentes em cada época, desse modo contribuindo para enriquecer o entendimento acerca do universo de instituições em que está contido o objeto deste estudo, um banco. A próxima seção complementa os relatos históricos com estatísticas acerca dos bancos brasileiros ao longo do tempo. 


\subsubsection{O mercado bancário em números: estatísticas do BACEN - dos primórdios}

\section{ao ano 2000}

Para enfatizar ainda mais o movimento ocorrido entre os estágios quatro e cinco da subseção anterior, utilizam-se estatísticas do BACEN, dispostas de maneira lógica e ordenada na sequência desse trecho de modo a trazer contribuições ratificadoras sobre o movimento ocorrido nesse ínterim. Estas contribuem para compreendermos como o mercado bancário se desenvolveu nos últimos anos e como é composto o perfil das instituições que operam nesse mercado, reforçando também a contextualização do ambiente que permeará as análises acerca dos processos de gestão e controle de caixa do banco brasileiro que será analisado neste estudo.

Optou-se por utilizar as estatísticas que se estendem até 2000, por não haver base de dados atual com tanta completude e riqueza de informações que pudessem demonstrar os movimentos ocorridos no mercado bancário brasileiro, abdicando de uma análise que se estendesse até um período mais contemporâneo, para traçar um perfil histórico mais aprofundado.

As estatísticas se baseiam na comparação entre dois grandes períodos: até 1988 e após 1988. No segundo período, pós-regime militar, destacam-se a evolução do capital estrangeiro e a redução dos bancos públicos, materializada pela política de privatizações. Nesse mesmo período, a configuração do sistema financeiro sofreu profunda transformação com a Resolução 1.524 de 1988, passando os participantes do mercado a possuir múltipla atuação, oferecendo grande gama de serviços financeiros em detrimento do escopo restrito de atuação que dantes possuíam. As estatísticas apresentadas na sequência demonstrarão as grandes transformações do sistema financeiro nacional, quando comparados os períodos antes e após 1988 .

Para caracterizar essa informação, as estatísticas presentes nos gráficos 1 e 2 abaixo ilustrados apresentam a quantidade de bancos existentes, seu ano de entrada, seu perfil de controle e o tipo de instituição até 1988, ano em que o BACEN entra definitivamente em ação e ano de uma profunda reforma no Sistema Financeiro Nacional (SFN). Conforme demonstrado abaixo no gráfico 1, até 1988, havia um equilíbrio entre bancos públicos, bancos privados de controle 
nacional e bancos privados de controle estrangeiro, sendo a quantidade de cada um 29, 46 e 26 respectivamente.

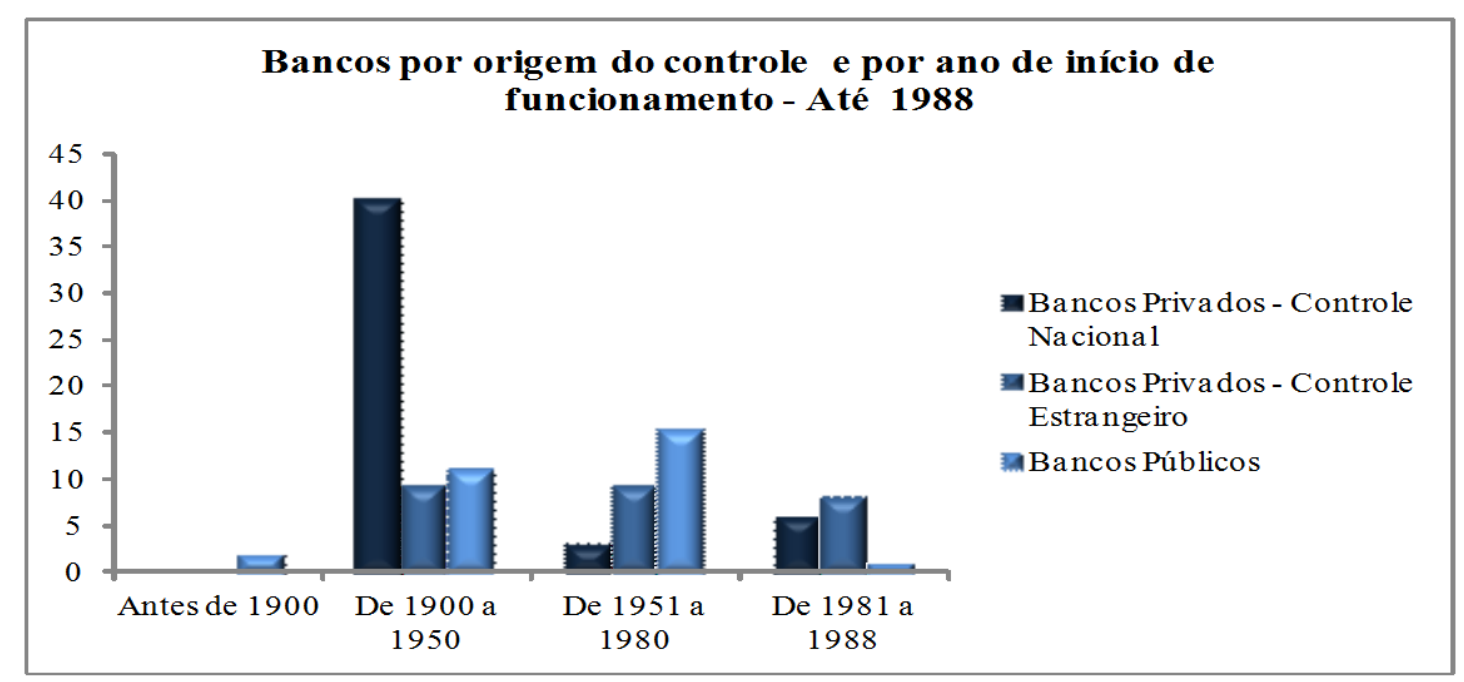

Gráfico 1 - Banco por origem do controle e por ano de início de funcionamento FONTE: Banco Central do Brasil, 2000

O surgimento de bancos privados de controle nacional está concentrado principalmente entre 1900 e 1950, enquanto o surgimento de bancos públicos e privados de controle estrangeiro está espraiado pelo período. Já a especificidade das instituições fica clara no gráfico 2, a seguir, que demonstra que a maioria das instituições eram única e exclusivamente bancos comerciais (100 das 104 instituições existentes até 1988).

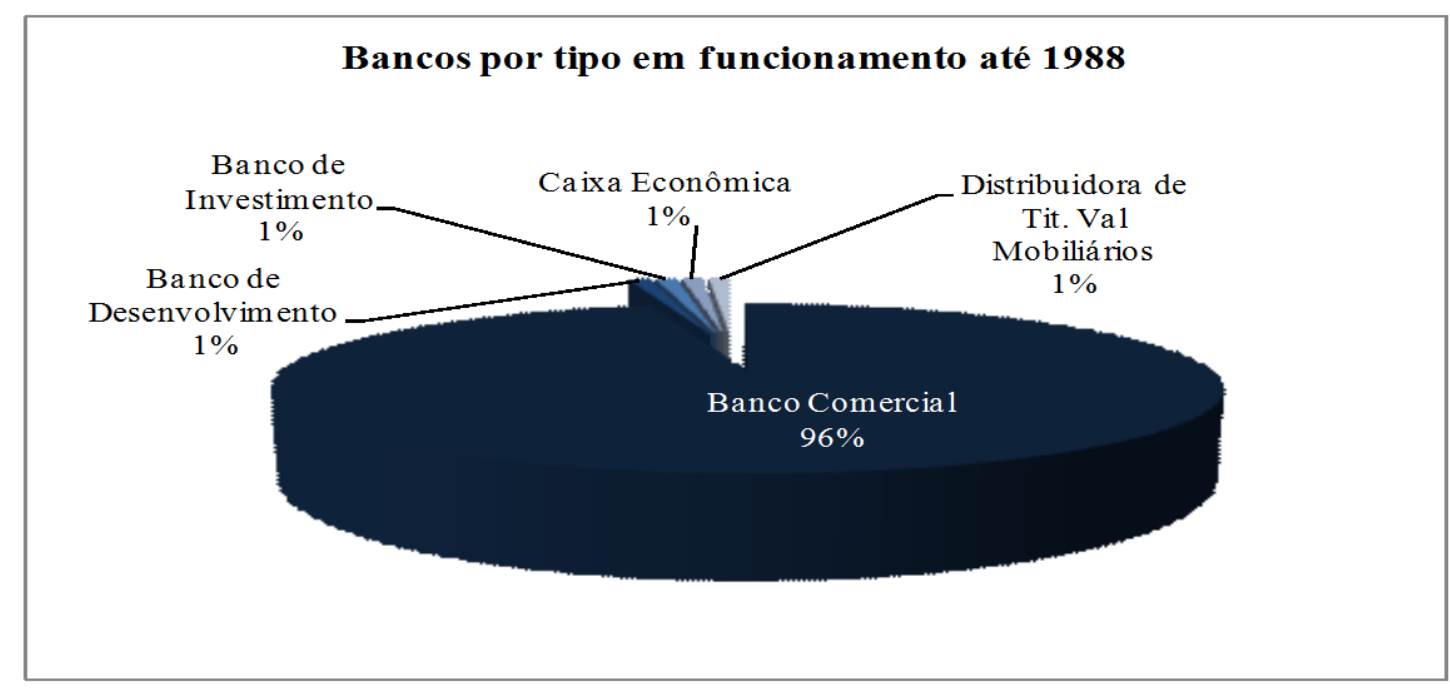

Gráfico 2 - Bancos por tipo em funcionamento FONTE: Banco Central do Brasil, 2000 
Logo abaixo, no gráfico 3, é demonstrado o que ocorreu, até o ano 2000, com parte das instituições que estavam em funcionamento em 1988 em razão dos processos de desnacionalização, movimento de concentração, movimento inflacionário, e a política de privatizações dos bancos públicos ocorridas no período.

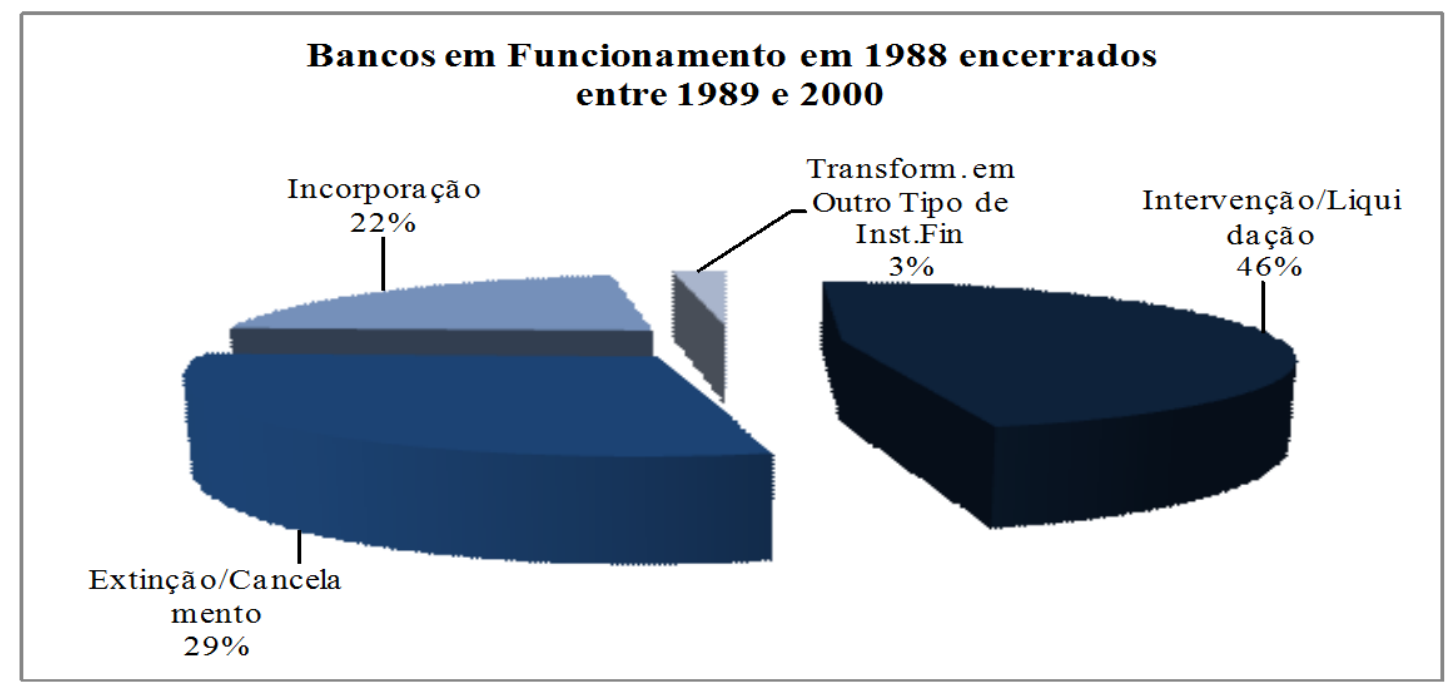

Gráfico 3 - Bancos em funcionamento em 1988 encerrados nos anos seguintes FONTE: Banco Central do Brasil, 2000

O gráfico acima mostra o reflexo do fim dos ganhos inflacionários em 1994, descobrindo a ineficiência operacional de muitas instituições e ocasionando um grande número de intervenções e liquidações (19), bem como de extinções e ou cancelamentos (12). A movimentação é completada por 9 incorporações e 1 transferência de controle que demonstram um pouco da tendência concentradora que despontava como tônica para o mercado.

No gráfico 4 que será demonstrado a seguir, ficará claro também o aumento da diversidade do tipo de instituições atuantes, tanto do mercado de crédito como no embrionário mercado de capitais, oferecendo, portanto, uma grande gama de serviços financeiros de maneira individual, ou ainda de maneira integrada, pela figura do banco múltiplo que abarca diversas funções em um único conglomerado.

A posição pós 1988 é bastante diferente da posição pré 1988. Até 1988 as instituições denominadas bancos comerciais representavam $96 \%$ do total dos bancos e, no período pós 
1988 até 2000, essa participação cai para $47 \%$ se considerados também os bancos múltiplos na categoria comercial. Os bancos de investimento que representavam por volta de $1 \%$ do total das instituições até 1988 ampliaram sua representatividade no período pós 1988 até 2000 alcançando cerca de $10 \%$.

Outros tipos de instituições que até 1988 existiam, porém não de maneira estruturada e regulamentada, passaram a integrar formalmente o quadro geral, entre elas: Sociedade de Arrendamento Mercantil; as Sociedades de Crédito Imobiliário; as Sociedades de Crédito, Financiamento e Investimento; as Corretoras de Títulos e Valores Mobiliários; e as Distribuidoras de Títulos e Valores Mobiliários.

As duas últimas formas societárias demonstram o crescimento do mercado de capitais que passou a representar 27\% do total das instituições no período pós 1988 até 2000. Observa-se também quase $100 \%$ de aumento no número de instituições, passando de 104 até 1988 para 191 no período pós 1988 até 2000 .

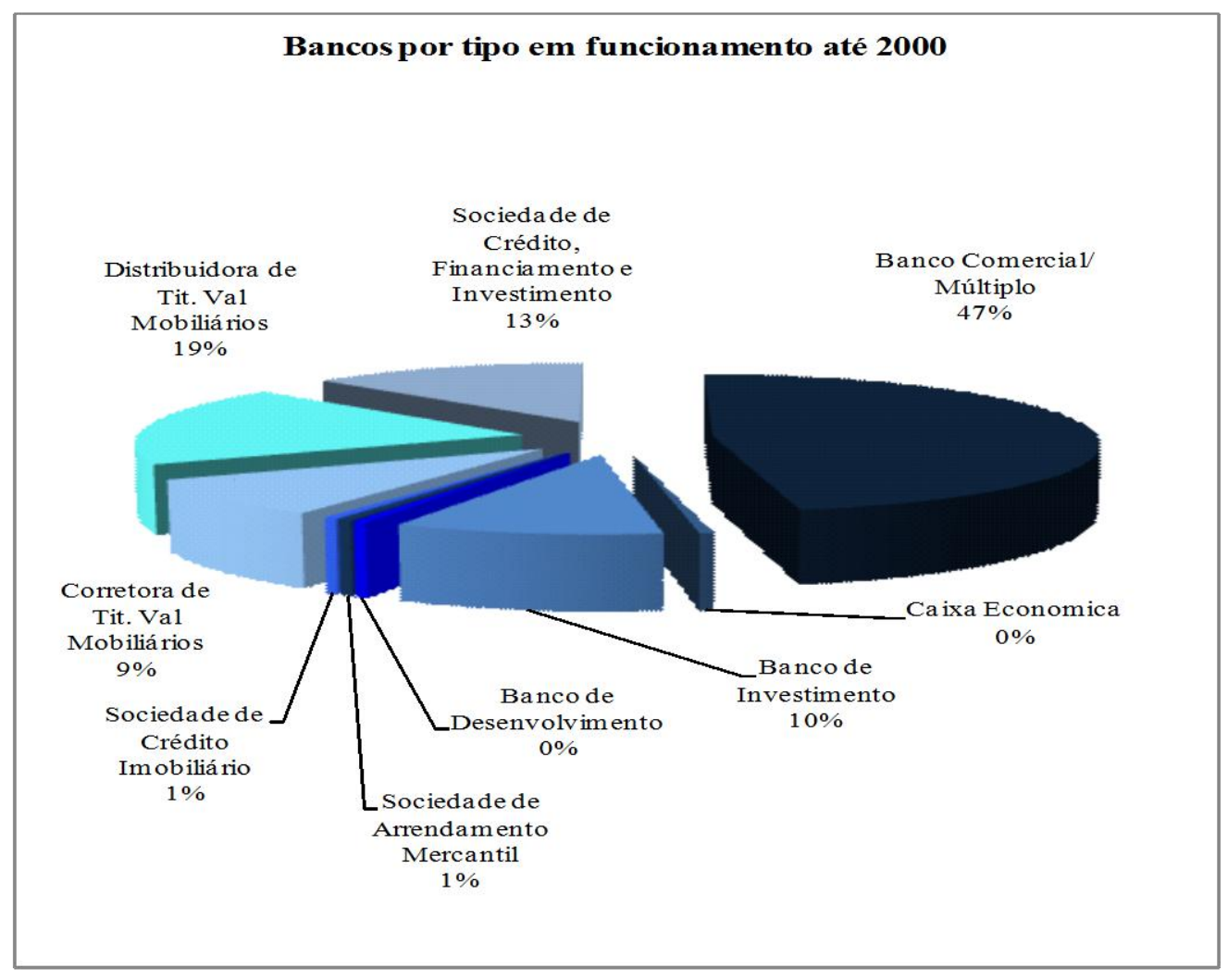

Gráfico 4 - Bancos por tipo em funcionamento até 2000 FONTE: Banco Central do Brasil, 2000 
Outro ponto a ressaltar é a crescente participação de bancos privados de controle estrangeiro com menos tempo de funcionamento, aproximando-se dos bancos privados de controle nacional e dos bancos públicos que detinham a liderança do setor e que possuíam mais de 50 anos de funcionamento na época. Como demonstrado no gráfico 5 , do total de ativos do mercado no período pós 1988 até 2000, os bancos privados de controle nacional detinham $43 \%$; contra $33 \%$ dos banco privados com controle estrangeiro, sendo que, desses, $21 \%$ eram de instituições com menos de 20 anos de funcionamento; e $24 \%$ dos bancos públicos.

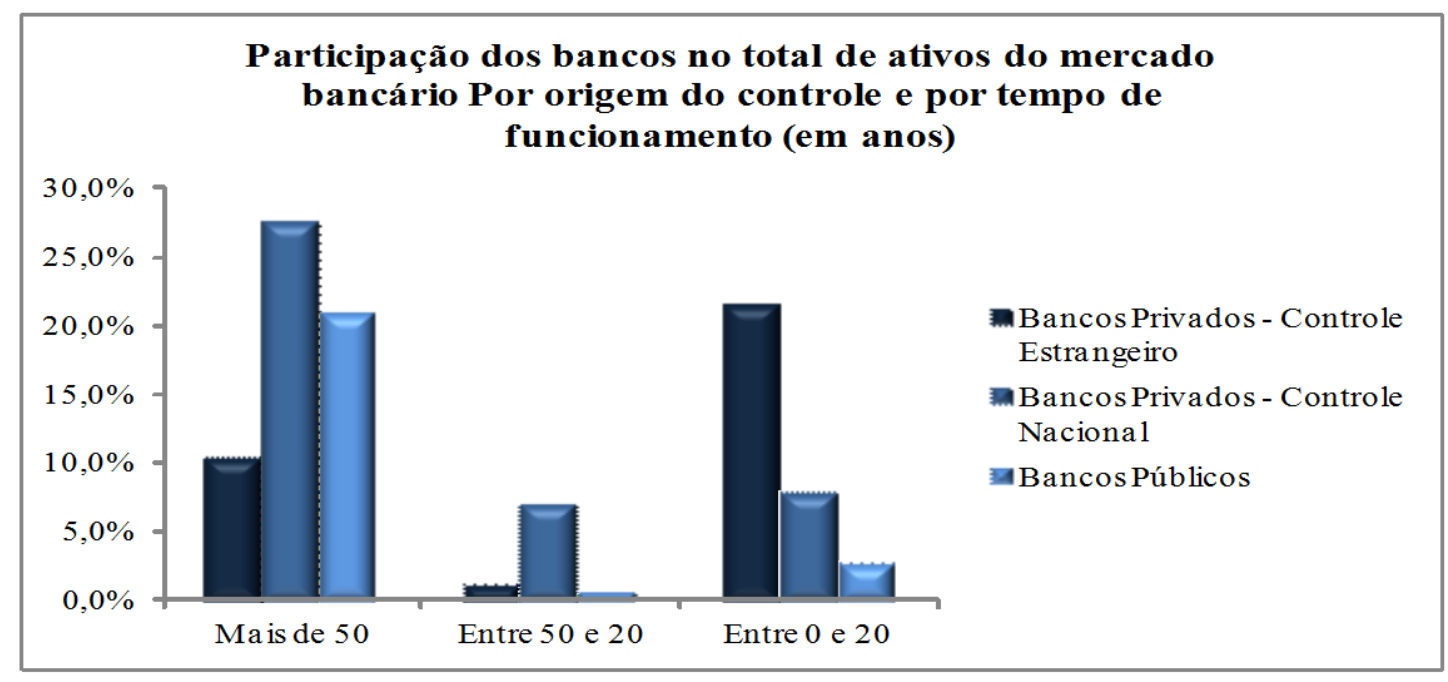

Gráfico 5 - Participação e concentração bancária FONTE: Banco Central do Brasil, 2000

As tendências de concentração, de desnacionalização e de privatização ficam mais claras nos dois últimos gráficos (6 e 7). A concentração aumenta a partir do Plano Real, sendo os vinte maiores bancos detentores de cerca de $75 \%$ do total de ativo no mercado bancário em 1995 contra quase $80 \%$ no período pós 1988 até 2000, conforme demonstrado no gráfico 6.

Já a evolução da desnacionalização e a privatização ficam mais clara no gráfico 7 que aponta a queda de $33 \%$ para $24 \%$ de participação dos bancos públicos, em detrimento do crescimento da participação dos bancos de controle estrangeiro de cerca de $10 \%$ para $33 \%$, abocanhando também parte do mercado dos bancos de controle nacional na comparação dos períodos. 


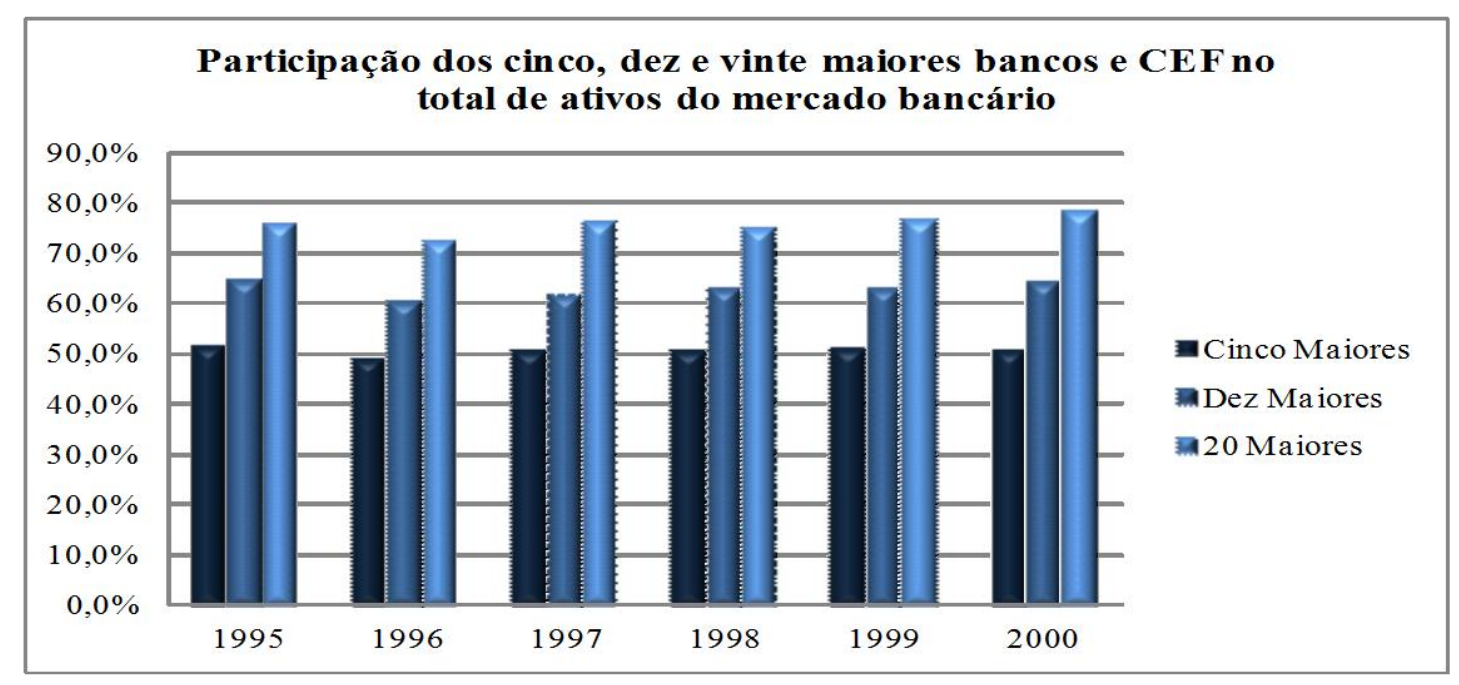

Gráfico 6 - Participação dos top cinco, dez e vinte FONTE: Banco Central do Brasil, 2000

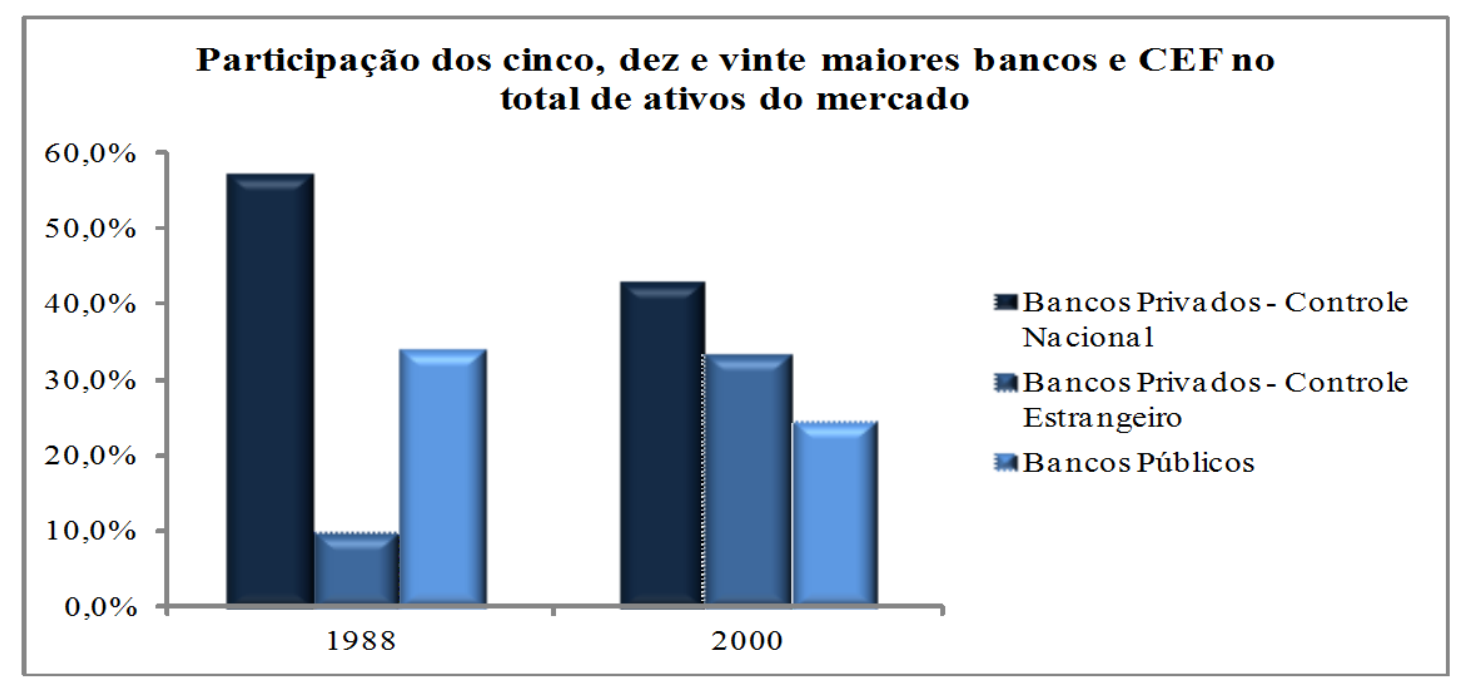

Gráfico 7 - Participação por Origem de Controle FONTE: Banco Central do Brasil, 2000

Desse ponto em diante a tônica não foi muito diferente, com a redução gradativa da participação de bancos públicos no mercado bancário, principalmente em se tratando de bancos regionais, sendo a maioria desses, alvo de privatizações, passando predominantemente a ser controlados pela iniciativa privada, quer seja ela nacional ou estrangeira, como o caso da compra do Banespa pelo Banco Santander Brasil, ligado à matriz espanhola. O principal banco público federal, o Banco do Brasil, se fortaleceu na busca da retomada da liderança, adquirindo outros bancos e aproveitando momentos de crise, como a de 2008, para expandir sua carteira de ativos. 
Essa mesma crise que afetou mais fortemente países desenvolvidos, como os EUA e os países participantes da zona do Euro, acabou reduzindo em parte o ímpeto do crescimento dos bancos de controle estrangeiro no Brasil. As fusões e o movimento de concentração continuaram fortes com destaque para a mega fusão entre os gigantes Itaú e Unibanco. Sendo assim, a tendência de concentração no mercado bancário e de diversificação de serviços prestados por um único ente, ou seja, a atuação múltipla de bancos gigantes permanece até os dias atuais. Os bancos pequenos e médios acabam atuando em nichos econômicos, quer seja no financiamento a instituições de um ramo específico, quer seja no suporte a clientes de alta renda para fins de investimento.

A seção seguinte trata da gestão de riscos aplicada aos bancos, com ênfase no risco que está diretamente relacionado à gestão dos fluxos de caixa. A visão da gestão focada em riscos poderá contribuir bastante para este trabalho.

\subsection{Gestão de riscos e liquidez}

\subsubsection{Riscos e liquidez: conceitos e características gerais}

A gestão bancária frente às características do segmento possui diversas peculiaridades. Uma forte vertente da gestão bancária e que já está presente também em outros setores é a gestão de riscos. Para Bessis (1998), a grande utilização da gestão de riscos nos bancos se dá principalmente pela sua volatilidade, em razão de sua principal função ser a otimização da alocação de recursos na economia atuando como intermediadores, deste modo, expondo-se a diversas fontes de incerteza como taxas de juros, taxas de câmbio, solvência dos clientes, malha tributária, entre outros fatores que necessitam de monitoramento e gestão. Muitos destes fatores estão extremamente ligados ao cenário macroeconômico e às políticas praticadas pelo país onde o banco está estabelecido.

Ainda segundo Bessis (1998), o risco é o impacto na rentabilidade causado por diversas fontes de incerteza, ou seja, é impacto nas operações de uma instituição, causado por diversas fontes exógenas e ou endógenas, que podem levá-la à insolvência se não forem devidamente controladas e dirimidas. No entanto, o próprio conceito de rentabilidade está fortemente relacionado à administração de riscos, pois assumir riscos é uma condição necessária para 
alcançar rentabilidade futura (MARKOWITZ, 1952). Desta forma, a gestão de riscos consiste na gestão das incertezas, antevendo e reduzindo impactos, tornando-os controláveis e remediáveis, sendo esta função essencial para a solvência, boa saúde financeira e otimização dos resultados dos bancos em função da natureza de suas operações.

Para Bessis (1998), os riscos a que as instituições financeiras estão expostas podem ser classificados em: risco de crédito; risco de taxa de juros; risco de mercado; risco de câmbio; risco operacional; risco de solvência, o mais sistêmico; e o risco de liquidez.

O risco de taxa de juros é o risco do declínio de lucros em função de movimentação das taxas de juros, enquanto o risco de crédito segundo a Resolução 3721/2009 do BACEN, é definido como a possibilidade de ocorrência de perdas associadas ao não cumprimento pelo tomador ou contraparte de suas respectivas obrigações financeiras nos termos pactuados, à desvalorização de contrato de crédito decorrente da deterioração na classificação de risco do tomador, à redução de ganhos ou remunerações, às vantagens concedidas na renegociação, e aos custos de recuperação.

O risco de mercado é o risco de desvios adversos do valor de mercado dos instrumentos financeiros quando da liquidação destes, enquanto o risco de câmbio é o risco ocasionado por flutuações no câmbio, ocasionando perdas em ativos indexados na moeda em questão. O risco operacional é o risco de mau funcionamento dos sistemas de informação, sistemas de relatórios e das regras de controle interno, enquanto o risco de solvência é o risco de default do banco. Este último tem sido alvo de ações regulatórias como dos Acordos de Basileia, que visam exigir que o banco possua adequado nível de capital para absorver perdas advindas de exposição a outros tipos de riscos.

Por fim, o risco de liquidez, sendo este o mais importante para este estudo, que, para Bessis (1998), consiste no maior risco a que os bancos estão expostos, é definido, na concepção do autor, como a capacidade de cumprir suas obrigações de curto prazo (passivos) por meio do sacrifício de recursos (ativos) de que dispõe. A liquidez está relacionada com a obtenção de fundos a um custo razoável e está sujeita a diversas variáveis como volume de transações, prazos de ativos e passivos, sua maturidade, nível de taxa de juros, e negociação com contrapartes, por exemplo. 
O risco de liquidez tem forte correlação com a gestão e controle do caixa, uma vez que ambos estão focados em equilibrar a oferta e demanda de recursos financeiros, refletida no saldo e nos fluxos de caixa. Quaisquer desencaixes repentinos, mesmo que momentâneos, podem significar perdas significativas de resultados, quer seja pela subaplicação de recursos, caracterizada pela sobra de caixa ou aplicação dos recursos à taxa mais baixa do que desejado ou pela superaplicação de recursos caracterizada pela escassez de caixa e eventual captação emergencial à taxa mais alta do que desejado.

A administração do risco de liquidez possui o intuito de gerir o chamado gap de liquidez, definido pela diferença entre ativos e passivos, atentando para as maturidades, futuras necessidades e eventuais contingências, sugerindo muitas vezes a manutenção de um colchão de liquidez para absorver estas possíveis flutuações, sendo este denominado de caixa e representado por moeda corrente ou ativos de altíssima liquidez no mercado, a exemplo dos títulos públicos.

O gap deve ser gerido e projetado, ou seja, administrado tanto no curtíssimo prazo como no curto e longo prazo, por meio da gestão do gap estático, que consiste na gestão evolutiva de ativos e passivos já existentes, como por meio da gestão do gap dinâmico que consiste na gestão tanto dos ativos e passivos já existentes como dos novos ativos e passivos advindos de projeções das áreas comerciais (BESSIS, 1998). Este gap pode ser gerido mensalmente, semanalmente, diariamente, de acordo com a necessidade da instituição.

Da chamada administração do gap advém a gestão de liquidez que consiste no contínuo processo de captar novos recursos no caso de déficit e ou reaplicar os recursos existentes em caso de superávit de recursos. Para tanto, ela se utiliza de diversas práticas como o "casamento do caixa", também denominado de matching, que ocorre quando a instituição consegue igualar as maturidades de alguns de seus ativos e passivos; utilização de múltiplos cenários; para considerar norteamentos e condições econômicas diversas e de modelos de simulação para pré-pagamentos de empréstimos; definição de premissas para depósitos sem maturidade e utilização de estatística para depósitos contingenciais; definição de política para reinvestimento dos fluxos de juros recebidos, entre outras práticas (BESSIS, 1998). 
Outro ponto a destacar é que a gestão de liquidez também está associada ao conceito de custo da liquidez, que é o custo de se manter e ou obter fundos necessários para atender necessidade de liquidez. O custo de liquidez dos bancos normalmente está associado à manutenção de uma margem de segurança, ou seja, um caixa mínimo para absorver eventuais flutuações, também chamado de colchão de liquidez.

Como se pode observar no esquema a seguir que representa a afirmação supracitada, a região amarela representa a margem de segurança, cujo custo de manutenção é o custo de liquidez. Quanto menor for a região amarela, desde que esta cumpra as obrigações de curto prazo e possíveis obrigações emergenciais, maior será a capacidade de aplicação em ativos creditícios e consequentemente maior será a lucratividade do banco, ou seja, pela lógica da operação financeira, quanto menos recurso for necessário manter em caixa, melhor será, pois desta forma haverá mais recursos livres à disposição da instituição para serem oferecidos a clientes por meio de produtos financeiros.

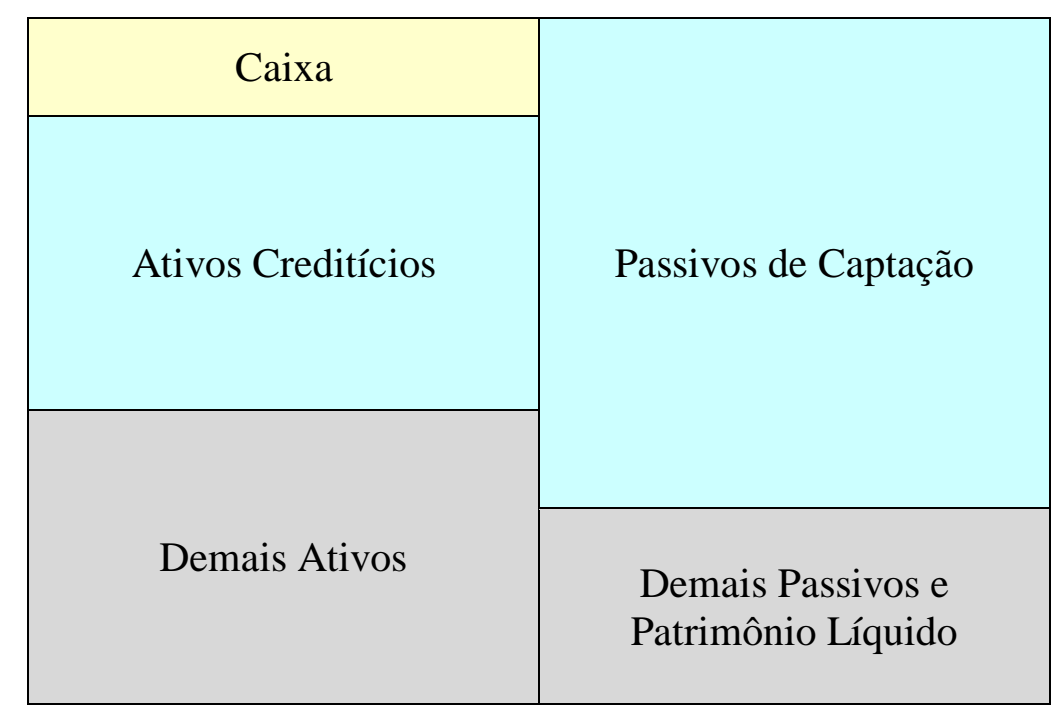

Ilustração 1 - Dinâmica do caixa no banco

No entanto, para gerir a liquidez, além de considerar o risco de liquidez, o banco deverá considerar seu inter-relacionamento com outros riscos, sendo fundamental o entendimento destas relações para sua adequada gestão. Por exemplo, a maioria dos saldos de ativos e passivos de um banco está indexada a uma taxa de juros e, portanto, o risco de taxa de juros pode afetar o risco de liquidez. Do mesmo modo, o default dos clientes tomadores de empréstimos pode reduzir o volume dos recursos, sendo, portanto, o risco de liquidez afetado pelo risco de crédito. 
Esta situação induz a necessidade de gerir os demais riscos para que seu impacto no risco de liquidez não seja danoso, por exemplo, efetuando o hedge das taxas de juros e definindo políticas e provisões adequadas para as operações de crédito. Outro ponto de atenção está no fato que alguns saldos possuem maturidade conhecida, porém outros podem ser repactuados e outros não possuem maturidade, devendo, assim, haver ferramentas para projetar as saídas e entradas de caixa com estas características.

Para ilustrar de maneira mais tátil os conceitos supracitados, a seção seguinte apresenta o exemplo norte-americano de políticas para controle do risco de liquidez, demonstrando um pouco da aplicação dos conceitos da gestão de liquidez num modelo normativo.

\subsubsection{O Exemplo FED: aspectos da política norte-americana de controle e gestão}

\section{da liquidez, do seu risco e os estudos empíricos relacionados}

Em função das recentes crises, o Federal Reserve (FED) dos Estados Unidos muito tem se preocupado em desenvolver políticas e regulamentações com o intuito de controlar a liquidez disposta no sistema, contribuindo assim para a estabilidade do sistema financeiro e resguardando o mercado de crises vindouras. No entanto, muitas vezes, as políticas não versam diretamente sobre liquidez.

Como exemplo dessa situação pode-se afirmar que o FED mantém uma política de concessão de crédito na qual as contrapartes tomadoras de crédito são obrigadas a manter, apresentar e ou vincular ativos diversos como garantia da quitação de seus débitos. Outra importante característica está na metodologia de monitoramento dessas contrapartes. Essa metodologia, composta de quatro passos, consiste em verificar a solidez das instituições; identificar situações, características e ou relacionamentos que demonstrem que essas instituições assumem riscos maiores do que a sua capacidade lhes permite; verificar se essas instituições realizam a comunicação de todas as informações relevantes; e finalmente produzir indicadores que possam mitigar os eventuais riscos que essas instituições possuam.

As características dessa metodologia demonstram ações um tanto conservadoras que afetam o caixa, pois não permitem saídas desmedidas de caixa, evitando exposições excessivas ao 
risco. Esse posicionamento adotado pelo FED pode ser o balizador de políticas de controle e gestão de fluxos de caixa, no que tange às operações de crédito, influenciando predominantemente as saídas de caixa advindas dessas operações.

Além de estabelecer políticas, o FED incentiva a produção científica que, por sua vez, também versa acerca de elementos relacionados à gestão e controle dos fluxos de caixa. Num dos artigos de discussão do FED, elaborado por Obrien (2007), é abordada a temática dos depósitos compulsórios. São exploradas as características de sua metodologia, como período de apuração, produtos considerados, alíquotas, penalidades para não cumprimento, bem como são comparadas as práticas de diversos países da Organisation for Economic Co-operation and Development (OECD), apontando as semelhanças e diferenças quanto a essa prática. Segundo Obrien (2007), fica claro o papel dos depósitos compulsórios como agente de política monetária, influenciando a liquidez dos sistemas financeiros, e até mesmo sua participação no controle da taxa de juros praticada. Dessa forma, gerir esse ponto deve ser parte integrante de qualquer planejamento referente à gestão e controle dos fluxos de caixa.

Em outro artigo de discussão do FED, Acharya e Naqvi (2010) voltam a abordar a temática da liquidez, afirmando que a possível semente da crise mundial ocorrida entre 2007 e 2009 tenha sido a liquidez abundante no mercado, e que essa situação teria induzido a uma tomada excessiva de riscos, consequente alta de preços, e por fim criado a bolha. Isso teria ocorrido porque, pelo excesso de liquidez, os gestores dos bancos tenderam a sub-precificar os riscos das operações que realizaram, motivados por maximizar seu bem-estar próprio, numa clara manifestação de um conflito de agência.

Outro agravante teria ocorrido devido à percepção dos depositantes, que, no caso de uma crise de preços e do aumento do risco macroeconômico, tenderam a procurar instituições sólidas para remeter seus depósitos, ampliando ainda mais a liquidez do sistema. Para Acharya e Naqvi (2010), a política monetária praticada também tem forte influência na situação, sendo redutora da crise, caso seja contracionista, ou amplificadora, caso seja expansionista. Para os autores, o principal achado é o fato que tomada de riscos das operações bancária, de alguma forma, é função da disposição da liquidez do sistema.

Desse modo, pelos relatos supracitados, quer sejam eles científicos ou regulatórios, percebemse algumas inter-relações entre liquidez, risco e estabilidade do mercado, reforçando ainda 
mais a importância da adequada gestão e controle dos fluxos de caixa para cada instituição e para o sistema em geral. A seção seguinte aborda a gestão tradicional dos fluxos de caixa, numa visão mais conservadora que não considera os riscos de maneira tão explícita, porém que contribui de igual modo para o adequado controle do caixa e de suas movimentações.

\subsection{Gestão tradicional: gestão do caixa}

Além da gestão focada em riscos, um banco também desenvolve o seu processo tradicional de administração, tendo o processo de gestão e controle do caixa como parte integrante. Segundo Hempel e Simonson (1998), gerir a liquidez é um processo muito importante para um banco. Para tanto, os gestores devem observar, controlar e atuar sobre o movimento dos fluxos de caixa quer sejam estes sazonais, cíclicos, de longo e ou curto prazo; manter paralelamente o acesso aos mercados possuidores de recursos por meio de taxas atrativas e boa comunicação com investidores institucionais e agências de rating; prover adequada contingência; avaliar a atratividade dos seus ativos, bem como aprofundar e estabilizar mercados para os seus passivos.

Neste sentido, Hempel e Simonson (1998) desenvolveram um trabalho em que apontam, em teoria, os principais aspectos da gestão de caixa que devem ser observados, sendo esta base de grande importância para enriquecer a discussão deste estudo. Na sequência serão apresentados os principais apontamentos do estudo desses autores. Para efeito de subdivisão explanatória, estes pontos serão divididos em características estruturais, sejam elas exógenas e ou endógenas; e em técnicas gerenciais. Todavia ambas as subdivisões são bastante úteis no desenvolvimento de um arcabouço para este estudo.

Iniciando pelas características chamadas nesta seção de estruturais exógenas, encontram-se, de acordo com Hempel e Simonson (1998), as taxas de juros, quer sejam estas presentes e ou futuras; o efeito do cenário macroeconômico; o impacto do ambiente; e imposição regulatória. A influência da taxa reside no fato de que ativos e passivos bancários normalmente são sensíveis às taxas, quer seja em sua remuneração, quer seja em sua atratividade e competitividade no mercado. De acordo Hempel e Simonson (1998), as taxas de juros influenciam todos os produtos de um banco, sendo o efeito desta dependente do mix e do 
prazo dos produtos, podendo os saldos de ativos e passivos ser afetados dramaticamente por mudanças radicais nas condições de taxas de juros.

Outro ponto observado por Hempel e Simonson (1998) refere-se à taxa de juros futura, representada pela expectativa futura que os investidores têm acerca da taxa de juros, pois, segundo os autores, a indexação das taxas em maior peso, e o prazo em menor peso são relevantes para gestão dos ativos e passivos e, por consequência, do caixa. A preocupação supracitada se dá pelo fato que as projeções e políticas de caixa devem considerar a taxa futura de juros como um elemento de grande influência para o caixa, sendo assim necessária alguma ação no que tange à gestão para garantir a eficácia dos objetivos pretendidos pela instituição, para que estes não fiquem sujeitos às flutuações futuras, por atos de ingerência.

Hempel e Simonson (1998) ressaltam ações de gestão que podem ser úteis para o caso das taxas de juros, dentre eles a utilização de um sistema de simulação que permita avaliar a sensibilidade de ativos e passivos à variação das taxas, bem como a utilização de instrumentos derivativos com o intuito de promover o hedge das posições expostas às taxas de juros.

Ampliando o horizonte das taxas de juros, os gestores dos bancos podem se defrontar com outros dilemas causados por impactos no cenário macroeconômico e no ambiente em que a instituição está inserida. Para Hempel e Simonson (1998), fatores econômicos como recessões, "booms", movimentos bruscos no câmbio, perda da confiança em razão de desgaste na imagem institucional, são considerados eventos e ou variáveis de difícil previsão e gerenciamento e que podem causar necessidades extraordinárias e emergenciais de liquidez.

Deste modo, para desenvolver uma adequada gestão de liquidez, principalmente no que tange ao longo prazo, de acordo com Hempel e Simonson (1998), o gestor deve considerar o ambiente ao redor, tentando antever possíveis movimentos que possam influenciar o caixa e os seus fluxos, inclusive a tendência presente quer seja de uma maior expansão de empréstimos em relação aos depósitos ou vice-versa. Desta forma, na visão dos autores fica claro que os bancos deveriam empregar tempo considerável desenvolvendo passivos potenciais e planos contingenciais para cobrir eventuais necessidades emergenciais causadas por impactos do ambiente e do macro cenário. 
Por fim, na percepção de Hempel e Simonson (1998), a evolução dos órgãos reguladores ocorrida ao longo dos anos permitiu que estes possuíssem adequada capacidade de avaliar se os recursos de uma determinada instituição excedem suas necessidades, e também complementarmente avaliar a capacidade de liquidar ativos, ou acessar fundos federais, entre outros pontos de controle. Esta atuação permite que as políticas dos órgãos reguladores possam impactar significativamente os bancos, com o intuito de trazer higidez ao mercado financeiro, porém em contrapartida causando um impacto importante na gestão e controle de caixa das instituições.

Passando às denominadas características estruturais endógenas, o tamanho pode ser dado como exemplo. Para Hempel e Simonson (1998), o tamanho do banco tem influência na sua liquidez. Exemplificando esta afirmação, um banco, para suprir sua necessidade de liquidez, pode decidir comprar fundos, porém o custo, volume e atratividade desta captação certamente serão diferentes ao menos em parte, de acordo com o seu tamanho. Desta forma, dependendo do tamanho, o banco terá mais acesso a mercados na busca de recursos para suprir suas necessidades, sendo que bancos pequenos normalmente possuem pouco acesso e bancos grandes possuem muito acesso, inclusive internacional.

Outra característica determinante é a tecnologia. Por se tratar de uma instituição financeira, um banco irá requerer muitas informações para gerir adequadamente o caixa, sendo estas informações de natureza diversa e oriundas de diversas fontes, com a volumetria de dados processados correlacionada com o tamanho e com o nicho de atuação da instituição. Em seu trabalho, Hempel e Simonson (1998) afirmam existir diversas soluções de software disponíveis para gerir a liquidez. Ainda assim, segundo os autores, alguns bancos criam seus próprios softwares, provavelmente pela peculiaridade das suas práticas e produtos, bem como pelas diretrizes do modelo de gestão desenvolvido na instituição.

Atendo-se à última característica, o modelo de gestão pode ser considerado per si uma característica estrutural endógena em função de ser influenciado pela alta cúpula e pela cultura da instituição, e também por influenciar os diversos processos de gestão desenvolvidos no banco. Com mais especificidade no que tange à gestão e controle de caixa, Hempel e Simonson (1998) denotam a existência de modelos de gestão para o caixa pautados numa filosofia administrativa que não faz, ou faz pouco uso de aquisição de captações para 
suprir necessidade de liquidez, sendo esta mais conservativa, e uma filosofia mais agressiva que faz uso constante e sistemático de captações para suprir as necessidades de liquidez. Estes modelos são determinantes do perfil de custo, das características dos recursos presentes nos bancos, e das suas ações em períodos com volatilidade anormal.

Partindo para as chamadas variáveis de técnicas gerenciais, Hempel e Simonson (1998) ressaltam diversos aspectos importantes. O primeiro deles é a questão da reserva, que representa o montante mantido em poder do banco para cumprir obrigações de curtíssimo prazo e para atender obrigações exigidas pelos órgãos reguladores e ou políticas econômicas desenvolvidas pelos Estados. Esta reserva é parte integrante do processo de gestão e controle de caixa, sendo necessário otimizar a sua manutenção, para que a reserva, podendo esta também ser denominada como caixa, seja somente a necessária, não impactando na lucratividade e rentabilidade do banco por manutenção excessiva ou insuficiente de reserva.

Segundo Hempel e Simonson (1998), a liquidez bancária não é administrada operação a operação, dado o volume extensivo de operações diárias realizadas em diversas instituições, baseando-se esta, portanto, em saldos sintéticos de passivos e ativos. Sendo assim, os autores consideram as classificações dos elementos uma atividade auxiliar importante para uma adequada gestão. Como exemplo dessas classificações, Hempel e Simonson (1998) sugerem a subdivisão dos ativos em líquidos, ou seja, aqueles que são facilmente conversíveis em caixa, sem incorrer em perdas, e não líquidos, bem como a classificação dos passivos em noncore, ou seja, vulneráveis a retiradas inesperadas e em core para os demais. Diante desta lógica, investimentos de curto prazo estariam disponíveis para cobrir a retirada dos fundos noncore. Essa classificação pode ainda ser mais simplificada, seguindo, por exemplo, o enquadramento dos empréstimos e depósitos em voláteis e ou vulneráveis, sujeitos a sazonalidades, e estáveis.

No entanto, apesar de a última classificação ser mais simplificada e intuitiva, a tarefa de enquadramento não é das mais fáceis. Conforme Hempel e Simonson (1998), é difícil isolar nas flutuações dos elementos o que é sazonal, o que é cíclico, e o que é "tendência". Esta característica acaba dificultando outra importante técnica de gestão de caixa que é a projeção. Para dirimir esta possível distorção, os autores recomendam atenção para o fato de que projeções futuras se baseiam em sazonalidades passadas que podem se alterar com a passagem do tempo. 
Aprofundando-se nos cuidados quanto às projeções, diversos pontos de atenção são evidenciados por Hempel e Simonson (1998) como possíveis atuações na tentativa de promover uma maior qualidade na projeção, e consequentemente na gestão e controle do caixa, bem como da utilização de metodologias estatísticas como ferramental para esta tarefa.

Como exemplos destas ações, os autores citam as tentativas de previsão de eventos, por exemplo, clientes que pretendem adquirir instituições e, por conseguinte, resgatarão seus investimentos; a consideração da sazonalidade dos segmentos, da concentração dos depósitos e empréstimos, dos prazos, e das possibilidades de casamento de necessidades e recursos ao longo do tempo. Não menos importante é a definição da periodicidade e granularidade, sendo que alguns bancos utilizam dados semanais e ou diários em detrimento a dados mensais, e de dezenas de categorias de empréstimos e depósitos.

Quanto aos dados utilizados nas projeções, o balanço pode ser uma fonte de dados históricos utilizado como ponto de partida (HEMPEL; SIMONSON, 1998). Da mesma forma, baseando-se nos achados de Hempel e Simonson (1998), na tentativa de ampliar a acurácia das projeções, o gestor pode ainda procurar correlação entre fluxos de depósitos e taxas de juros, verificando possíveis correlações nestes movimentos, atentar para a necessidade de diversificação da origem dos fundos em alguns momentos, tanto quanto à clientela como ao produto utilizado, e ainda basear-se em movimentos históricos para encontrar picos, analisálos, prever em que condições eles se repetiriam e planejar ações para estes momentos.

Muitos bancos possuem alguma estimativa da sua necessidade de liquidez, no entanto não possuem adequadas políticas e procedimentos para operacionalizar o suprimento e gestão desta necessidade (HEMPEL; SIMONSON, 1998, p. 262). A afirmação supracitada conjugada aos tópicos abordados acima ressaltam, mais uma vez, a importância da gestão e controle do caixa e permitem depreender que diversas medidas devem ser tomadas com intuito de prover adequadas ações e planos para cada situação, inclusive para eventuais contingências. Para Hempel e Simonson (1998), a necessidade contingente de liquidez é causada por eventos não usuais, porém difíceis de serem previstos, sendo os movimentos normalmente não acurados, porém muitas vezes exigidos por força de lei e demandantes de criação de um "colchão" para "amortecer" eventuais impactos inesperados. 
Sendo assim, percebe-se, pela miríade de fatores e variáveis aos quais os gestores serão expostos, que a gestão e controle do caixa, e ou gestão de liquidez, irá requerer muito conhecimento e dinamismo dos gestores, bem como essencial apoio informacional e tecnológico, para que os bancos possam estar providos do adequado ferramental para uma ótima administração de seus caixas, dada ainda a particularidade de cada instituição, seja ela pela filosofia de gestão, pelo tamanho, pelo nicho de atuação ou por qualquer outro fator contextual.

No entanto, apesar dos pontos apresentados fazerem parte de um arcabouço teórico já consolidado, muitos destes necessitam ser validados e testados empiricamente nos dias atuais, permitindo maior compreensão quanto a sua disposição e existência, auxiliando num passo seguinte, ao entendimento de sua importância e função. Outra importante nuance é compreender se os conceitos presentes na literatura internacional se materializam na nação brasileira, ou seja, compreender se as mesmas características também estão presentes no Brasil e se estas se fazem importantes para o banco analisado neste estudo e para pesquisas futuras. 


\section{ESTUdOS ACERCA DA GESTÃO DO CAIXA: AS ABORDAGENS E OS ACHADOS EMPÍRICOS}

A lista de trabalhos acerca da gestão e controle dos fluxos de caixa não é muito extensa, principalmente quando se trata de uma abordagem mais prática, na qual se analise, relate e critique o que de fato está sendo desenvolvido nas instituições; e quiçá quase inexistente quando se trata da gestão do caixa em bancos. Kytönen (2004), em seu trabalho, corrobora a afirmação anterior, ressaltando a pouca quantidade de trabalhos publicados acerca das práticas de gestão e controle do caixa, citando como exemplo os trabalhos de Gitman, Moses e White (1979), Kamath et al. (1985), e Soenen e Aggarwal (1989). Somam-se a estes estudos os trabalhos de Phillips (1997), Soenen (1986), Ozkan e Ozkan (2004), Iturralde, Maseda e SanJose $(2008,2009)$. Dentre estes trabalhos que estudaram a prática da gestão de caixa, nenhum deles teve como objeto de estudo os bancos.

Para compreender melhor a evolução e o direcionamento dos estudos desenvolvidos na temática da gestão e controle do caixa, torna-se necessário evidenciar qual é a abordagem dada ao assunto por alguns destes estudos. Alguns autores utilizaram a ótica econômica para pautar seus estudos, baseando-os nas teorias monetária e da firma para construir modelos que têm o intuito de predizer o montante de caixa que deve ser mantido na instituição dada uma série de variáveis independentes que possivelmente influenciariam essa manutenção. Como exemplos desta abordagem podem ser considerados os estudos de Baumol (1952) com o modelo que trata o caixa como um estoque, e de Miller e Orr (1966) que desenvolveram um modelo estocástico. Os estudos baseados na visão econômica têm como finalidade principal otimizar a manutenção do caixa necessário, contribuindo deste modo para a gestão e controle do caixa.

Nesta mesma linha, de acordo com Kytönen (2004), diversos autores desenvolveram modelos de otimização do caixa, baseados nos modelos de Baumol (1952) e Miller e Orr (1966), agregando outras técnicas e conceitos, como programação linear, modelos de rede e também a teoria financeira, em sua vertente que tenta compreender como as movimentações do caixa criam ou destroem valor. Ainda segundo Kytönen (2004), os modelos baseados na teoria 
econômica, muitas vezes formatados por funções de custo, acabam por não capturar a natureza dinâmica das mudanças nas práticas de gestão e na tecnologia.

Numa linha intermediária de raciocínio, alguns estudos procuraram compreender por que as instituições mantêm caixa e quais variáveis influenciam nesta manutenção. Neste sentido Opler et al. (1999) se dispôs a entender se existiria um nível ótimo de manutenção de ativos com liquidez e, caso afirmativo, por que diversas instituições manteriam um valor tão elevado em caixa. Sobre esta situação, os autores tentaram relacionar a manutenção do caixa com variáveis como crescimento no número de prospectos, desbalanceamento de capital de giro de curto prazo, alavancagem, volatilidade do setor em que as instituições estão inseridas, e tamanho. De acordo com as conclusões do estudo, quanto mais acesso ao mercado de capitais menos caixa será mantido e, quanto mais oportunidades e mais arriscado o ambiente, mais caixa será mantido. De maneira geral, os autores concluíram que, além de possuir a função de redução de custos de transação, a reserva é mantida para aproveitar oportunidades de investimento e aquisições.

Partindo do mesmo embasamento geral, Blanchard, Lopez-De-Silanes e Shleifer (1994) procuraram investigar em seu estudo a preparação dos gestores para lidar com uma entrada inesperada de caixa em função de parecer favorável numa ação judicial, analisando a configuração do conflito de agência sobre a destinação deste fluxo, sugerindo a possível utilização de um prêmio para reduzir este conflito. Blanchard, Lopez-De-Silanes e Shleifer (1994) concluíram que, em geral, sem prêmios o administrador prefere manter o caixa na instituição, à espera de uma oportunidade de investimento lucrativa em detrimento de liquidar uma dívida, distribuir dividendos ou recomprar ações.

Chegando finalmente ao estudo da prática da gestão e controle de caixa, Iturralde, Maseda e San-Jose (2009) são autores de um estudo guiado por esta linha. Este estudo se propôs a analisar as rotinas de gestão de caixa na Espanha. Inicialmente os autores enumeraram as possíveis variáveis que teriam alguma influência na gestão dos fluxos de caixa, como a área e o setor de atuação, o tamanho da instituição, a centralização do processo, a filosofia de gestão, o nível de treinamento, a escolaridade dos gestores, as técnicas, e o período das projeções, de modo a investigar seu relacionamento posteriormente. A pesquisa, que foi operacionalizada pelo envio de 1.500 questionários com taxa de resposta de $14,5 \%$, teve por objetivo verificar a influência das variáveis supracitadas na gestão do caixa e identificar grupos homogêneos de 
instituições que utilizam as mesmas práticas. Por esse estudo também foi possível identificar três grandes funções da área de gestão do caixa, sendo estas a administração do caixa doméstico, o relacionamento com bancos, e a administração de riscos.

Diferenciando as instituições de acordo com turnover, ativos no balanço, número de empregados, setor, nível de treinamento dos gestores; e utilizando para tanto técnicas de análise estatística, os autores concluíram que a filosofia de gestão possui mais influência na determinação do modelo de gestão do caixa se comparada ao tamanho da instituição, ou seja, pela conclusão dos autores a administração do caixa faz parte da cultura administrativa da instituição. Desta forma, o estudo contribuiu para investigar as funções da gestão do caixa, seu inter-relacionamento com variáveis contextuais, e também para verificar possíveis clusters de instituições no que tange a gestão e controle dos fluxos de caixa. Outro importante achado da pesquisa é a constatação da utilização do orçamento como ferramenta de gestão de caixa.

Nesta mesma linha destaca-se o estudo de Iturralde, Maseda e San-Jose (2008), também delineado em instituições espanholas. Para os autores, o aumento de competitividade nos mercados e o surgimento de novos instrumentos financeiros forçaram a utilização da prática de rolling forecasts e de análise de riscos para embasar as ações da gestão de caixa. Os autores ainda ressaltaram a importância da manutenção de ativos com alta liquidez, pelo fato de poderem ser convertidos em caixa por baixo custo, da necessidade de uma gestão próxima e responsável do caixa, em razão da possível falta de caixa potencializar a interrupção do fluxo normal dos negócios.

Phillips (1997) também estudou a temática da gestão do caixa pela ótica da prática, embasando seu estudo principalmente em informações acerca das práticas de gestão de caixa obtidas junto ao órgão denominado Tresuary Management Association. Para Phillips (1997), o único ponto de intersecção entre companhias abertas, companhias fechadas, empresas estatais e empresas sem fins lucrativos é a gestão de liquidez. Pelo estudo de Phillips (1997), para adequada gestão do caixa é fundamental que os gestores e as equipes responsáveis pelo processo possuam: habilidade em projetar os fluxos de caixa, utilizando para isto apropriados métodos; habilidade em aplicar e captar recursos; conhecimento das estratégias, políticas e fontes de recursos; conhecimento dos produtos, qualidade dos serviços e apreçamento; 
conhecimento e habilidade de utilização de tecnologia; conhecimento acerca do mercado de capitais e de crédito, gestão de crédito e de câmbio, modelos de remuneração, legislação e regulação.

Estes conhecimentos e habilidades seriam agrupados e desenvolvidos em ações de gestão como: gestão das aplicações e captações de curto prazo, determinação e controle das posições diárias de caixa, desenvolvimento de estratégias de investimento, relacionamento institucional e administração da informação e tecnologia. Por sua vez, estas habilidades e conhecimentos concretizados nas ações supracitadas conduziriam o processo a ser mais focado no nível estratégico do que no operacional e a um maior envolvimento organizacional, promovendo a participação do processo de gestão e controle dos fluxos de caixa na gestão de riscos, no modelo de remuneração, na definição de metas e na elaboração de orçamento corporativo.

Outros estudos também se dispuseram a investigar as práticas de gestão de caixa em determinado país. Ozkan e Ozkan (2004) analisaram a gestão do caixa pela ótica da decisão do montante mantido em caixa nas instituições do Reino Unido, utilizando uma amostra de 780 instituições britânicas num horizonte compreendido entre 1984 e 1999 por meio da técnica estatística de dados em painel. Em linhas gerais os autores acreditavam que uma das principais explicações de se manter caixa é que este se configura em uma fonte barata de financiamento para a instituição, no entanto, por sua modelagem, tentavam determinar se o montante do caixa mantido na instituição poderia ser explicado por variáveis como tamanho; estrutura societária, sendo esta fracionada ou com poucos sócios; oportunidades de investimento; e influência do principal controlador.

As conclusões do estudo demonstraram relação positiva entre estrutura acionária com poucos sócios e a manutenção de caixa. Neste sentido, as instituições familiares tenderiam a manter mais caixa que companhias abertas. Outra importante evidência do estudo embasado pela teoria da agência reside no fato que os gestores preferem possuir o caixa à disposição para aplicá-lo de acordo com seu desejo, mesmo que isto resulte em decisões que não sejam ótimas, enquanto os acionistas esperam receber este caixa de volta via dividendos. Do mesmo modo os acionistas majoritários tendem a produzir benefícios para si em detrimento dos acionistas minoritários. Ainda pelas conclusões do estudo, do ponto de vista empresarial, esta relação seria moderada pelos bancos, sendo estes, neste contexto, os intermediadores financeiros entre instituições não financeiras, o que possibilitaria minimizar os custos de 
agência, pois esses possuem acesso a informações empresariais confidenciais. Por fim, Ozkan e Ozkan (2004) encontraram correlação positiva entre maior nível de oportunidades de negócios e maior caixa mantido e não encontraram suporte estatístico para o tamanho da instituição e para influência do principal executivo na determinação do montante do caixa mantido.

Outro estudo bastante contributivo em informações sobre a gestão e controle dos fluxos de caixa é o de Soenen (1986). Nele o autor procurou identificar as práticas de gestão de caixa nas instituições do Reino Unido, focando-se na política formulada, na responsabilidade pela gestão, na tecnologia utilizada no processo, e na centralização e ou descentralização do processo de gestão. Para tanto, a intenção foi compreender o processo sistemático de projeção de fluxos de caixa, de taxas de juros e de câmbio, bem como em que extensão esses modelos estão dispostos; como se dá a participação dos bancos neste processo; e de que forma se desenvolvem os possíveis conflitos com outros departamentos relacionados, permitindo deste modo contextualizar a gestão de caixa para a amostra pesquisada.

Pelo estudo de Soenen (1986) podem-se evidenciar pontos bastante interessantes. Para a amostra pesquisada, o controller aparece como um dos principais responsáveis pelo processo de gestão do caixa. Também ficou evidenciada a existência de um comitê para acompanhar o processo, bem como o entendimento predominante de que a gestão do caixa deva ser realizada de forma centralizada. No que tange à projeção propriamente dita, Soenen (1986) concluiu que esta geralmente tem a forma de um orçamento de caixa, com horizonte de 12 meses, algumas vezes acompanhada de um demonstrativo do tipo usos e fontes de recursos. Estas projeções são retificadas por rolling forecasts que variam em grau de detalhamento de frequência, sendo mensal, seguido de trimestral e semanal, os períodos mais comuns.

Quando observado o tamanho da instituição, Soenen (1986) concluiu que em instituições pequenas pouco mais da metade realizam rolling forecasts; não diversificam seu relacionamento com bancos; não se valem de serviços como cash management para otimizar sua gestão; utilizam apenas a consultoria de investimentos, efetivação de transferências de recursos e geração de relatórios. Já as instituições grandes se relacionam e interagem fortemente como muitos bancos, utilizando quase a totalidade dos serviços que estão a sua disposição. 
Soenen (1986) também evidenciou que a maioria das instituições crê que o foco no curto prazo é mais importante. Outro achado foi o fato de que os fluxos de saída de caixa são mais acurados que os fluxos de entrada de caixa. As principais fontes de informação que embasam as projeções são os bancos de dados históricos, as informações financeiras e a intuição, sendo complementadas por uma utilização limitada de indicadores como taxas de juros, câmbio futuro, e outros índices macroeconômicos e comerciais.

Pelos achados de Soenen (1986), os modelos de projeções são simplistas, com um índice de $80 \%$ de não utilização de modelos matemáticos de projeção sendo, portanto, a acurácia, o maior problema das projeções, requerendo desta forma uma maior aplicação de ferramentas quantitativas para auxiliar nas projeções. Quanto aos conflitos internos, Soenen (1986) pôde constatar que, para a amostra analisada, ocorriam conflitos por caixa entre operações de compra e venda, entre produção e pessoal, e também que em algumas instituições as projeções estão subordinadas aos interesses comerciais.

Por fim, é importante evidenciar as contribuições advindas do estudo de Kytönen (2004) acerca da prática de gestão de caixa. De acordo com Kytönen (2004), a evolução do mercado financeiro, as evoluções tecnológicas, o crescimento da competitividade e a internacionalização fizeram com que as atividades de gestão do caixa e tesouraria se tornassem mais importantes nas instituições, gerando mudanças de comportamento nestas atividades. De acordo com Kytönen (2004), estas atividades necessitam de projeções de pagamentos para que se possa investir o caixa excedente de maneira ótima, assim como informações acerca das flutuações de taxas de juros futuras, para que se possam aproveitar movimentos favoráveis.

Outro ponto ressaltado por Kytönen (2004) é o fato de que a gestão do caixa integra as visões de risco e retorno e relaciona liquidez e lucratividade. A esses aspectos somam-se as possíveis razões estratégicas para se manter caixa. Diante da imensidão de aspectos e searas a desbravar, Kytönen (2004) ainda corrobora a afirmação de outros autores de que pouco se sabe acerca das práticas da gestão de caixa, alimentando ainda mais a necessidade de pesquisas acerca da temática. 
Deste modo, pautado na utilidade e aspectos a explorar relatados, Kytönen (2004) avança em seu estudo afirmando que gestão de caixa está dividida entre estratégica e tática e que as principais atividades do processo de gestão do caixa se dividem em planejamento financeiro, orçamento e gestão do capital de giro, responsabilidades estas do tesoureiro e do contador, sendo, o primeiro, o homem dos negócios e, o último, o responsável pelo controle do caixa. A informação que subsidia os processos e decisões, segundo Kytönen (2004), pode ser advinda da posição de caixa e das posições de recursos e aplicações ou de um processo de gestão baseado no rolling forecast, sendo estes processados num sistema "artesanal" ou adquirido.

Complementando os achados dos estudos e indo ao encontro dos objetivos deste estudo, se dá a afirmação presente no trabalho de Kim, Mauer e Sherman (1998), ressaltando bem esta seara ao afirmar que decidir sobre a posição ótima de liquidez de uma instituição é um dos dez problemas ainda não resolvidos em finanças. Esta dúvida se debruça no trade off entre investir em ativos produtivos ou em ativos líquidos, sendo esse trade off permeado por duas linhas de raciocínio, a que se baseia nos motivos contingentes que têm a finalidade de prevenir acontecimentos advindos de impactos futuros, e a que se baseia nos motivos especulativos que visam aproveitar oportunidades futuras de investimento. Complementando a afirmação de Kim, Mauer e Sherman (1998), de acordo com Damodaran (1997), há significativas diferenças de liquidez entre os vários setores, sendo o setor bancário um dos setores que possui grande especificidade.

Desta forma, fica evidenciada a importância da pesquisa acerca das práticas de gestão e controle dos fluxos de caixa para a otimização do resultado global da instituição também pela ótica empírica, principalmente quando esta instituição for um banco. Também é possível inferir, pelas constatações tanto teóricas quanto empíricas, que a pesquisa que envolva gestão e controle do caixa e dos seus fluxos e bancos é de modo geral incipiente e talvez quase inexistente quando a estas duas delimitações se adiciona a participação da contabilidade. Ainda assim em alguns dos estudos supracitados pôde-se observar a citação literal da participação da contabilidade no processo de gestão de caixa das instituições. O próximo capítulo tratará da possível contribuição da contabilidade para este estudo. 


\section{A PARTICIPAÇÃO DA CONTABILIDADE NA GESTÃO DOS BANCOS E DOS FLUXOS DE CAIXA}

\subsection{Contabilidade: sua essência gerencial e sua contribuição à gestão bancária}

Segundo Iudícibus, Martins e Carvalho (2005), a contabilidade nasceu gerencial, ou seja, voltada para atender às necessidades dos usuários internos, gestores, se desdobrando posteriormente para atender usuários externos, proprietários, quando o último se desvincula do primeiro. No entanto, a contabilidade, no seu veio gerencial, continuou se desenvolvendo e evoluindo, constituindo, na prática, uma das atividades sob responsabilidade da área denominada controladoria (BORINELLI, 2006).

Para Frezatti et al. (2009), a controladoria é o órgão da instituição cuja missão consiste em zelar pela eficácia do seu processo de gestão, cuidando, portanto, para que os usuários disponham de todas as informações necessárias para atingir plenamente seus objetivos. Ainda segundo Frezatti et al. (2009), a controladoria tem como função disseminar conhecimento, modelar e implementar sistemas de informação valendo-se das contabilidades gerencial e financeira. Sendo assim, ao nos atentarmos aos conceitos básicos, de missão e funções da controladoria supracitadas, percebe-se a utilidade da contabilidade em seu veio gerencial para a gestão dos negócios, independente de seu ramo de atuação.

Desse modo, a contabilidade também possui papel importante na gestão e controle dos bancos, instituições essas que necessitam de informações tempestivas e controles eficazes que possibilitem a elas operarem satisfatoriamente em ambientes altamente voláteis, competitivos, e regulados, e que dessa forma necessitam não só da informação como também do direcionamento provido pelos conceitos e abordagens teóricas emanados da contabilidade. Um exemplo da participação da contabilidade na gestão bancária está presente no trabalho da Fundação Instituto de Pesquisas Contábeis Atuariais e Financeiras - FIPECAFI (2005), realizado por solicitação da Federação Brasileira dos Bancos (FEBRABAN), que pretendeu estudar a apuração do spread da indústria bancária. 
Este estudo destacou-se, pois, além de conter muitas análises macro e microeconômicas de excelente qualidade acerca da temática, é pioneiro por relacionar o spread diretamente às demonstrações contábeis. Isso vai ao encontro da sustentação deste trabalho, pois há alguns estudos acerca dos fluxos de caixa realizados com enfoque de riscos e econômico, porém nenhum relacionou diretamente essa temática às informações contábeis.

O trabalho da FIPECAFI (2005) pretendeu demonstrar o spread dos principais bancos brasileiros, relacionando os spreads bruto, direto e líquido, nas aberturas de Pessoa Física (PF) e Pessoa Jurídica (PJ) mostrando que o último é bem menor que o primeiro. Adicionalmente o estudo procurou criar um modelo de Demonstração do Valor Adicionado (DVA), para demonstrar como é distribuído o valor criado entre as diversas partes interessadas na sociedade. Ficou evidente nessa montagem que as receitas e despesas financeiras são os principais itens geradores de valor em um banco. Por esse trabalho também se tornou perceptível a utilidade da informação contábil e seu eventual norteamento para o setor financeiro.

\subsection{Artefatos, técnicas e modelos contábeis: seu auxílio e participação na gestão e controle dos fluxos de caixa}

O setor bancário brasileiro é considerado um dos mais evoluídos na economia do país, em parte devido à utilização maciça de recursos tecnológicos, o que permite a essas instituições a melhoria dos processos e dos serviços prestados e as torna cada vez mais eficientes (BRITO et al., 2005). Sendo assim é importante ressaltar que é frequente, em bancos, a busca de artefatos gerenciais que possam aprimorar, facilitar e ou suportar os processos de tomada de decisão. O achado do estudo de Verbeeten (2006) vai ao encontro destas afirmações, quando conclui que instituições financeiras utilizam técnicas sofisticadas de orçamento de capital para lidar com incertezas do ambiente onde atuam. A construção e desenvolvimento desses artefatos mais uma vez permeia a contabilidade, no seu veio gerencial, demonstrando que esta é muitíssimo importante para a gestão bancária.

Assim como se observa a utilidade da contabilidade no processo de gestão dos bancos como um todo, com desenvolvimento e utilização de técnicas e ferramentas de controle gerencial, também é possível encontrar sua presença na gestão e controle dos fluxos de caixa. $\mathrm{Na}$ análise 
dos estudos acerca da gestão e controle dos fluxos de caixa, a participação e ou a oportunidade de atuação da controladoria neste processo é evidente. Exemplificando esta afirmação, em seu estudo, Iturralde, Maseda e San-Jose (2009) citam a utilização de dados contábeis de ativos na gestão do caixa, bem como a utilização do orçamento, sendo esta uma ferramenta importante para esse processo de gestão. Phillips (1997) cita a relação entre a habilidade de projeção de fluxos de caixa e a atividade de definição de modelos de projeção que, segundo seu estudo, estão sob a responsabilidade da controladoria.

Nesse mesmo sentido, pode-se citar o trabalho de Dent (1996) que, ao tratar da globalização dos métodos de contabilidade gerencial, dando como exemplo as instituições japonesas que definiram estratégias globais, padronizaram seus produtos, conquistaram ganhos mundiais de escala e ganharam mercado das instituições ocidentais, sugere a formulação de um sistema de informação contábil global e defende, também de forma mais consolidada, a utilização de informação de fluxos de caixa gerados pela contabilidade gerencial para subsidiar a gestão, sendo esta uma possível fonte de vantagem competitiva utilizada pelas instituições que foram objeto do estudo para entrar em novos mercados.

Já o estudo realizado por Soenen (1986) afirma que as projeções integrantes do processo de gestão e controle dos fluxos de caixa normalmente tem a forma de um orçamento de caixa, complementado ou não por um demonstrativo de usos e fontes de recursos e atualizado pelos chamados rolling forecasts, que são atualizações periódicas do orçamento, ressaltando também a importância da existência de fontes de informação fidedignas para o desenvolvimento destes processos. Kytönen (2004), que buscou em seu estudo investigar o mundo da prática da gestão do caixa, também comenta em seu estudo da participação do orçamento de caixa e do contador no processo.

Pela sequência de citações nos estudos mencionados, o orçamento pode, de alguma forma, ser parte integrante da gestão do caixa, inclusive nos bancos. Especificamente no caso dos bancos, o caixa é resultante das operações realizadas no âmbito das políticas de investimentos, de prazos de recebimentos e pagamentos, de captação e aplicação de recursos; sendo esta série de operações financeiras realizadas ao longo de um período responsável pela formação dos saldos dos ativos e passivos, das contas de resultado, do gap em cada um dos prazos e, por conseguinte, dos fluxos de caixa propriamente ditos. 
Partindo destas considerações, as diversas áreas poderiam elaborar orçamentos dos resultados e saldos de ativos e passivos esperados para os diversos produtos em determinado período futuro. Com base nessas projeções, seria elaborado um orçamento de caixa, projetando os fluxos de caixa do período e o saldo de caixa final pela diferença entre saldos de caixa em momentos distintos, descontando-se apropriações efetuadas pelo regime de competência que ainda não transitaram pelo caixa, sendo, nesse caso, o orçamento de caixa elaborado de forma indireta.

Alternativamente, caso houvesse disponibilidade de informações, as áreas de negócios da instituição poderiam elaborar seus respectivos orçamentos projetando os próprios fluxos de caixa esperados para cada item financeiro (ativo ou passivo) ou grupo de produtos; por exemplo, projetariam expectativas quanto à amortização de empréstimos concedidos, descontos para antecipação, recebimentos de juros, e novas concessões de empréstimos; sendo, nesse caso, o orçamento do caixa para o período em questão realizado de forma direta pela consolidação das projeções orçamentárias das variáveis supracitadas.

Em ambos os casos, a projeção de caixa é resultado de projeções de saldos e resultados ou de concessões, recebimentos e pagamentos realizadas pelas áreas de negócios e áreas corporativas; ou seja, há uma interação entre a função da projeção de caixa e o processo orçamentário. O método indireto de fluxo caixa para seu cálculo efetivo demanda saldos projetados de ativos e passivos, bem como receitas e despesas referentes a esses ativos e passivos; já o método direto de fluxo de caixa, por sua vez, requer projeção das entradas e saídas de caixa.

Examinadas as características a fundo, entre diversas ferramentas gerenciais disponíveis, o orçamento se coloca possivelmente em posição de destaque. Por meio desse artefato, gestores de instituições financeiras podem ter melhores subsídios para previsão e acompanhamento dos fluxos de caixa e para direcionamento das ações relacionadas à gestão dos ativos e passivos, do gap e consequentemente da liquidez como um todo, pois esta ferramenta pode aliar objetivos estratégicos quantificados em saldos remanescentes e em saldos vindouros de ativos e passivos, bem como em receitas e despesas resultantes das diversas indexações, sendo possivelmente uma fonte muito útil para a gestão de liquidez. Estas afirmações 
corroboram para uma possível participação e ou oportunidade de participação da contabilidade na gestão de liquidez.

Abrindo um parêntese nesta análise, tem-se que o orçamento, artefato da contabilidade, mais especificamente do controle gerencial, é a materialização do planejamento e do controle de resultados (WELSCH, 1983). Ele auxilia na codificação de objetivos da instituição em números, sendo base para criação de indicadores e controles e auxiliando no alcance dos objetivos pré-estabelecidos. Dessa forma, o orçamento é parte integrante do planejamento tático, conforme divisão do planejamento empresarial proposta por Ansoff, Declerck e Hayes (1976).

A importância do orçamento também é evidenciada por Horngren, Sundem e Stratton (2004), quando ressaltam a sua participação na função de compelir os gestores a pensar no futuro da organização, por meio do auxílio ao planejamento de ações, à projeção de expectativas e à coordenação dos esforços de subunidades para que satisfaçam os objetivos gerais da organização. Essas características são também ressaltadas por Garrison e Noreen (2001), pois tratam o orçamento como um plano detalhado da aquisição e do uso de recursos, financeiros ou de outra natureza, durante um período especificado, sendo esse a representação de um plano futuro, expresso em termos quantitativos.

Planejamento e controle efetivos são essenciais para o alcance das metas e objetivos de uma empresa (FREZATTI, 2009). Para isso, o orçamento pode ser útil, como parte integrante do sistema de gestão da empresa (VAN DER STEDE, 2001), tendo como propósitos planejar, coordenar e organizar atividades, alocar recursos e até mesmo motivar funcionários (COVALESKI et al., 2006). A existência destes elementos ressalta a necessidade de informação tempestiva e de qualidade para otimizar a utilização do caixa mínimo e reduzir o custo da liquidez, como também elucida a oportunidade de participação da contabilidade na gestão do caixa.

Adicionalmente essa forma de utilizar orçamentos das áreas é extremamente vantajosa, pois permite o entrelaçamento das previsões de saldos, resultados e fluxos de caixa, criando assim uma visão nestas três dimensões. Deste modo, advindo do processo orçamentário, emerge a figura do orçamento de caixa, um instrumento de controle gerencial que possivelmente faça 
parte do arcabouço de artefatos de controle gerencial utilizados em bancos para o acompanhamento e a gestão contínua do caixa.

Assim como o orçamento geral com foco no resultado, esta ferramenta possibilitaria a avaliação e a previsão do caixa gerado e consumido nos meses subsequentes, subsidiando ações que conduzam à otimização da alocação dos recursos. No entanto, a principal limitação deste relacionamento reside nos fatos da suposta estagnação das projeções orçamentárias, bem como nas reservas orçamentárias contidas nas referidas projeções. Estas limitações podem ser minimizadas pela realização do processo de rolling forecast, que consiste na atualização das projeções orçamentárias com as melhores estimativas possíveis para períodos mais curtos que os costumeiramente praticados nos processos orçamentários das instituições.

Outro importante conceito advindo do controle gerencial e que se relaciona com a gestão do caixa é o Modelo de Gestão Econômica (GECON), modelo que, segundo Catelli, Parisi e Santos (2003), se caracteriza por uma visão holística da empresa associada ao enfoque na gestão dos negócios e na mensuração e conceituação econômica. Explicitamente, para Catelli, Parisi e Santos (2003), a visão holística se caracteriza por um conjunto de áreas de responsabilidades, que apuram seus resultados econômicos e não somente seus custos, cujos gestores tomam decisões visando maximizar o resultado global de organização. Já a mensuração segundo os conceitos econômicos busca trazer relevância para a informação contábil tornando-a mais próxima da realidade econômica de cada evento, proporcionando a geração de informações úteis para a tomada de decisão.

Em linhas gerais, segundo Catelli (1999), os princípios do GECON defendem a eficácia da empresa por meio da eficácia das áreas, sendo essas geridas em função de sua responsabilidade, e seus gestores possuindo comportamento de donos do negócio, estando todas as ações atreladas à missão, visão e planejamento da organização. Ainda segundo Catelli (1999), esse modelo permite maior transparência, envolvimento dos gestores, descentralização do processo decisório, eficácia no processo de gestão e consequente minimização dos riscos.

Relacionando os conceitos contidos no GECON à temática deste estudo, percebe-se intersecção de conceitos, bem como oportunidades de contribuição, pois a correta gestão do caixa nos bancos permitirá uma maior eficácia do resultado global da organização, assim 
como a adequada gestão dos recursos em cada área de negócios é necessária para que o caixa seja adequadamente administrado e excessos ou necessidades de caixa não planejados possam ser evitados. Outro ponto relevante trata-se da qualidade da informação, pois uma informação contábil revestida de significado econômico poderá ser de estrema importância e utilidade para projeções e consequentemente para a gestão do caixa da empresa.

Frente a estas evidências, percebe-se que a controladoria é fundamental no processo de gestão e controle do caixa, quer seja na organização dos dados contábeis, gerenciais e financeiros, produzindo e disponibilizando informações úteis para subsidiar a tomada de decisões, bem como auxiliando na definição dos modelos e na disponibilização de ferramental útil para os gestores. Desse modo, fica evidente que, para a adequada gestão e controle de seus fluxos de caixa, os bancos necessitam de informações tempestivas e com qualidade. Sendo assim, podese inferir que existe uma tangente entre a gestão de riscos e a contabilidade, possuindo a última, potencial utilidade para a gestão e controle dos riscos de liquidez, especificamente na preparação e disponibilização de informações acerca dos prazos, taxas, projeções em forma de cenários, preparação de dados históricos para embasar modelos, auxílio na definição de modelos e ferramental, entre outras atividades.

Deste modo, a contabilidade pode contribuir tanto na disponibilização de informações financeiras e não financeiras que subsidiem as decisões, como na construção e implantação de ferramentas que permitam aos gestores prever com maior grau de assertividade os movimentos dos recursos, participando do processo de gestão de riscos de liquidez, bem como que permitam verificar eventuais desvios entre o planejado e o realizado, possibilitando desenvolvimento de análises relevantes que possam gerar ações congruentes aos objetivos da instituição.

Finalmente percebe-se, quer seja pelos conceitos emanados, quer seja pelos estudos embrionários, que a contabilidade dentro do arcabouço de suas abordagens teóricas e dos seus estudos empíricos pode contribuir para o entendimento e aprimoramento da gestão dos fluxos de caixa dos bancos, permitindo a compreensão, o enriquecimento da informação disponível para a tomada de decisão, a estruturação dos processos de gestão e consequentemente o alcance dos objetivos organizacionais com eficácia. 
Dadas essas condições, no decorrer das seções e subseções conseguintes, os conceitos e práticas contábeis, na sua vertente de controle gerencial, bem como suas abordagens teóricas permearão o desenvolvimento das considerações e formulações com o intuito de compreender como se relacionam as variáveis envolvidas na gestão e controle dos fluxos de caixa no banco que será objeto deste estudo de caso, para que, numa evolução futura, com aprofundamentos deste estudo e com outras pesquisas correlacionadas, seja possível recomendar medidas que permitam tornar o processo de gestão e controle dos fluxos de caixa de uma instituição ótimo dado o contexto em que estiver inserida. 


\section{A ABORDAGEM DO CICLO DE VIDA ORGANIZACIONAL}

A abordagem do ciclo de vida organizacional emana de outras duas abordagens conceituais comumente utilizadas para estudos em contabilidade: a contingencial e a configuracional. Não obstante à frequente utilização da abordagem contingencial na tentativa de explicar problemas em contabilidade gerencial (SOUZA; NECYK; FREZATTI, 2007), ela tem sido criticada em razão de sua aplicação em diferentes estudos resultar em conclusões dissonantes e não generalizáveis.

Os fatos que mais incomodam os críticos da abordagem contingencial são a especificidade dos fatores contingenciais para cada estudo e o fraco relacionamento estabelecido entre estes fatores e o desempenho da organização (CHAPMAN, 1997; CHENHALL, 2003; DRAZIN; VAN DE VEN, 1985; FISHER, 1995; OTLEY, 1980; SELTO; RENNER; YOUNG, 1995). A abordagem configuracional, por outro lado, reúne um conjunto de fatores contingenciais interdependentes entre si, de modo que a mudança de um dos fatores implicaria em um transtorno no sistema, caso os demais fatores não acompanhassem a mudança.

Segundo Meyer, Tsui e Hinings (1993), apesar de a abordagem contingencial muito ter contribuído para a pesquisa em contabilidade gerencial, a abordagem configuracional pode ser mais útil e profunda, pois poderia prover uma visão mais holística das questões de pesquisa, bem como um agregado coeso de fatores contingenciais que interagiriam sobre determinado contexto. Desse modo, essa abordagem poderia auxiliar no entendimento de como o arranjo entre os fatores contextuais pode afetar os fenômenos organizacionais.

Calcada então em elementos contingenciais e configuracionais, nasce a abordagem do ciclo de vida organizacional, que procura explicar como as organizações se desenvolvem com o passar dos anos e qual configuração de fatores e características está presente em cada fase da vida das organizações influenciando sua gestão, seu desempenho e, consequentemente, sua contabilidade gerencial, buscando de certo modo analogia no ciclo de vida biológico.

Segundo Souza et al. (2007), os modelos-fonte da abordagem do ciclo de vida organizacional são os de Greiner (1972), Christensen e Scott (1964), Rhenman e Adler (1973), e Lippitt e 
Schmidt (1967). Estes modelos possuíam idade e tamanho como variáveis determinantes. Os trabalhos supracitados motivaram diversos outros, como os de Quinn e Cameron (1983), Miller e Friesen (1980, 1983, 1984), e Miller (1986, 1987), destacando-se, na seara da pesquisa, segundo a abordagem do ciclo de vida organizacional, os nomes de Miller e Friesen. Conforme estudo bibliométrico de Carvalho et al. (2010), os trabalhos de Miller e Friesen (1983, 1984) são os mais citados pelos demais, demonstrando, portanto, a relevância destes autores para a temática.

Para Souza et al. (2007), o modelo desenvolvido por Miller e Friesen (1984) destaca-se pela profundidade conceitual e pelos testes empíricos realizados. O modelo de Miller e Friesen (1984) considera cinco estágios para o ciclo de vida das instituições, sendo eles nascimento, crescimento, maturidade, rejuvenescimento e declínio. Este modelo, de forte influência configuracional, vai além da idade e do tamanho, elencando outros elementos determinantes, entre eles, estrutura, estratégia, inovação, informação, controle e ambiente, classificando-os como características centrais de cada estágio. Além destas, os autores ainda consideram características como nível de formalização, nível de centralização e de burocratização e nível de sofisticação como condicionantes das características centrais. Desta forma, o modelo contém uma configuração para cada estágio, o que possibilita o enquadramento das organizações.

Sucedendo os trabalhos de Miller e Friesen (1983, 1984), outros foram desenvolvidos com a mesma abordagem, também demonstrando que esta poderia ser útil para trabalhar problemas da contabilidade gerencial. Moores e Yuen (2001) utilizaram o modelo de Miller e Friesen (1984) para verificar se os sistemas de controle gerencial diferem durante os estágios do ciclo de vida; utilizando-se da técnica estatística de análise de cluster, concluíram que a abordagem do ciclo de vida é útil para explicar as mudanças nos sistemas de controle gerencial.

Frezatti et al. (2009) especificamente constataram que o processo de planejamento difere de acordo com o ciclo de vida. Alguns outros autores utilizaram essa abordagem para explicar as variações dos sistemas de controle gerencial, por exemplo, Auzair e Langfield-Smith (2005), Davila (2005), Granlund e Taipaleenmäki (2005), Souza et al. (2007), Silvola (2008a, b) e Kallunki e Silvola (2008). Porém a tônica do trabalho de Moores e Yuen (2001) não é a observada em todos os estudos. Em geral os estudos que utilizaram a abordagem do ciclo de vida organizacional não têm procurado discutir, reforçar ou dar robustez aos modelos 
existentes, mas sim criar novos modelos; dessa forma, ficam dificultadas conclusões congruentes entre os diversos modelos.

Dentre outros modelos derivados de Miller e Friesen (1984), vale destacar também o de Lester, Parnell e Carraher (1993) que, assim como o modelo que o inspira, é composto por cinco estágios: existência, sobrevivência, sucesso, renovação e declínio. Esse modelo leva em consideração características como estratégia, estrutura, estilo de gestão, situação organizacional, grau de segmentação de mercado, pioneirismo, benchmarking, amplitude das linhas de produtos ou serviços, singularidade, eficiência e satisfação com o desempenho. $\mathrm{O}$ quadro abaixo sintetiza as principais características de cada um dos estágios supracitados, com base nos estudos de Lester, Parnnell e Carraher (1993), Silvola (2008) e Frezatti et al. (2009).

Quadro 1 - Estágios do ciclo de vida organizacional e suas características

\begin{tabular}{|c|c|}
\hline Ciclo & Características Predominantes \\
\hline Existência & $\begin{array}{l}\text { Marca o início do desenvolvimento organizacional, caracterizado pelo foco na viabilização dos negócios; } \\
\text { pela identificação de clientes potenciais, ou seja, prospecção um número suficiente de clientes que } \\
\text { suporte a existência da organização; pelas decisões e pelo controle concentrados nas mãos de poucas ou } \\
\text { até mesmo uma pessoa; e pela tendência organizacional de criar seus próprios ambientes. Possivelmente } \\
\text { possua menos de } 10 \text { anos de fundação }\end{array}$ \\
\hline Sobrevivência & $\begin{array}{l}\text { Caracterizado pela busca pelo crescimento; pelo desenvolvimento formal de uma estrutura; pelo } \\
\text { estabelecimento de competências distintivas; pela definição de metas objetivando garantir continuidade e } \\
\text { competitividade; e pela análise do ambiente. }\end{array}$ \\
\hline Sucesso & $\begin{array}{l}\text { Caracterizado pela formalização burocrática e controle, com predominância de políticas e procedimentos, } \\
\text { além de subordinação e hierarquia altamente formais; pelo ambiente analisável; e pela gestão com foco no } \\
\text { planejamento estratégico. Predomina também a tendência a proteger a riqueza gerada em detrimento de } \\
\text { buscar novos mercados. }\end{array}$ \\
\hline Renovação & $\begin{array}{l}\text { Caracterizado pela busca da colaboração e trabalho em equipe; pela inovação e criatividade; pela } \\
\text { utilização de estruturas matriciais; pelas decisões descentralizadas; pela valorização das necessidades dos } \\
\text { clientes, sendo essas colocadas à frente das dos sócios. Mesmo sendo organizações burocráticas, seus } \\
\text { membros são encorajados a trabalhar sem elas. Ainda destacam-se a diversificação das linhas de produtos } \\
\text { e utilização de sistemas sofisticados de planejamento e controle. }\end{array}$ \\
\hline Declínio & $\begin{array}{l}\text { Caracterizado pelo foco na política e no poder, pela preocupação dos administradores com as metas } \\
\text { pessoais em detrimento às da organização,bem como pelos prejuízos e perda de mercado em função da } \\
\text { incompreensão da demanda nos estágios anteriores. O controle torna a ser centralizado, os conflitos de } \\
\text { influência são presentes e inovação em produtos é pequena }\end{array}$ \\
\hline
\end{tabular}

Conforme abordado anteriormente, e ressaltado inclusive pelos estudos acerca da gestão do caixa (ITURRALDE; MASEDA; SAN-JOSE, 2009; OZKAN; OZKAN, 2004), 
provavelmente os fatores contextuais como, por exemplo, tamanho, idade, filosofia de gestão, entre outros fatores, influenciem, de alguma maneira, a gestão e controle dos fluxos de caixa das instituições. Associando-se esta percepção aos conceitos supracitados, pode-se inferir que a abordagem do ciclo de vida organizacional pode de alguma forma contribuir para explicar como estão dispostas e inter-relacionadas estas características e como variam de acordo com o estágio da instituição no ciclo de vida organizacional.

Finalizando desta maneira a circunscrição desta temática corroborada por estudos anteriores que correlacionaram práticas gerenciais com estágio no ciclo de vida organizacional (FREZATTI, et al., 2009; LESTER; PARNELL; CARRAHER, 1993; MOORES; YUEN, 2001; SOUZA et al., 2007), inclusive especialmente o estudo de Frezatti et al. (2009) sobre correlação de ciclo de vida com o planejamento estratégico, e mais especificamente com o orçamento, cogita-se essa relação também em bancos, e especificamente no banco em análise neste estudo, em relação ao processo de gestão e controle dos fluxos de caixa, que possui também alguma ligação com o orçamento e contabilidade gerencial, conforme citado na seção anterior. 


\section{O INTER-RELACIONAMENTO DAS TEMÁTICAS TEÓRICAS E A FORMAÇÃO DO CONSTRUTO NORTEADOR}

\subsection{A interação das temáticas}

Frente ao arcabouço teórico previamente apresentado que partiu da contextualização da atividade das instituições financeiras, passando pela gestão bancária da liquidez tanto tradicional como focada em riscos, também pelos estudos acerca da gestão de caixa e seus fluxos, pelo papel contributivo da contabilidade nesta temática e finalmente pela abordagem do ciclo de vida organizacional, pretende-se, nesta seção, consolidar as intersecções entre as temáticas de modo a estabelecer as ideias que permearão o estudo empírico, estando estas implícitas nos instrumentos de coleta de dados, e consequentemente na análise dos dados e considerações acerca dos achados deste estudo.

Nas próximas subseções serão identificados os possíveis elementos que possam caracterizar o processo de controle e gestão dos fluxos de caixa em um banco, de modo a possibilitar a associação destas características ao seu estágio no ciclo de vida organizacional, sendo esta abordagem do controle gerencial aquela escolhida na tentativa de analisar o fenômeno em estudo.

\subsection{Modelo de gestão: envolvidos, perfil e enfoque}

O controle de caixa é fundamental para subsidiar a gestão, pois quanto melhor a estimativa dos fluxos de caixas, menor será o erro da projeção agregada, menor será o caixa estagnado, maior será a quantidade de recursos aplicados em opções rentáveis de produtos, e maior será a rentabilidade geral do banco. Nesse sentido, conforme afirmam Rogers, Rogers e Ribeiro (2005), todas as áreas impactam de alguma forma o caixa pelas suas decisões, e deste modo todas elas deveriam se envolver no processo de gestão de caixa.

Entretanto, duas áreas se destacam com maior ênfase na gestão do caixa: tesouraria e controladoria (KYTÖNEN, 2004). A tesouraria normalmente atua como caixa central 
(SANTOS, 2005), sendo esta a intermediadora interna dos fluxos de caixa na instituição. Segundo Hoji (2000), todas as áreas da instituição possuem direta ou indiretamente algum vínculo com a tesouraria, uma vez que aproximadamente a totalidade das operações realizadas, em algum momento, se tornará um fluxo de entrada ou de saída de caixa. De maneira geral, a tesouraria centraliza a administração do caixa, bem como participa do diálogo e discussão sobre a alocação destes recursos.

Já a controladoria, que possui como principal missão zelar pela otimização da riqueza e congruência de objetivos, deve participar de grande parte das decisões, sendo que, especificamente quanto à gestão do caixa, tem a função de disponibilizar informações úteis e tempestivas para subsidiar o processo de gestão, auxiliar as áreas na definição de seus modelos de projeção e controle dos fluxos de caixa, induzir os gestores a tomar decisões assertivas, auxiliar nas pesquisas empíricas, e quiçá na formulação de teorias que possam auxiliar a entender e até mesmo prever comportamentos e tendências do processo de gestão e controle dos fluxos de caixa.

Neste sentido, tanto a controladoria como a tesouraria estarão dispostas num ambiente em que haverá maior ou menor participação de cada uma destas áreas. Do mesmo modo, as demais áreas comerciais do banco também deveriam ser participantes ativas, sendo esta participação muitas vezes inexistente devido à centralização do processo de gestão e controle dos fluxos de caixa. Fica deste modo implícito que o envolvimento possa ser uma característica que possua influência na forma como os fluxos de caixa são geridos nos bancos e que, de alguma forma, este modelo sofreria alguma interferência do ciclo de vida organizacional, sendo esta afirmação um dos objetos das análises deste estudo. O estudo de Soenen (1986) corrobora as afirmações supracitadas, pois relata a centralização e ou descentralização do processo de gestão do caixa, bem como a existência de conflitos interdepartamentais pela gestão do caixa, sendo ambas as observações consideradas exemplos da característica envolvimento.

Outra característica bastante abordada em vários estudos é o enfoque da gestão. Por exemplo, Kytönen (2004), Phillips (1997) e Frezatti (1997) relatam, em seus estudos, a existência dos enfoques de gestão do caixa, podendo este ser tático ou estratégico. Um enfoque mais tático possui uma função mais restrita, com a finalidade de viabilizar outras diretrizes mais amplas e complexas; enquanto um enfoque mais estratégico afeta principalmente as decisões de longo prazo e de cunho realmente estratégico, conforme afirmação de Frezatti (1997). 
O enfoque de que tratam esses estudos está intrinsecamente relacionado às decisões que serão tomadas. Dentre as decisões sobre as quais as áreas envolvidas terão que versar e tecer conclusões, estão compreendidas: o incentivo à captação ou à aplicação conforme necessidade, as mudanças de nicho de atuação, as decisões de investimentos em geral, as campanhas comerciais para incentivar determinado produto, o acompanhamento dos vencimentos das carteiras existentes e do índice de concentração dos clientes, o acompanhamento da participação no mercado e da concorrência, as projeções de curto e de longo prazos dos fluxos de caixa, e o acompanhamento das projeções em comparação ao ocorrido.

Desta posição dicotômica, é possível depreender também posições intermediárias em termos de enfoque, com a coexistência dos enfoques tático e estratégico, porém com predominância de um deles. A condução do processo decisório de gestão do caixa, a influência da alta administração, e a relevância das decisões advindas deste processo na vida da organização poderão indicar o enfoque adotado, que será diferente de instituição para instituição. Finalmente a existência de diferentes enfoques possivelmente também esteja relacionada com estágios do ciclo de vida organizacional, o que também será analisado na sequência deste trabalho, para o banco analisado.

Por fim, dentre os componentes participantes e ou influentes do processo de controle dos fluxos de caixa, também está o perfil do gestor conforme definido por Frezatti (1997). De acordo com o autor (1997), este gestor pode ser mais acomodado e se eximir da responsabilidade do impacto das suas decisões na gestão do caixa, considerando o caixa como função de outras variáveis nas quais ele não possui interferência; ou ser mais pró-ativo, acompanhando de maneira próxima os fluxos de caixa advindos das suas decisões, procurando otimizar estes fluxos e pensando de maneira sistêmica sobre a consequência de suas decisões para o caixa da instituição. Do mesmo modo que no enfoque, é possível encontrar posições intermediárias de perfil entre os extremos apresentados, e se espera encontrar relação entre o perfil de gestor e o estágio no ciclo de vida organizacional no desenvolvimento deste estudo. 
Sendo assim, características como o envolvimento das áreas, devido à centralização ou descentralização do processo gestão; o enfoque da gestão, sendo esse mais tático ou estratégico; bem como o perfil dos gestores, sendo este de acomodação ou de pró-atividade, compõem uma macro característica, denominada neste estudo de modelo de gestão da instituição que, de alguma forma, influenciará o direcionamento e as decisões do processo de gestão e controle dos fluxos de caixa. Corroborando com a construção acima descrita, Iturralde, Maseda e San-Jose (2009) citam a filosofia de gestão como uma das variáveis que influenciam a gestão dos fluxos de caixa, sendo esta possivelmente, no contexto em que está inserida, um sinônimo para o modelo gestão. A figura abaixo tenta sintetizar a influência idealizada do modelo de gestão no processo de gestão e controle dos fluxos de caixa, com cada uma das suas características-chave componentes.

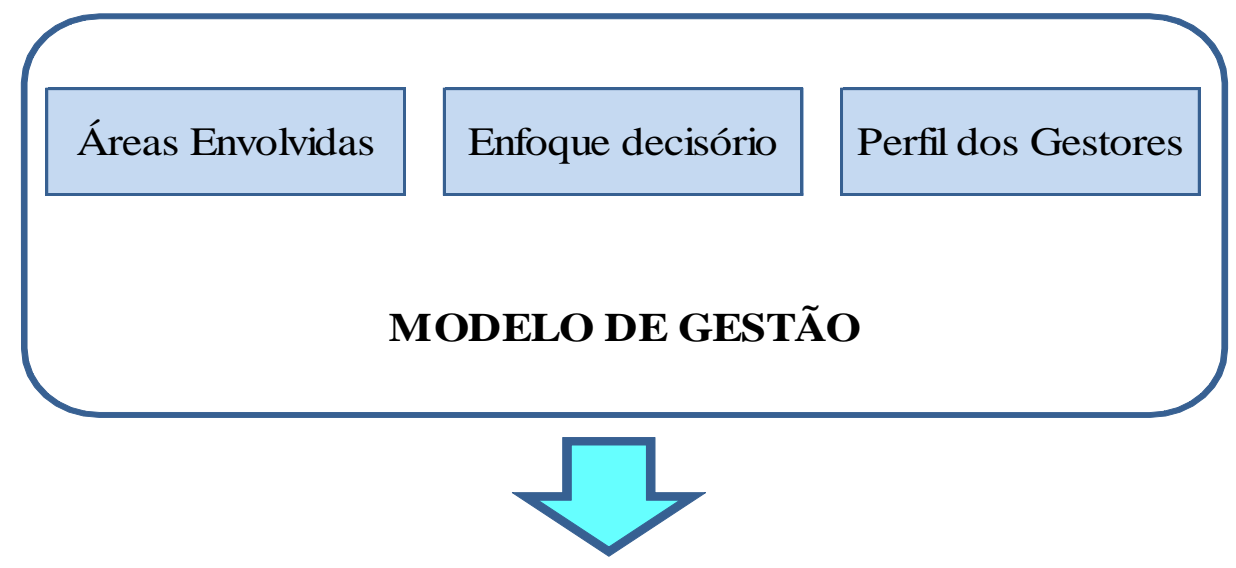

Decisões e Direcionamentos

Ilustração 2 - Modelo de Gestão

\subsection{Elementos da gestão e controle dos fluxos de caixa}

Como supracitado, o modelo de gestão influenciará o processo de decisão e os seus direcionamentos. Deste modo, seguindo as diretrizes do modelo, as decisões serão pautadas em elementos de um processo estabelecido. Como exemplo destes elementos, Frezatti (1997) destaca itens importantes para a mensuração e controle dos fluxos de caixa, entre eles: granularidade, arquitetura de sistemas, metodologia de projeção, fontes de informação e formatação de relatórios, sendo muitos destes elementos ressaltados por outros estudos. 
A metodologia de projeção é quase unanimidade nos estudos acerca das práticas de gestão e controle dos fluxos de caixa. Assim como Frezatti (1997), outros estudos científicos como os de Soenen (1986), de Kytönen (2004), de Iturralde, Maseda e San-Jose (2009) abordam esse elemento. Nestes estudos foram abordadas as metodologias de projeção, sendo estas mais simplificadas ou utilizando alguma técnica quantitativa; a sua periodicidade; e até mesmo a participação de artefatos gerenciais, como o orçamento, nestas projeções. Deste modo, sintetizando este elemento, a metodologia de projeção, quer seja ela mais simplificada, quer use programação linear, métodos quantitativos diversos, ou orçamento retificado por rolling forecast, é um elemento de grande importância para a gestão e controle dos fluxos de caixa e provavelmente seja influenciado por variáveis contextuais de acordo com o ciclo de vida organizacional, alvo de análise no decorrer deste estudo.

Outro importante ponto abordado é a tecnologia, ou seja, uma possível sistematização do processo de mensuração e controle dos fluxos de caixa pela utilização de softwares (PHILLIPS, 1997; SOENEN, 1986; FREZATTI, 1997). Além dos estudos científicos acerca da gestão do caixa, bibliografias consolidadas acerca da gestão bancária, como o trabalho de Hempel e Simonson (1998), também confirmam a importância da tecnologia ao cogitar a existência de diversas soluções de software disponíveis para gerir a liquidez, além das soluções proprietárias criadas por alguns bancos. Frezatti (1997) ressalta a importância de mapear e analisar a arquitetura de sistemas, identificando todos os envolvidos, bem como eventuais oportunidades de melhoria, de modo que a tecnologia possa ser um aliado do processo de gestão e controle dos fluxos de caixa. Seguindo ainda esta linha de raciocínio, Frezatti (1997) ressalta também a importância de se escolher as fontes de informações adequadas para que o processo de gestão discorra da maneira mais adequada possível, sem entraves e escassez informacional.

Ressaltando estes pontos, é de suma importância que as fontes utilizadas no controle de caixa sejam as mais adequadas, fidedignas, íntegras e sem duplicidade, e que possuam a quantidade e qualidade de informação necessária para atender às necessidades. A solução sistêmica precisa ainda ser conhecida, difundida, isenta de falhas operacionais, tempestiva e flexível, de modo que a solução possa de fato ser útil para o processo de gestão e controle. Do mesmo modo que os itens anteriores, este elemento tecnológico possivelmente é distinto entre as instituições e essa distinção provavelmente possua alguma relação com os estágios do ciclo de 
vida organizacional a ser colocada em cheque no decorrer deste trabalho científico com o banco em análise.

Outro importante item a ser considerado é o elemento informacional, que compreende o nível de detalhe no qual a informação é acompanhada, bem como a apresentação desta informação por meio de relatórios gerenciais. No que tange à granularidade, Frezatti (1997) cita a importância da definição de um plano de contas comum para acumulação das informações de fluxos de caixa. Expandindo esta discussão, a granularidade pode ser representada ainda por produtos, segmentos, regiões geográficas, ou seja, qualquer indicador considerado útil pela gestão para acumular os fluxos de caixa. A lógica de construção pede níveis de alta granularidade para atender às necessidades de análise, porém com possibilidade de agrupamento para níveis mais sintéticos.

A apresentação, não menos importante, se beneficiará da granularidade, pois esta poderá auxiliar na formatação de relatórios, em diversas dimensões, das mais analíticas às mais sintéticas, atendendo à especificidade de um analista até a generalidade de um executivo. $\mathrm{O}$ elemento informacional pode possuir papel determinante na boa aceitação de determinado processo de gestão e controle dos fluxos de caixa, pois granularidade e relatórios adequados às necessidades dos gestores podem ensejar uma maior utilização. No entanto, como cada banco está sujeito a um grupo de necessidades, muito provavelmente não haja um único modelo ótimo, mas sim alguns modelos ótimos, sendo esta necessidade influenciada por outras variáveis contextuais, que possivelmente possuam alguma ligação com estágio da instituição no ciclo de vida organizacional.

Sendo assim, reunindo o elemento técnico, que compreende a forma, sofisticação e periodicidade de projetar os fluxos de caixa; o elemento tecnológico, que compreende as fontes de informação e os sistemas que processam e acumulam os fluxos de caixa; e o elemento informacional que agrega a granularidade de acompanhamento das informações de fluxos de caixa e a forma de apresentação dos relatórios, forma-se o conjunto de elementos técnicos, tecnológicos e informacionais que são elementos essenciais para o processo de gestão e controle dos fluxos de caixa. A figura a seguir objetiva sintetizar esta seção de forma gráfica. 


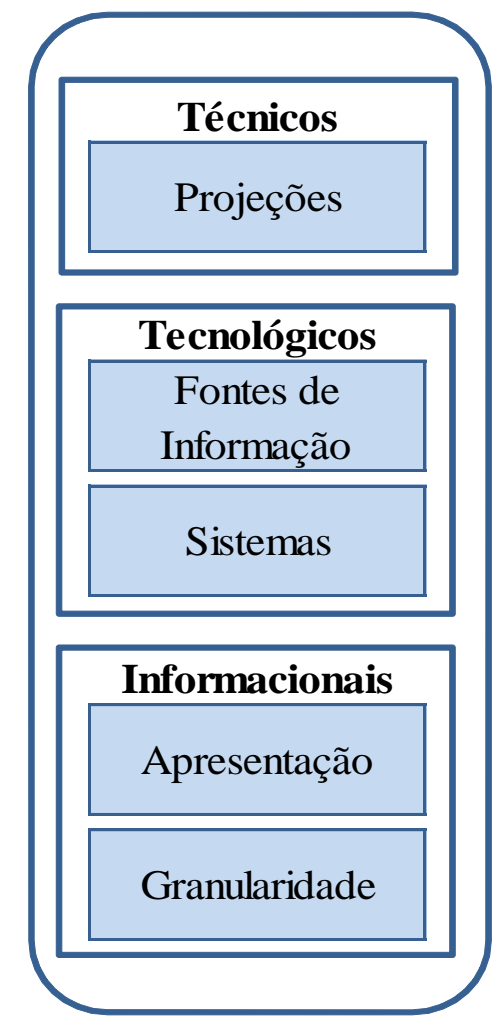

Ilustração 3 - Elementos técnicos, tecnológicos e informacionais

Os elementos supracitados integram o alicerce do processo de gestão e controle dos fluxos de caixa, variando a intensidade e completude destes elementos em cada instituição.

\subsection{Proposta da constituição do processo de gestão e controle dos fluxos de caixa}

Agrupando os itens abordados nas duas seções anteriores, tem-se a proposição que o processo de gestão e controle dos fluxos de caixa tem a forma a seguir descrita e que, de algum modo, por seus elementos, sendo estes técnicos, tecnológicos e informacionais, bem como pelo modelo de gestão, podem possuir interferência na forma como esse artefato é utilizado na prática, e em sua real finalidade e importância para a gestão da instituição. A figura seguinte pretende esquematizar esta construção. 


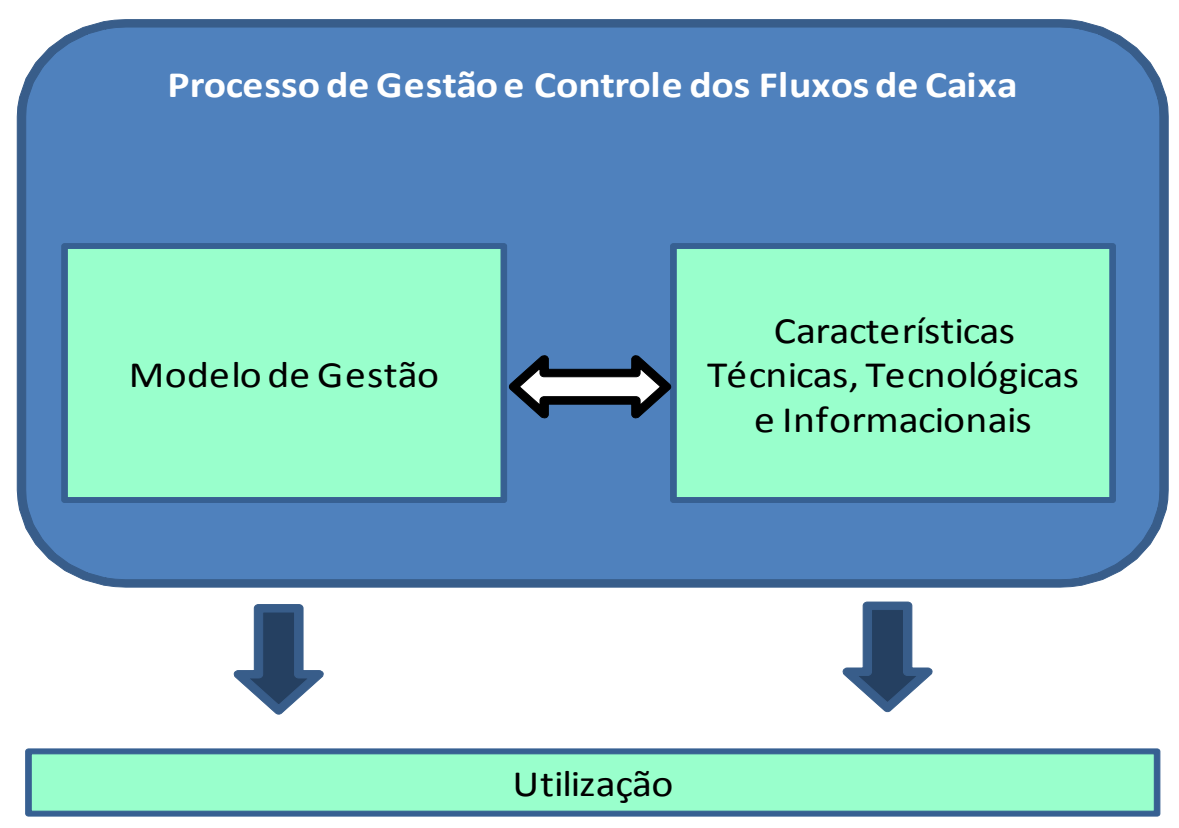

Ilustração 4 - Processo de gestão e controle dos fluxos de caixa

\subsection{Interação entre o contexto e o processo de gestão e controle dos fluxos de caixa}

No entanto, tanto as variáveis do processo de gestão e controle dos fluxos de caixa, como a sua utilização devem ser contextualizados, pois a utilização de uma única montagem ótima de fatores parece não ser cabível frente à diversidade de estratégias, estruturas, ambiente de atuação, tamanho, ambiente de controle, entre outros fatores contextuais presentes e influentes nas instituições a serem analisadas. Assim, torna-se necessária uma abordagem que leve em consideração o agrupamento destas variáveis contextuais, bem como a sua influência nos artefatos de controle, que auxilie a explicar por que a montagem delineada nas últimas seções difere entre as instituições ou grupo de instituições.

Estas afirmações são corroboradas pelos estudos de Iturralde, Maseda e San-Jose (2008, 2009) e Ozkan e Ozkan (2004) que tentam correlacionar área, setor de atuação, filosofia e cultura de gestão, tamanho da instituição, e formas de controle com a prática de gestão de caixa. A abordagem escolhida para auxiliar na tarefa de explicar o relacionamento a seguir esquematizado é a abordagem do ciclo de vida organizacional como descrita anteriormente. 


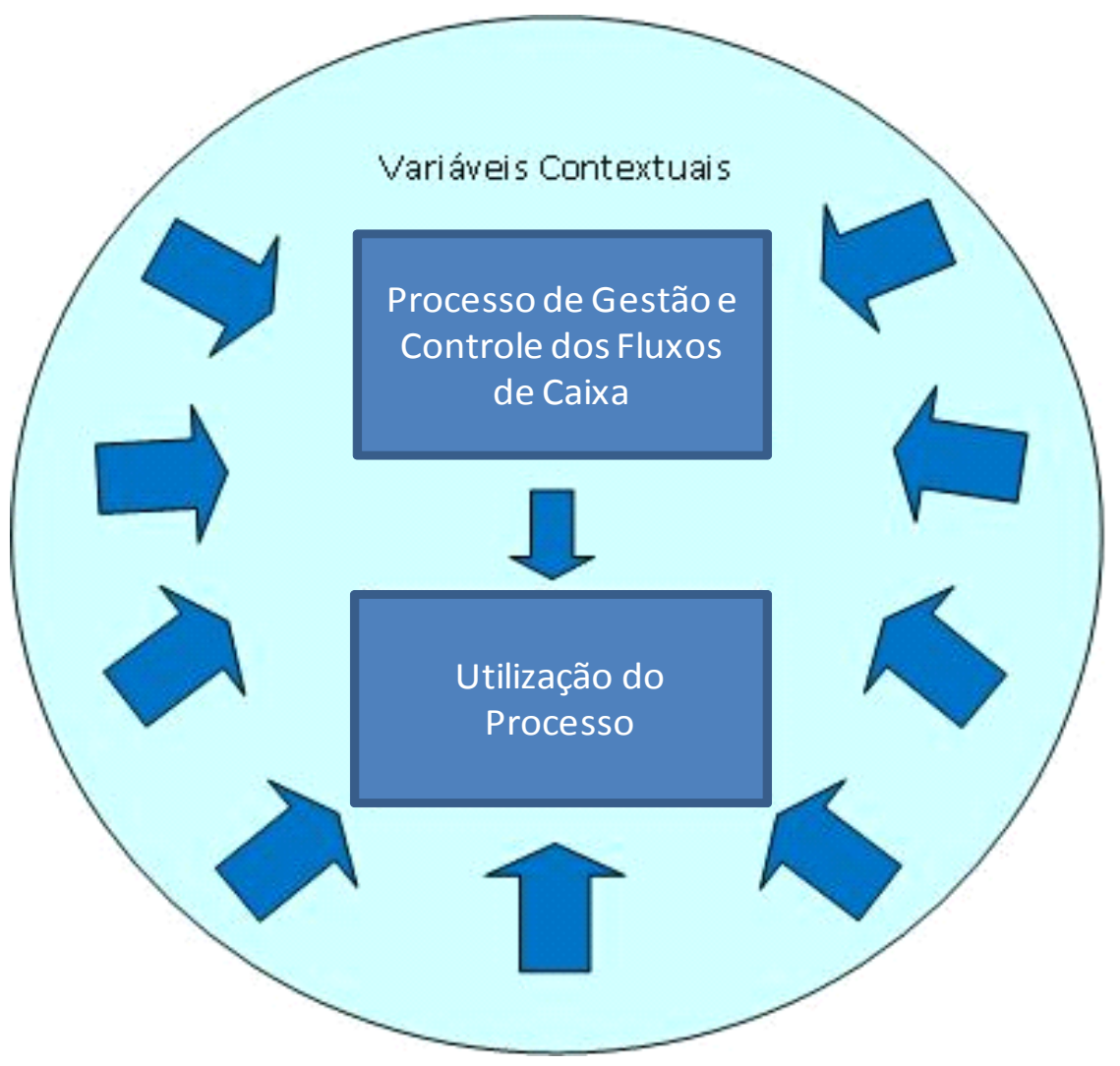

Ilustração 5 - Modelo de análise proposto ao problema

Deste modo, conforme ilustrado acima, o processo de gestão e controle dos fluxos de caixa, bem como sua utilização são variáveis que supostamente são influenciadas pelas variáveis contextuais, sendo o processo e sua utilização relevantes para o estudo, por representarem a forma com que este instrumento se apresenta na organização analisada e a finalidade para a qual é aplicado nos processos decisórios dos gestores nas diversas áreas da organização. Por sua vez, a abordagem do ciclo de vida organizacional relevante é para compreender como o contexto interfere no processo e na sua utilização.

A inferência que se faz quanto à relação entre esses elementos é que os elementos contextuais influenciam a formatação e a finalidade, pois em função do contexto em que a instituição está inserida, ela moldará seu processo de gestão e controle dos fluxos de caixa para atender a suas necessidades. Por sua vez, a lógica depreende que a formatação do processo também influencie de alguma forma a utilização do processo, pois os elementos presentes nas características do processo de gestão e controle dos fluxos de caixa, de algum modo, farão 
com que este processo seja mais ou menos aceito pelos gestores e se faça mais ou menos presente nas decisões.

\subsection{Delineamento do construto norteador}

Compilando todas as etapas relatadas pode-se afirmar que as características do processo serão delineadas pelos elementos citados anteriormente, sendo estes a técnica de projeção; a tecnologia composta pelas fontes de informação e os softwares e ou ferramentas tecnológicas; a capacidade informacional dada pelo nível de detalhe das informações e a forma de apresentação destas; bem como pela formatação do modelo de gestão, composto pelo enfoque decisório, envolvimento e perfil da gestão, exercendo esse uma possível influência nas características anteriormente citadas. Desse modo, para compreender o processo, serão analisados como e com que profundidade estão dispostos estes elementos na instituição analisada.

No que tange à utilização, serão consideradas a participação das áreas na formatação do controle, pois teoricamente quanto maior a participação consequentemente maior o envolvimento; a periodicidade das discussões para acompanhamento, pois, possivelmente, quanto mais tempestiva e menos espaçada forem as análises e discussões, maior poderá ser o senso de importância e confiabilidade. Não menos importante é a dimensão do impacto causado pela utilização das ferramentas presentes no processo. Quanto mais relevante for o impacto identificado, podendo ele, por exemplo, impactar indicadores de desempenho de uma área, de um gestor ou até mesmo a remuneração variável, maior será a importância e utilidade destinada ao processo.

A estes dois blocos se somará o contexto em que a instituição está inserida, pois este, de algum modo, influenciará o processo de gestão e controle dos fluxos de caixa e sua utilização, sendo esta análise realizada pela ótica da abordagem do ciclo de vida organizacional. Assim, não obstante o caráter exploratório da pesquisa, alguma relação entre as variáveis é esperada $a$ priori e, ao final, hipóteses relacionadas à análise deverão ao menos ser sugeridas para embasar pesquisas futuras e contribuir para ampliar o entendimento da temática. A relação suposta entre essas variáveis está indicada na Ilustração 6. 


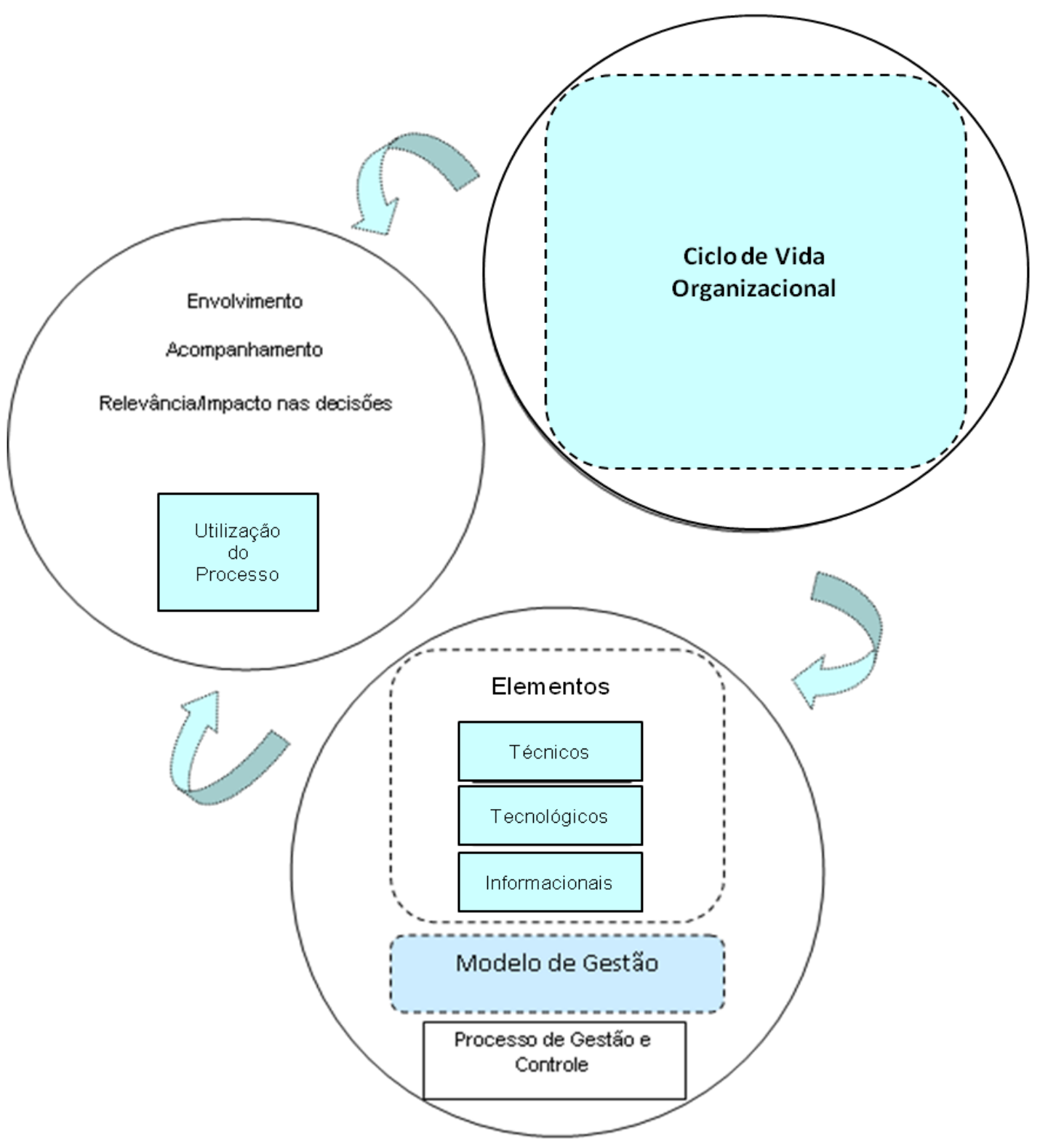

Ilustração 6 - Construto proposto de relacionamento entre as variáveis

Desse modo, a construção teórica anteriormente descrita, tanto nas subseções como nas ilustrações, permeará o percurso metodológico, os instrumentos de coleta, bem como as análises vindouras que serão realizadas neste estudo, possuindo a função de um background teórico para o estudo, reunindo a abordagem teórica do ciclo de vida organizacional, os estudos científicos e a bibliografia consolidada acerca da gestão e controle dos fluxos de caixa, bem como as interações e relacionamentos aqui vislumbrados. 


\section{PERCURSO METODOLÓGICO}

\subsection{Considerações metodológicas introdutórias: aspectos gerais e escolhas realizadas}

Conforme citado anteriormente, pretendeu-se neste estudo empírico, pela ótica da investigação e análise da prática, compreender como está delineado o processo de gestão e controle dos fluxos de caixa, processo este possuidor de tão grande relevância para a gestão bancária. Outra pressuposição orientadora do estudo está embasada no fato de que possivelmente este processo seja distinto para cada instituição ou para determinados grupos de instituições, variando de acordo com o seu estágio no ciclo de vida organizacional.

Para analisar em profundidade todos os aspectos apontados nos construtos apresentados na seção anterior, optou-se, como estratégia de pesquisa, por realizar um estudo de caso único em um banco brasileiro, que apresentasse a totalidade ou a maioria dos pontos levantados, de modo que fosse possível identificar as variáveis que caracterizam seu processo de gestão e controle dos fluxos de caixa, as variáveis que possam caracterizar a finalidade efetiva deste processo, e também que se pudesse enquadrá-la em um dos ciclos de vida organizacional de acordo com a abordagem teórica escolhida, promovendo uma reflexão sobre o relacionamento destas variáveis.

Esta construção se mostra pioneira ao propor a classificação de um banco num modelo que tem sido utilizado para classificar instituições não financeiras, e por explorar em profundidade a temática da prática da gestão do caixa que, conforme já citado, não tem sido muito explorada em pesquisas científicas (KYTÖNEN, 2004). Este ineditismo se configura em uma das contribuições deste estudo.

A escolha de uma única instituição se deve basicamente a três grandes motivos: por se propor a analisar a prática do processo de gestão e controle dos fluxos de caixa e sua finalidade, a pesquisa necessita de profundidade, para compreender o delineamento e o interrelacionamento das variáveis que o formam, sendo a obtenção dessa profundidade possível somente com foco em poucas ou em uma única instituição; por se tratar de um estudo 
exploratório com certo pioneirismo, necessitando, portanto, de um aprofundamento inicial antes que esta possa fomentar pesquisas que intentem generalização estatística; e finalmente pela dificuldade de sensibilização simultânea de várias instituições, em função de a temática ser tratada como estratégica e confidencial, causando certo temor de exposição e dificuldade na coleta dos dados necessários para a realização da pesquisa.

Foi realizada a escolha de um banco que pudesse ser complexo o bastante para conter muitas das variáveis e interações vislumbradas nos construtos da seção 6 , sendo essa uma unidade social adequada para o propósito exploratório deste estudo. No entanto, mesmo sem possibilidade de generalização estatística, esta pesquisa poderá contribuir para a formação de um modelo que poderá ser testado em outros bancos, tanto em pesquisas científicas, como na prática empresarial, e até mesmo servir de subsídio para novas pesquisas confirmatórias ou contraditórias. Para que esta utilização seja possível, tanto esta seção como as demais terão a finalidade de trazer a maior transparência possível quanto aos métodos e etapas utilizadas na pesquisa, para que esta possa ser reproduzida e ou aprimorada.

A opção pela estratégia de pesquisa do estudo de caso foi realizada levando-se em conta as considerações de Yin (2010) que afirma que o estudo de caso é o método preferido quando o pesquisador tem pouco controle sobre os eventos, e quando o enfoque está num fenômeno contemporâneo no contexto da vida real. Especificamente com relação a este estudo, pretende-se compreender o processo de gestão de caixa pela abordagem do ciclo de vida organizacional, pela análise da prática desenvolvida em um banco brasileiro, sendo esta uma temática contemporânea, prática, e pautada na observação da vida real.

Já para Martins e Theóphilo (2009), o estudo de caso consiste no estudo de uma unidade social que se analisa e aprofunda intensamente, por meio de uma investigação empírica na qual o pesquisador busca de forma criativa compreender, descrever e interpretar a complexidade de um caso concreto. Esta afirmação também reflete o intento deste estudo, uma vez que compreender, analisar e interpretar o delineamento de um processo tão complexo quanto o de gestão e controle dos fluxos de caixa num banco, pela ótica da abordagem do ciclo de vida organizacional, é o principal objetivo deste estudo.

Ainda segundo Yin (2010), para que um estudo de caso possa ser bem sucedido e consiga superar eventuais preconceitos de sua utilização em detrimento de outras estratégias de 
pesquisa, alcançando, portanto, sua finalidade como estratégia de investigação empírica, é necessário que este possua rigor e transparência nos passos seguidos para obtenção de suas evidências, possibilitando a validade e a confiabilidade dos achados; é importante que ele permita expandir e ou generalizar teorias, ou seja, propiciar generalização analítica, apesar de não ser passível de generalização estatística, em função de ser o estudo de uma única unidade social; é de suma importância que a sua realização não seja demasiadamente prolongada e que a sua redação seja sucinta e fluída. No entanto, tanto Yin (2010) como Bryman (2008) confirmam que a habilidade, criatividade e condução do pesquisador são fundamentais para o sucesso de um estudo de caso.

Partindo da estratégia de pesquisa supracitada com o intuito de explorar o delineamento do processo de gestão e controle dos fluxos de caixa, sua utilização e seu relacionamento com o ciclo de vida organizacional, definiu-se o público alvo da pesquisa, sendo este composto pelas equipes e os gestores envolvidos na gestão e controle de caixa e ou de liquidez. Na instituição em análise, as áreas representantes abrangidas pelo estudo são a gestão corporativa de finanças, a gestão corporativa de riscos e a gestão de tesouraria.

A escolha das áreas foi uma tarefa que procurou buscar as principais áreas envolvidas na gestão e controle dos fluxos de caixa, sendo a tesouraria a responsável de fato pela gestão de caixa e dos seus fluxos, bem como pela interlocução, negociação e discussão com as áreas aplicadoras e captadoras de recursos; a área de risco, a responsável por auxiliar na gestão com o desenvolvimento de análises, limites e políticas focadas na gestão do risco de liquidez; e a área de finanças que é responsável pela disponibilização e preparação de informações acerca dos fluxos de caixa, bem como na interlocução com as áreas de negócios, na elaboração de análises relevantes e na integração da visão caixa com a visão de resultados, retornos e risco.

Já com relação às equipes e pessoas, buscou-se em cada uma dessas áreas as pessoas que estivessem bastante envolvidas com o processo de gestão e controle dos fluxos de caixa, quer na preparação, organização e análise de informações, quer na condução do processo decisório e deliberação das diretrizes acerca do caixa. Desta forma, para captar aspectos práticos acerca do processo, de sua utilidade e do ciclo de vida organizacional da instituição buscou-se questionar os membros da organização mais próximos a estas temáticas, contrapondo e ou confirmando essas percepções pelo questionamento dos gestores gerais desses colaboradores, 
que possuem outras atividades além da gestão do caixa, sendo assim, possuidores também de uma visão mais estratégica da temática a ponto de trazer uma visão crítica aos aspectos práticos captados juntos aos colaboradores indagados inicialmente.

Para operacionalizar este estudo de caso foram trilhadas as seguintes etapas: coleta de dados inicial por meio de questionários disponibilizados em formulário eletrônico; coleta de dados complementar realizada por meio de entrevistas semiestruturadas; análise dos achados, contemplando a utilização de ferramentas estatísticas, triangulação dos dados, e discussão das conclusões preliminares com os participantes; e finalmente redação definitiva das conclusões incorporando o resultado das discussões ocorridas na etapa anterior.

Em linhas gerais, a primeira etapa, viabilizada pelo questionário em formulário eletrônico, tem por objetivo coletar a percepção das pessoas envolvidas de fato na definição e delineamento do processo de gestão e controle dos fluxos de caixa acerca das diversas variáveis formadoras dos construtos expostos na seção 6. A segunda etapa tem por objetivo complementar, ressaltar ou até mesmo contrapor os achados da primeira etapa pela coleta da percepção dos gestores gerais, sendo esta fase operacionalizada pelas entrevistas semiestruturadas. A penúltima etapa compreende todo o trabalho de processamento dos achados e discussão das inferências acerca das informações produzidas a partir das duas primeiras etapas. Por fim se dará a redação do relatório final desta pesquisa. O detalhamento de cada uma dessas etapas será descrito nas seções subsequentes, de modo a promover transparência necessária para futuras utilizações e aprimoramentos da metodologia.

\subsection{Cronologia do estudo}

O quadro abaixo demonstrará cada etapa desenvolvida para a realização deste estudo, posicionando-a no tempo, indicando em que mês e ano ela foi iniciada, e em que mês e ano ela foi concluída, demonstrando de que modo o tempo foi despendido em cada um das tarefas, como o trabalho evoluiu, e as etapas que consumiram mais tempo na realização desta pesquisa. O cronograma tem início em abril de $2011 \mathrm{com}$ as primeiras ideias do estudo e com a primeira versão do pré-projeto de pesquisa, e tem seu fim em julho de 2012 com a redação final deste documento. 
Quadro 2 - Cronologia do estudo

\begin{tabular}{|c|c|c|c|c|c|c|c|c|c|c|c|c|c|c|c|c|}
\hline \multirow{2}{*}{ CRONOGRAMA } & \multicolumn{9}{|c|}{2011} & \multicolumn{7}{|c|}{2012} \\
\hline & $\mathrm{abr}$ & mai & jun & jul & ago & set & out & nov & $\mathrm{dez}$ & jan & fev & mar & $a b r$ & mai & jun & ju \\
\hline Elaboração do pré projeto & $\mathrm{X}$ & $\mathrm{X}$ & & & & & & & & & & & & & & \\
\hline Referencial teórico e fundamentação inicial & $\mathrm{X}$ & $\mathrm{X}$ & $\mathrm{X}$ & $\mathrm{X}$ & $\mathrm{X}$ & $\mathrm{X}$ & & & & & & & & & & \\
\hline Elaboração da primeira versão do questionário & & & & $\mathrm{X}$ & $\mathrm{X}$ & $\mathrm{X}$ & & & & & & & & & & \\
\hline Qualificação do projeto de pesquisa & & & & & & $\mathrm{X}$ & & & & & & & & & & \\
\hline Referencial teórico e fundamentação & & & & & & & $\mathrm{X}$ & $\mathrm{X}$ & $\mathrm{X}$ & $\mathrm{X}$ & $\mathrm{X}$ & $\mathrm{X}$ & $\mathrm{X}$ & $\mathrm{X}$ & $\mathrm{X}$ & $\mathrm{X}$ \\
\hline Inclusão das sugestões advindas da qualificação & & & & & & & $\mathrm{X}$ & $\mathrm{X}$ & $\mathrm{X}$ & $\mathrm{X}$ & & & & & & \\
\hline Revisão e reformulação do questionário & & & & & & & & & & & $\mathrm{X}$ & $\mathrm{X}$ & & & & \\
\hline Realização do pré-teste do questionário & & & & & & & & & & & & $\mathrm{X}$ & & & & \\
\hline Viabilização da pesquisa & & & & & & & & $\mathrm{X}$ & $\mathrm{X}$ & $\mathrm{X}$ & $\mathrm{X}$ & $\mathrm{X}$ & $\mathrm{X}$ & & & \\
\hline Envio do questionário aos participantes & & & & & & & & & & & & & $\mathrm{X}$ & & & \\
\hline Recebimento das respostas ao questionário & & & & & & & & & & & & & & $\mathrm{X}$ & & \\
\hline Construção da base de dados do questionário & & & & & & & & & & & & & & $\mathrm{X}$ & & \\
\hline Realização das entrevistas & & & & & & & & & & & & & & $\mathrm{X}$ & & \\
\hline Processamento e análise das informações & & & & & & & & & & & & & & $\mathrm{X}$ & $\mathrm{X}$ & \\
\hline Discussões e redação das conclusões encontradas & & & & & & & & & & & & & & $\mathrm{X}$ & $\mathrm{X}$ & \\
\hline Finalização e revisão do documento final & & & & & & & & & & & & & & & $\mathrm{X}$ & $\mathrm{X}$ \\
\hline
\end{tabular}

\subsection{Protocolo do estudo de caso}

Na sequência será apresentada uma figura que tem o intuito de representar o protocolo deste estudo de caso. A figura abrangerá as etapas de coleta e análise dos dados, bem como a etapa de construção teórica. A representação gráfica auxilia a visualizar as etapas que serão descritas em detalhes nas seções seguintes.

O protocolo abaixo está dividido em quatro etapas, sendo a primeira, uma etapa prévia, porém contínua no que tange à fundamentação, denominada de viabilização e fundamentação teórica. A fundamentação teórica está presente ao longo de todo o trabalho e a viabilização é a atividade que compreendeu o contato com órgãos de classe, associações e instituições com intuito de identificar possíveis participantes para o estudo.

As demais fases compreendem a execução da pesquisa após a definição da instituição participante, passando pela etapa de coleta e análise dos dados via questionário aplicado aos 
colaboradores e gestores participantes; pela etapa de entrevistas com os gestores gerais; e pela etapa de triangulação e discussão dos dados obtidos nessas duas fases, e pela conseguinte redação das conclusões e considerações advindas da reflexão acerca dos achados da pesquisa.

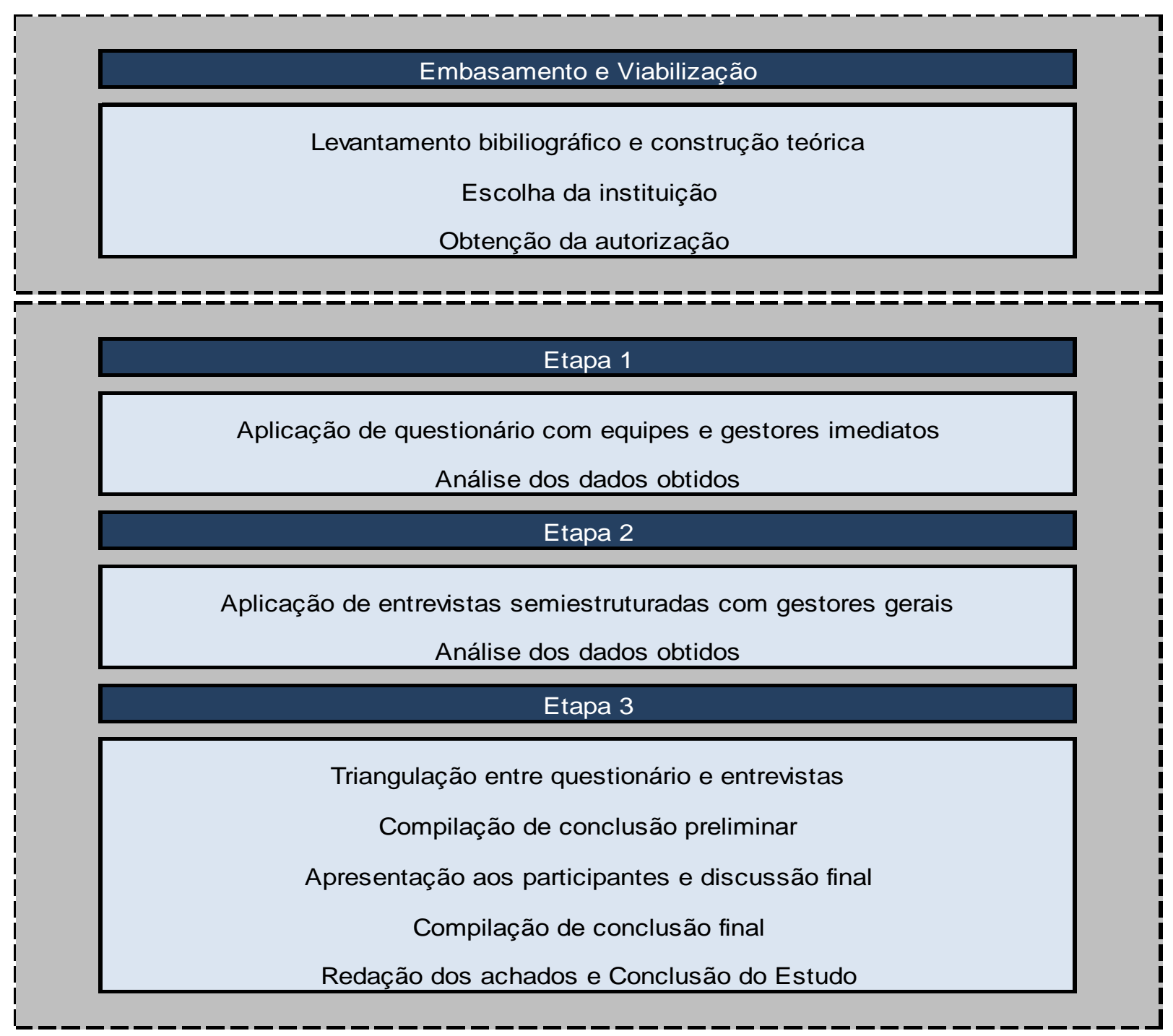

\section{Ilustração 7 - Protocolo do estudo de caso}

As seções seguintes descreverão em maiores detalhes as etapas 1, 2 e 3 desta pesquisa.

\subsection{Questionário: referencial e delineamento}

A etapa 1 consistiu em um questionário que, segundo Martins e Theóphilo (2009), é um importante e popular instrumento de coleta de dados para uma pesquisa social, sendo este um 
levantamento das percepções dos pesquisados com o intuito de identificar o relacionamento das variáveis representativas do processo de gestão e do ciclo de vida organizacional definidas e evidenciadas anteriormente. Este questionário disponibilizado em meio eletrônico contou com a participação de dezoito respondentes.

Para possibilitar uma melhor comparação, agrupamento e relacionamento entre as variáveis, o questionário é composto quase em sua totalidade por questões fechadas, sendo que a maioria utiliza a escala Likert-5 como parâmetro, e as demais questões são de múltipla escolha. Pelo ganho advindo da comparabilidade e possibilidade de agrupamento, pretendeu-se superar as desvantagens apontadas por Bryman (2008) às questões fechadas como, por exemplo, a limitação de expressão pessoal por parte do respondente.

Do mesmo modo, a confecção do questionário procurou seguir os princípios gerais que devem nortear sua elaboração, como observado por Bryman (2008), que afirma que o pesquisador deve identificar o que se deseja saber e como responder a esta dúvida, observando também a tentativa de não redigir termos ambíguos em questões, não exagerar no tamanho, nem elaborar questões com duas vertentes de interpretação.

Considerando os objetivos propostos para o estudo, foram pesquisadas três macro variáveis: (1) processo de gestão e controle dos fluxos de caixa nos bancos, compostos pelos elementos e pelo modelo de gestão; (2) utilização do processo de gestão e controle dos fluxos de caixa; (3) características organizacionais determinantes dos estágios no ciclo de vida organizacional da instituição em análise. Dado o caráter exploratório da pesquisa, não são propostas hipóteses para serem testadas.

Para a pesquisa dessas variáveis, é proposto um conjunto de questões visando a refletir o melhor possível suas diversas dimensões. Essas questões têm a função de refletir os construtos apresentados na seção 6, permitindo discernir as diversas facetas do processo de gestão e controle dos fluxos de caixa tendo como instrumento de coleta o questionário apresentado no Apêndice 1. A proposição dessas questões segue uma abordagem dedutiva, haja vista o esforço para refletir os construtos de processo, utilização, e ciclo de vida organizacional, conforme conceituação teórica. 


\subsubsection{Dimensões características do processo de gestão e controle dos fluxos de caixa, de sua utilização e do estágio no ciclo de vida organizacional}

A formatação do processo de gestão e controle dos fluxos de caixa pode ser caracterizada de acordo com os itens anteriormente depreendidos: modelo de gestão e elementos técnicos, tecnológicos e informacionais. O modelo de gestão é a variável que procurará captar a influência da filosofia e orientação da gestão sobre o processo de gestão do caixa. Para captar essa percepção, questiona-se sobre a natureza das decisões, sobre o papel e envolvimento dos gestores no processo decisório, sobre a centralização do modelo decisório, bem como sobre a formulação e execução de políticas e modelos estruturados de gestão e controle de caixa.

Quanto aos elementos, inicialmente no que tange ao grupo informacional e tecnológico, se buscará identificar quão granulares são as informações acompanhadas de fluxos de caixa, quão padronizadas ou customizadas são estas informações apresentadas aos usuários, quão íntegras e concentradas são as fontes de informação utilizadas, qual o nível de utilização de softwares no processamento e extração destas informações e quão completos eles são, e por fim o quão difundido é o fluxo de informações entre os participantes do processo de gestão e controle dos fluxos de caixa. Já no que tange ao grupo técnico, serão exploradas as técnicas utilizadas para projetar os fluxos de caixa, sendo estas mais ou menos sofisticadas, bem como o horizonte e a frequência de atualização destas projeções.

Finalmente em relação à utilização do processo de gestão e controle dos fluxos de caixa, buscar-se-á captar a influência desse instrumento sobre processos decisórios da instituição, como é realizado o acompanhamento das projeções realizadas versus as previstas, e verificar a possível participação das informações de fluxos de caixa na formulação das métricas de avaliação de desempenho presentes na instituição em análise. As questões utilizadas para coletar essas informações estão dispostas nos Blocos B, C e D do questionário presente no Apêndice 1.

A caracterização do estágio no ciclo de vida organizacional estará presente em um dos blocos de questões, sendo estas questões advindas do trabalho desenvolvido por Lester, Parnell e Carraher (1993) com algumas adaptações realizadas para este estudo. A finalidade desse bloco é enquadrar a instituição em análise em um dos estágios do ciclo de vida 
organizacional, para que posteriormente se analise a relação entre as características de ciclo e as características do processo de gestão e controle dos fluxos de caixa.

O modelo básico de classificação dos estágios no ciclo de vida organizacional, previamente testado em outro estudo, foi elaborado por Lester, Parnell e Carraher (1993) com base nas dimensões organizacionais descritas por Miller e Friesen (1984): estratégia, estrutura organizacional, estilo para tomadas de decisões e situação organizacional. O instrumento de mensuração contém questões adaptadas que pretendem enquadrar a instituição em um dos cinco estágios descritos: existência, sobrevivência, sucesso, renovação e declínio.

As questões versam sobre temáticas como tamanho relativo da instituição, controle acionário e estrutura, direcionamento estratégico, processo decisório, ambiente no qual a instituição está inserida, processamento de informações, eficiência e desempenho. Pela gradação dessas características, o banco em análise será enquadrado em um dos estágios do ciclo de vida organizacional propostos por Lester, Parnell e Carraher (1993). Para essa caracterização, são sugeridas as questões apresentadas no Bloco E do questionário presente no Apêndice 1.

\subsubsection{Embasamento teórico das questões}

Os blocos de questões e suas respectivas temáticas conforme supracitado estão relacionados ao referencial de diversos autores citados ao longo deste trabalho. De modo a sintetizar as contribuições, foi elaborado o quadro sinótico abaixo apresentado.

Sendo assim, o quadro relaciona cada questão referida no questionário constante no Apêndice 1 com os autores que as motivaram, de modo a trazer maior transparência e fundamentação para cada questão presente neste estudo de caso, permitindo futuros aprimoramentos, reproduções em outros contextos, ou mesmo contraposições.

Quadro 3 - Relação de autores, temáticas e questões

\begin{tabular}{|l|c|c|}
\hline Questão & Conceito Geral & Autores (Referências) \\
\hline & GRUPO DE CONTROLE & Sem Autor \\
\hline 1. Sexo & Variável de Controle & \\
\hline
\end{tabular}




\begin{tabular}{|c|c|c|}
\hline \multicolumn{3}{|c|}{ GRUPO DE CONTROLE } \\
\hline 2. Tempo na Instituição (em anos) & Variável de Controle & Sem Autor \\
\hline 3. Área a qual pertence & Informativo & Sem Autor \\
\hline \multicolumn{3}{|c|}{ GRUPO TÉCNICO } \\
\hline $\begin{array}{c}\text { 4. As decisões tomadas nos eventos } \\
\text { de acompanhamento formal de gestão } \\
\text { e controle de fluxos de caixa em sua } \\
\text { organização impactam ... }\end{array}$ & $\begin{array}{l}\text { Tipo de decisão tomada com as } \\
\text { informações de fluxo de caixa }\end{array}$ & $\begin{array}{c}\text { Frezatti (1997), Phillips (1997) e } \\
\text { Kytönen (2004) }\end{array}$ \\
\hline $\begin{array}{l}\text { 5. Em relação ao processo de gestão e } \\
\text { controle dos fluxos de caixa } \\
\text { desenvolvido em sua organização, os } \\
\text { gestores das áreas de negócios são } \\
\text { responsáveis pelas projeções... }\end{array}$ & $\begin{array}{l}\text { Postura dos gestores em relação ao } \\
\text { processo de gestão e controle dos } \\
\text { fluxos de caixa }\end{array}$ & $\begin{array}{c}\text { Frezatti (1997) e lturralde, Maseda e } \\
\text { San-Jose }(2008,2009)\end{array}$ \\
\hline $\begin{array}{l}\text { 6. Sua organização possui política de } \\
\text { liquidez, acompanhamento do risco de } \\
\text { liquidez, bem como... }\end{array}$ & Política de gestão de risco de liquidez & Phillips (1997) e Bessis (1998) \\
\hline $\begin{array}{c}\text { 7. Sua organização se utiliza } \\
\text { unicamente de equipes internas } \\
\text { especializadas na def inição e } \\
\text { identificação de políticas, limites, riscos } \\
\text { e controles de liquidez... }\end{array}$ & Política de gestão de risco de liquidez & Phillips (1997) e Bessis (1998) \\
\hline $\begin{array}{c}\text { 8. De forma geral, em relação aos } \\
\text { gestores das áreas de negócio em sua } \\
\text { organização é possível afirmar que } \\
\text { são ativamente participantes da gestão } \\
\text { do caixa... }\end{array}$ & $\begin{array}{c}\text { Postura dos gestores em relação ao } \\
\text { processo de gestão e controle dos } \\
\text { fluxos de caixa }\end{array}$ & $\begin{array}{c}\text { Frezatti (1997) e lturralde, Maseda e } \\
\text { San-Jose }(2008,2009)\end{array}$ \\
\hline $\begin{array}{l}\text { 9. Tratando-se da gestão e do controle } \\
\text { do caixa propriamente constituídos é } \\
\text { correto afirmar que em sua } \\
\text { organização este processo é } \\
\text { descentralizado... } \\
\end{array}$ & $\begin{array}{l}\text { Centralização ou descentralização do } \\
\text { processo decisório }\end{array}$ & $\begin{array}{c}\text { Soenen (1986) e Iturralde, Maseda e } \\
\text { San-Jose (2009) }\end{array}$ \\
\hline $\begin{array}{l}\text { 10. Em sua organização os fluxos de } \\
\text { caixa são projetados e analisados de } \\
\text { forma bem analítica, sendo observadas } \\
\text { subdivisões de fluxos de caixa... }\end{array}$ & $\begin{array}{l}\text { Granularidade da informação de fluxo } \\
\text { de caixa }\end{array}$ & Frezatti (1997) e Kytönen (2004) \\
\hline $\begin{array}{l}\text { 11. Em sua organização, os relatórios } \\
\text { de fluxos de caixa apresentados às } \\
\text { áreas de negócio são todos } \\
\text { customizados, ou seja, cada relatório } \\
\text { de cada área de negócio... }\end{array}$ & $\begin{array}{l}\text { Padronização ou Customização das } \\
\text { Informações }\end{array}$ & Frezatti (1997) e Kytönen (2004) \\
\hline $\begin{array}{l}\text { 12. É possível afirmar que em sua } \\
\text { organização existem pouquíssimas ou } \\
\text { uma única fonte de informação que } \\
\text { fornece toda a informação necessária } \\
\text { para gerar a informação integral... }\end{array}$ & $\begin{array}{l}\text { Fontes de Informação e sua } \\
\text { integridade para efeito fluxo de caixa }\end{array}$ & $\begin{array}{l}\text { Soenen (1986); Frezatti (1997) e } \\
\text { Hempel e Simonson (1998) }\end{array}$ \\
\hline
\end{tabular}




\begin{tabular}{|c|c|c|}
\hline \multicolumn{3}{|c|}{ GRUPO TÉCNICO } \\
\hline $\begin{array}{l}\text { 13. O processamento, elaboração e } \\
\text { controle dos fluxos de caixa são } \\
\text { realizados totalmente ou } \\
\text { predominantemente num sistema } \\
\text { integrado... }\end{array}$ & $\begin{array}{c}\text { Sistemas de Informação para ef eito } \\
\text { fluxo de caixa }\end{array}$ & $\begin{array}{c}\text { Soenen (1986); Frezatti (1997) e } \\
\text { Phillips (1997) }\end{array}$ \\
\hline $\begin{array}{c}\text { 14. O fluxo de informações que } \\
\text { transita por meio dos sistemas e } \\
\text { ferramentas utilizados no processo de } \\
\text { gestão e controle dos fluxos de } \\
\text { caixa... }\end{array}$ & $\begin{array}{l}\text { Fontes de Informação e sua } \\
\text { integridade para efeito fluxo de caixa }\end{array}$ & $\begin{array}{l}\text { Soenen (1986); Frezatti (1997) e } \\
\text { Hempel e Simonson (1998) }\end{array}$ \\
\hline $\begin{array}{c}\text { 15. Nas projeções de fluxos de caixa } \\
\text { realizadas na sua organização são } \\
\text { utilizadas técnicas de estatística } \\
\text { avançadas como regressões, dados } \\
\text { em painel... }\end{array}$ & $\begin{array}{c}\text { Metdologias de projeção de fluxos de } \\
\text { caixa }\end{array}$ & $\begin{array}{c}\text { Soenen (1986); Frezatti (1997); } \\
\text { Kytönen (2004) e Iturralde, Maseda e } \\
\text { San-Jose (2009) }\end{array}$ \\
\hline $\begin{array}{c}\text { 16. As projeções de fluxos de caixa } \\
\text { são geradas por informações obtidas a } \\
\text { partir do processo orçamentário anual } \\
\text { do banco... }\end{array}$ & $\begin{array}{l}\text { Metodologias de projeção de fluxos de } \\
\text { caixa }\end{array}$ & $\begin{array}{c}\text { Soenen (1986); Frezatti (1997); } \\
\text { Kytönen (2004) e Iturralde, Maseda e } \\
\text { San-Jose (2009) }\end{array}$ \\
\hline $\begin{array}{c}\text { 17. Existem projeções de fluxos de } \\
\text { caixa para os seguintes horizontes } \\
\text { futuros. }\end{array}$ & $\begin{array}{l}\text { Horizonte das projeções de fluxos de } \\
\text { caixa }\end{array}$ & Iturralde, Maseda e San-Jose (2009) \\
\hline $\begin{array}{l}\text { 18. As projeções de fluxos de caixa } \\
\text { são atualizadas de acordo com as } \\
\text { seguintes periodicidades. }\end{array}$ & $\begin{array}{l}\text { Atualização das projeções de fluxos } \\
\text { de caixa }\end{array}$ & Iturralde, Maseda e San-Jose (2009) \\
\hline $\begin{array}{c}\text { 19. Existe na sua organização uma } \\
\text { estrutura formal de reunião, conselho } \\
\text { ou comitê de acompanhamento da } \\
\text { gestão... }\end{array}$ & Acompanhamento dos fluxos de caixa & $\begin{array}{l}\text { Iturralde, Maseda e San-Jose (2008, } \\
\text { 2009) }\end{array}$ \\
\hline $\begin{array}{l}\text { 20. Com relação às discussões e } \\
\text { definições geradas a partir da } \\
\text { apresentação das informações } \\
\text { referentes... }\end{array}$ & $\begin{array}{l}\text { Tipo de decisão tomada com as } \\
\text { informações de fluxo de caixa }\end{array}$ & $\begin{array}{c}\text { Frezatti (1997), Phillips (1997) e } \\
\text { Kytönen (2004) }\end{array}$ \\
\hline $\begin{array}{c}\text { 21. A análise real x previsto dos fluxos } \\
\text { de caixa gera ações de gestão } \\
\text { ef etivas, quer sejam essas corretivas } \\
\text { ou preventivas... }\end{array}$ & $\begin{array}{l}\text { Tipo de decisão tomada com as } \\
\text { informações de fluxo de caixa }\end{array}$ & $\begin{array}{c}\text { Frezatti (1997), Phillips (1997) e } \\
\text { Kytönen (2004) }\end{array}$ \\
\hline $\begin{array}{l}\text { 22. Em sua organização existem } \\
\text { indicadores de desempenho } \\
\text { relacionados à gestão e controle dos } \\
\text { fluxos de caixa... }\end{array}$ & $\begin{array}{l}\text { Relação entre fluxo de caixa e } \\
\text { avaliação de desempenho }\end{array}$ & $\begin{array}{l}\text { Iturralde, Maseda e San-Jose (2008, } \\
\text { 2009) }\end{array}$ \\
\hline $\begin{array}{l}\text { 23. Quanto ao tamanho sua } \\
\text { organização... }\end{array}$ & Ciclo de Vida Organizacional & $\begin{array}{c}\text { Lester, Parnell e Carraher (1993); Miller } \\
\text { e Friesen (1983, 1984) e Moores e } \\
\text { Yuen (2001) }\end{array}$ \\
\hline $\begin{array}{l}\text { 24. Quanto ao controle em sua } \\
\text { organização ele se encontra... }\end{array}$ & Ciclo de Vida Organizacional & $\begin{array}{l}\text { Lester, Parnell, e Carraher (1993); } \\
\text { Miller e Friesen (1983, 1984) e Moores } \\
\text { e Yuen (2001) }\end{array}$ \\
\hline
\end{tabular}




\begin{tabular}{|c|c|c|}
\hline \multicolumn{3}{|c|}{ GRUPO TÉCNICO } \\
\hline $\begin{array}{l}\text { 25. Quanto à estrutura e modelo de } \\
\text { gestão geral sua organização... }\end{array}$ & Ciclo de Vida Organizacional & $\begin{array}{c}\text { Lester, Parnell e Carraher (1993); Miller } \\
\text { e Friesen (1983, 1984) e Moores e } \\
\text { Yuen (2001) }\end{array}$ \\
\hline $\begin{array}{l}\text { 26. Quanto ao processamento de } \\
\text { informações na sua organização, pode- } \\
\text { se afirmar que... }\end{array}$ & Ciclo de Vida Organizacional & $\begin{array}{c}\text { Lester, Parnell e Carraher (1993); Miller } \\
\text { e Friesen (1983, 1984) e Moores e } \\
\text { Yuen (2001) }\end{array}$ \\
\hline $\begin{array}{l}\text { 27. Quanto ao direcionamento } \\
\text { estratégico a sua organização... }\end{array}$ & Ciclo de Vida Organizacional & $\begin{array}{c}\text { Lester, Parnell e Carraher (1993); Miller } \\
\text { e Friesen (1983, 1984) e Moores e } \\
\text { Yuen (2001) }\end{array}$ \\
\hline $\begin{array}{l}\text { 28. Quanto ao processo decisório em } \\
\text { sua organização pode-se afirmar que: }\end{array}$ & Ciclo de Vida Organizacional & $\begin{array}{c}\text { Lester, Parnell e Carraher (1993); Miller } \\
\text { e Friesen (1983, 1984) e Moores e } \\
\text { Yuen (2001) }\end{array}$ \\
\hline $\begin{array}{l}\text { 29. O ambiente comercial em que sua } \\
\text { organização está inserida pode ser } \\
\text { descrito como... }\end{array}$ & Ciclo de Vida Organizacional & Phillips (1997) \\
\hline $\begin{array}{l}\text { 30. Sua organização está satisfeita } \\
\text { com seu desempenho... }\end{array}$ & Ciclo de Vida Organizacional & $\begin{array}{c}\text { Lester, Parnell e Carraher (1993); Miller } \\
\text { e Friesen (1983, 1984) e Moores e } \\
\text { Yuen (2001) }\end{array}$ \\
\hline 31. Sua organização é eficiente. & Ciclo de Vida Organizacional & $\begin{array}{c}\text { Lester, Parnell e Carraher (1993); Miller } \\
\text { e Friesen (1983, 1984) e Moores e } \\
\text { Yuen (2001) }\end{array}$ \\
\hline
\end{tabular}

\subsubsection{Validação do instrumento e coleta}

Para validar o instrumento foi realizado um pré-teste com 7 colaboradores envolvidos no processo de gestão e controle de caixa de duas instituições distintas, seguindo a amostra de 3 a 10 colaboradores para esta fase, conforme o direcionamento de Martins e Theóphilo (2009). Este pré-teste foi realizado cerca de um mês antes da realização efetiva da pesquisa e possuiu duração de duas semanas. $\mathrm{O}$ pré-teste possibilitou aprimorar o instrumento com as contribuições valiosas dos profissionais que atuam nesse ramo, bem como atestar a confiabilidade do questionário, pelo Alfa de Cronbach. O coeficiente Alfa de Cronbach obtido foi de 0,877 ficando em um nível de confiabilidade considerado bom, com nenhuma questão abaixo de 0,86 . Os resultados das questões testadas estão no Apêndice 3, no quadro do item A.3.1. 
Uma análise foi realizada com as respostas dos 7 participantes do pré-teste e pelas características predominantes, uma instituição se enquadraria predominantemente no estágio Sucesso e outra no estágio Existência. Considerando especificamente cada uma das dimensões, sendo essas o processo de gestão e controle dos fluxos de caixa, sua utilização, e o seu estágio no ciclo de vida organizacional propriamente dito, cada uma das respostas às questões presentes no instrumento de coleta, apesar de algumas oscilações, representaram predominante as características dos estágios supracitados. A única exceção ocorreu em relação à dimensão utilização no caso de uma das instituições presentes no pré-teste, apontando um estágio mais rudimentar de utilização do instrumento, aparentemente incompatível com o seu estágio geral.

\subsubsection{Modelo de análise}

A regra julgamental que foi utilizada para enquadrar as respostas dadas ao questionário em cada um dos ciclos de vida, tanto no pré-teste como no decorrer do estudo, seguiu o embasamento teórico presente no quadro 1 - Estágios do Ciclo de Vida Organizacional e suas Características e no quadro 3 - Relação de Autores, Temáticas e Questões presentes no decorrer do estudo, como também no quadro Questões x Ciclos de Vida Organizacional presente no Apêndice 3, item A.3.2, que auxiliam a materializar o raciocínio depreendido para relacionar as questões à abordagem teórica do ciclo de vida organizacional e aos construtos depreendidos acerca do processo de gestão e controle dos fluxos de caixa.

No referido quadro do Apêndice 3 especificamente, buscou-se relacionar as características do processo de gestão e controle dos fluxos de caixa com as características de cada estágio no ciclo de vida organizacional, baseando-se nos conceitos expostos no quadro 1. Esse esforço contribuirá para analisar o enquadramento do processo ao estágio, sendo um norteador para análise desenvolvida sobre as respostas dadas ao questionário.

Com o objetivo de sintetizar o raciocínio e inferências depreendidas do construto delineado na seção 6 que fundamenta este estudo, o quadro abaixo, que também embasou a análise, apresenta as características predominantes de cada estágio e as respectivas características esperadas do processo de gestão e controle dos fluxos de caixa. 
Este quadro além de ser fundamentado no construto teórico, também está embasado nos quadros 1 - Estágios do Ciclo de Vida Organizacional e suas Características, 3 - Relação de Autores, Temáticas e Questões, e no quadro Questões x Ciclos de Vida Organizacional presente no Apêndice 3, item A.3.2, extraindo destes a essência teórica de forma a concentrar em uma única representação o modelo que foi utilizado tanto na construção do questionário como na análise das respostas dadas pelos participantes de modo a qualificar o processo de gestão e controle dos fluxos da caixa da instituição, seu estágio no ciclo de vida organizacional, e por fim possibilitar a análise da suposta relação entre as temáticas.

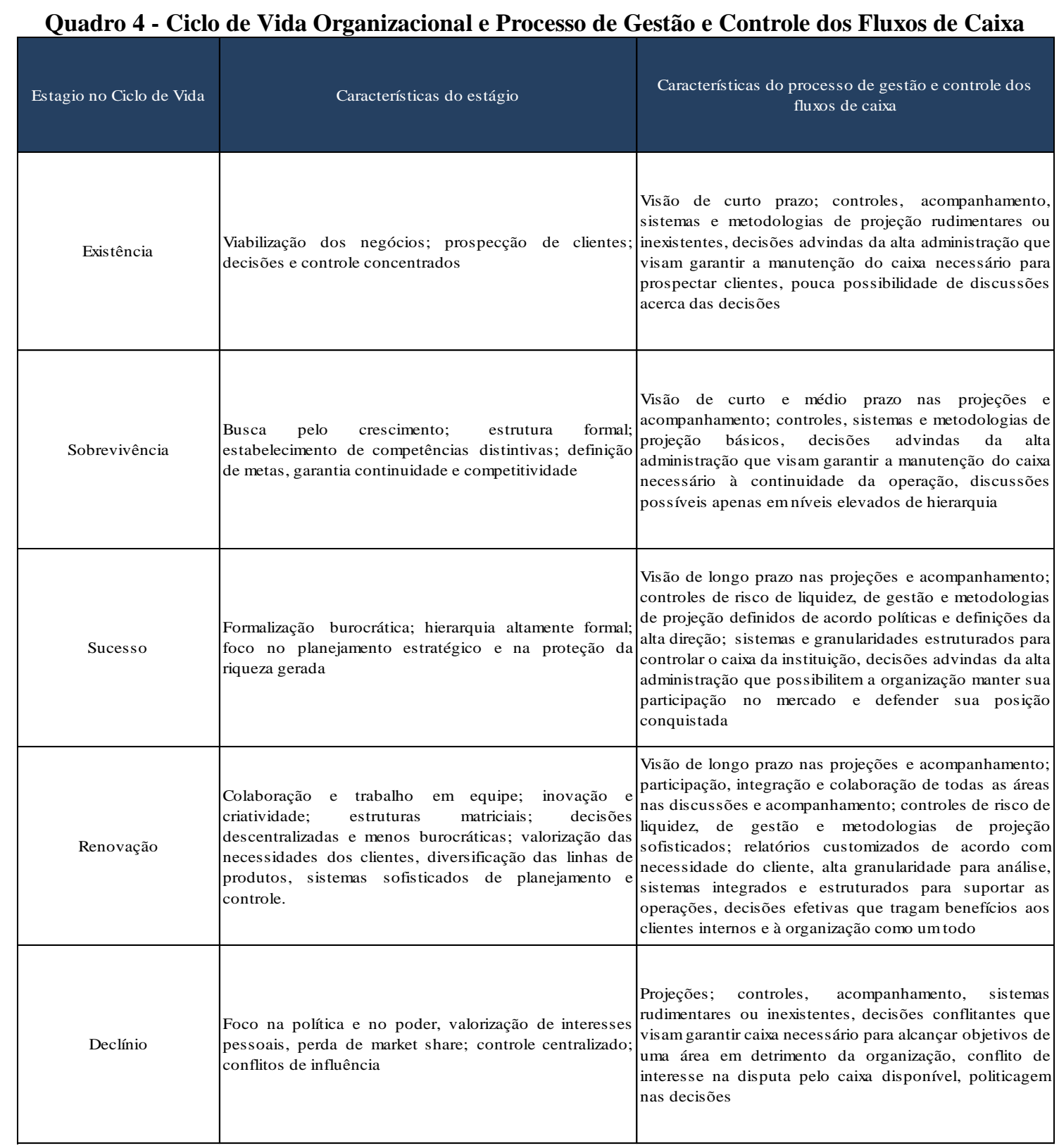

Fonte: Eaborado pelo autor com base em Soenen (1986), Lester, Parnnell e Carraher (1993); Frezatti (1997), Phillips (1997), Bessis (1998), Hempel e Simonson (1998), Kytönen (2004), Silvola (2008); Iturralde, Mas eda e San-Jose (2008, 2009), e Frezatti et al (2009) 
O modelo de análise, além de subsidiar a análise do pré-teste e do questionário de fato, também será utilizado como norteador nas entrevistas. A próxima subseção aborda a segunda etapa deste estudo de caso, caracterizada pelas entrevistas com os gestores gerais.

\subsection{Entrevista: delineamento e embasamento do roteiro}

A segunda etapa idealizada para este estudo de caso consiste de uma entrevista semiestruturada com os gestores imediatamente superiores àqueles participantes da primeira etapa. Segundo Martins e Theóphilo (2009), a entrevista é considerada uma técnica cujo objetivo básico é entender e compreender o significado atribuído pelos entrevistados a uma determinada temática de acordo com as suposições e conjecturas do pesquisador. Ainda segundo Martins e Theóphilo, uma entrevista pode oferecer elementos para corroborar evidências coletadas por outras fontes, possibilitando triangulações, sendo esta uma das necessidades para este estudo.

Segundo Bryman (2008), uma entrevista pode ser estruturada, não estruturada ou semiestruturada, sendo a primeira totalmente rígida, a segunda totalmente flexível e a última um estágio intermediário. Dada esta definição a entrevista semi-estruturada é o tipo mais adequado a este estudo. Esta escolha se deve ao fato de uma entrevista semiestruturada ser, dada sua flexibilidade, muito útil para captar as percepções acerca dos eventos analisados, dado que o entrevistado possui liberdade para expor e ressaltar pontos que entenda ser importantes para explicar os acontecimentos, os padrões e até mesmo as formas de comportamento (BRYMAN, 2008).

No entanto, ainda segundo Bryman (2008), para que o processo de entrevistar possa ser bem sucedido, o entrevistador deverá possuir certas habilidades, entre elas um sólido conhecimento acerca do assunto pesquisado; clareza nos questionamentos; flexibilidade para contornar eventuais ruídos presentes no ambiente; postura crítica para interagir e captar oportunidades durante a entrevista; gentileza e empatia com o entrevistado, construindo desse modo um elo produtivo durante a entrevista; entre outras características. 
Observadas as vantagens citadas, e atentando-se para as limitações indicadas de modo a dirimi-las, pretendeu-se por esse instrumento, especificamente, coletar a percepção dos gestores superiores de forma mais aprofundada, tendo por objetivo validar ou contrapor a percepção obtida com as respostas dos gestores e das equipes envolvidas com o processo de gestão e controle dos fluxos de caixa ao questionário disponibilizado na forma de formulário eletrônico, delineado na subseção 7.4.

A opção da entrevista semiestruturada se deu pelo fato da necessidade de captar eventuais percepções não presentes nas respostas do questionário, de ratificar pontos já expostos e reforçar, portanto, alguns aspectos importantes, e eventualmente contrapor alguma percepção advinda de primeira etapa. Esta etapa propicia triangulação das percepções de modo a tecer conclusões mais robustas acerca dos achados.

Para nortear a entrevista foi elaborado um roteiro para as entrevistas, constante no Apêndice 2. O roteiro possuiu a finalidade de levantar os pontos a serem explorados, atuando como direcionador das discussões, porém possibilitando aos entrevistados manifestarem-se acerca de aspectos não questionados e, ao entrevistador, complementar as discussões com questionamentos que não façam parte da pré-concepção de direcionamentos contidos no roteiro.

Para embasar teoricamente este roteiro norteador foram utilizados os mesmos quadros que embasaram o questionário, 1, 3, 4 e A.3.2, baseando-se nos conceitos contidos no referencial deste estudo, bem como nos construtos teóricos presentes na seção 6 , que se dispôs a delimitar as variáveis envolvidas na pesquisa, relacionando teoricamente as coletas de dados tanto via questionário como via entrevista, visto que, apesar de se tratar de formas diferentes de coletas e de públicos diferentes, ambas têm como finalidade investigar a mesma temática.

Foram ao todo três entrevistas individuais com os principais gestores gerais envolvidos no processo de gestão e controle dos fluxos de caixa na instituição pesquisada. As entrevistas foram realizadas logo após a coleta dos dados via questionário, sendo viabilizadas por agendamento prévio num intervalo de cerca de quinze dias de abrangência. Com a autorização dos respondentes, as entrevistas foram gravadas em arquivos eletrônicos de áudio, posteriormente transcritas em documentos digitais de texto e seu entendimento foi validado por cada um dos seus participantes. Os achados dessas duas etapas geraram informações 
preliminares, porém já robustas, subsidiando a terceira e última etapa que será descrita na próxima seção.

\subsection{Análise e triangulação}

Compilando as informações obtidas nas etapas um e dois, questionário e entrevista, e observando esses achados à luz da abordagem teórica presente em todo o trabalho, porém ressaltada nos construtos e quadros elucidativos, tornou-se possível tecer as conclusões gerais acerca do estudo, de modo a direcionar respostas para a questão pesquisada, atendendo aos objetivos do estudo, tanto o geral quanto os específicos. A triangulação entre questionário e entrevista permitiu identificar pontos conflitantes, confirmar achados importantes e evidenciar vários aspectos e percepções acerca do processo de gestão e controle dos fluxos de caixa e de sua relação com o estágio da instituição no ciclo de vida organizacional.

No entanto, como complemento da triangulação, entendeu-se necessário apresentar estas conclusões iniciais aos participantes da pesquisa de modo a confirmar as percepções e eventualmente complementar e ou ressaltar aspectos que mereçam tal tratamento. Esta etapa possuiu como finalidade produzir contornos finais à temática pesquisada, permitindo retratação e análise fidedignas e permitindo que a redação final dos achados refletisse da melhor forma possível os achados empíricos deste estudo de caso. Sendo assim, a próxima seção trará a redação dos achados, passando pelos aspectos de cada etapa e do delineamento final deste estudo, bem como das oportunidades de pesquisas futuras que advirão após esta primeira incursão sobre este recorte pioneiro acerca da temática da análise da prática da gestão e do controle dos fluxos de caixa em um banco brasileiro à luz da abordagem do ciclo de vida organizacional. 


\subsection{Participação do orçamento na gestão e controle dos fluxos de caixa}

Um dos objetivos específicos deste trabalho é identificar uma possível participação do orçamento no processo de gestão e controle dos fluxos de caixa. Para responder tal indagação uma das questões presente no instrumento de coleta foi inserida com este objetivo. As equipes que participam da estruturação e desenvolvimento do processo de gestão e controle dos fluxos de caixa na instituição analisada, tanto colaboradores quanto gestores, responderam a essa questão escolhendo, dentre as alternativas do tipo Likert 5, a que mais se adequava às suas percepções. A afirmação transcrita na questão buscava identificar se o processo de gestão e controle de fluxos de caixa da instituição possui alguma relação com as projeções orçamentárias de saldos, despesas e receitas, sendo estas atualizadas pela técnica do rolling forecast. A percepção das equipes é traduzida no gráfico abaixo

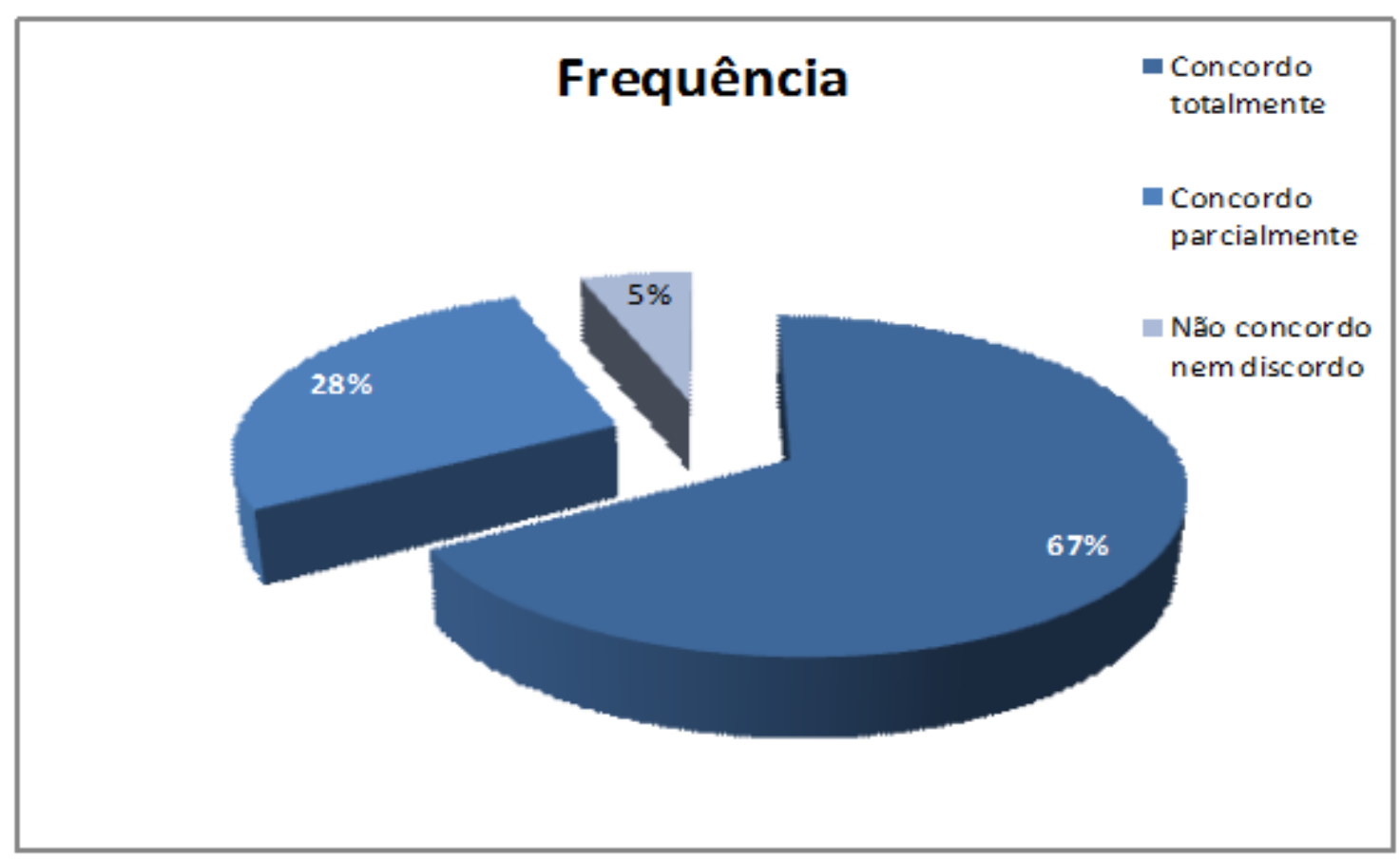

Gráfico 8 - Participação do orçamento 
Como ilustrado acima, as equipes reconhecem a participação do orçamento no processo de gestão e controle dos fluxos de caixa concordando totalmente $(67 \%)$ ou parcialmente $(28 \%)$ com a afirmação citada perfazendo uma concordância acumulada de 95\% em relação à participação do orçamento no controle e gestão do caixa na instituição em questão. Para contrapor e ou confirmar esta percepção advinda do questionário, buscou-se, nas entrevistas com os gestores gerais das áreas, afirmações acerca desta suposta participação do orçamento no processo de gestão e controle dos fluxos de caixa.

Dentre as percepções obtidas, está a de um dos gestores gerais entrevistados, que afirma que na instituição analisada o orçamento é de fato uma ferramenta utilizada na gestão, atrelando, portanto, o processo de gestão e controle dos fluxos de caixa ao acompanhamento de resultados e carteiras, sendo, deste modo, efetivo no mínimo para levantar questionamentos e suscitar críticas quanto a possíveis divergências de direcionamentos entre o orçamento e o processo de controle e gestão do caixa.

Entretanto, segundo este gestor, a comparação entre orçamento e gestão de caixa precisa ser flexível, já que podem ocorrer mudanças de micro estratégias nas áreas sem necessariamente alterarem o todo, desta forma não é correto vincular integralmente as projeções orçamentárias à gestão do caixa. Ainda segundo este gestor geral, a ligação entre as duas temáticas também pode, de alguma forma, influenciar indiretamente a construção de metas e a avaliação de desempenho, pois o fato de o orçamento ter como uma de suas componentes a projeção de fluxos de caixa faz com que as áreas somente consigam projetar corretamente seu desempenho se levarem em consideração o caixa disponível e os limites de consumo e de geração de caixa estabelecidos de acordo com as políticas internas.

Outro gestor geral confirma as percepções dos colaboradores e do primeiro gestor geral, afirmando que a integração entre estes dois artefatos é fundamental, mesmo que existam limitações, visto que, pela natureza dinâmica do processo de gestão e controle do caixa, as projeções de fluxos de caixa tendem a se distanciar do orçamento de carteiras e resultados com o passar dos dias, pois tradicionalmente, quando não atualizado, o orçamento torna-se uma peça estática. Este gestor também afirma que a figura do rolling forecast que mitiga a característica estática do orçamento tradicional tem contribuído para integrar e unificar o orçamento e o controle de liquidez. 
Todavia, na percepção deste gestor, não se pode afirmar unicamente que apenas o orçamento contribua e subsidie o processo de gestão e controle de caixa, pois o processo de gestão e controle dos fluxos de caixa também é importante para direcionar o orçamento, visto que a liquidez da instituição interfere em seu resultado global, criando a necessidade de alinhamentos e discussões advindas da interação entre os dois artefatos de forma a se alcançar resultados ótimos.

A percepção do terceiro gestor geral corrobora com a última sentença do gestor anterior, que ressalta a influência da gestão no caixa no orçamento, quando afirma que num futuro próximo, em função da inclusão do novo arcabouço advindo do terceiro acordo de Basileia, a forma como o orçamento do banco é realizado será transformada. Segundo este gestor, a instituição terá que acompanhar um indicador de longo prazo denominado Net Stable Funding Ratio (NSFR) que envolverá na íntegra o balanço do banco, orientando a necessidade de manutenção de uma estrutura de funding adequada para cada conta do balanço, definindo o percentual de funding exigido para as operações presentes no ativo e o montante de funding disponível de acordo com as características do cliente e com o prazo das operações existentes no passivo. Esta decisão obrigará o processo orçamentário a considerar uma estrutura mínima exigida balizando o orçamento das áreas de negócios.

Do mesmo modo, outro indicador denominado Liquidity Coverage Ratio (LCR), que é um indicador de curto prazo, irá exigir uma coordenação entre as áreas para que possa ser mantido e, segundo opinião deste gestor, não haverá melhor ferramenta que o orçamento para promover esta integração. A percepção deste gestor é que as discussões acerca destas métricas deverão fazer parte da rotina das áreas, do processo orçamentário e do processo de gestão e controle dos fluxos de caixa. Esta afirmação também corrobora a influência das medidas regulatórias no processo de gestão e controle dos fluxos de caixa.

Com base nas percepções acima apresentadas é possível depreender especificamente que, em relação ao caso estudado, o orçamento está fortemente relacionado ao processo de gestão e controle dos fluxos de caixa, tendo o importante papel de suscitar discussões e reflexões, e de integrar o acompanhamento dos indicadores financeiros do banco, possivelmente vinculando avaliação de desempenho, projeção de lucros futuros, projeção de carteiras e market share, 
controle regulatório e projeção de caixa. Esta constatação vai ao encontro dos estudos de Phillips (1997), Kytönen (2004) e Iturralde, Maseda e San-Jose (2009) que também evidenciaram em seus estudos a importante participação do orçamento na seara do controle e gestão do caixa.

No caso da instituição financeira em análise, percebe-se que a principal limitação de integração entre orçamento e caixa, que é a natureza estática do orçamento, vem sendo superada pela utilização da técnica denominada rolling forecast, que atualiza periodicamente as projeções orçamentárias, tornando-as mais dinâmicas e mais integradas com a gestão e controle do caixa, permitindo unicidade de informações para os dois processos e um efeito ótimo para a instituição, sendo este somente possível pela gestão integrada destas duas ferramentas. Este achado também corrobora com o estudo de Soenen (1986) que relatou a utilização do orçamento retificado por rolling forecasts como técnica presente no processo de gestão e controle dos fluxos de caixa.

Deste modo, a resposta ao quarto objetivo específico deste estudo de caso é a confirmação da participação do orçamento no processo de gestão e controle dos fluxos de caixa, demonstrando que, assim como em instituições não financeiras, também em uma instituição financeira, esta importante ferramenta possui papel de destaque na gestão e controle dos fluxos de caixa.

\subsection{Convergência e ou Divergência de percepções acerca do processo de gestão e controle dos fluxos de caixa}

Para conferir maior robustez e confiabilidade aos achados, é importante verificar se as percepções acerca do ciclo de vida organizacional e do processo de gestão e controle dos fluxos de caixa são convergentes ou divergentes entre as áreas que conduzem o processo de gestão e controle dos fluxos de caixa. Para tanto, a Seção A do questionário buscou caracterizar o respondente, principalmente pela área da qual faz parte, mas também pelo sexo, pelo tempo em que o respondente está na instituição, no entanto as duas últimas características, sexo e tempo na empresa, acabaram por ser apenas ilustrativas para efeito da análise realizada. 
Esta caracterização irá colaborar para a realização de comparações entre as percepções das áreas, verificando se há divergência quanto a alguma das variáveis representativas do construto analisado por meio do instrumento de coleta, e contrapor também estas percepções à respectiva percepção do gestor geral de cada área, perfazendo a percepção representativa de cada área. Os dois gráficos seguintes apresentam a caracterização geral dos respondentes do questionário.

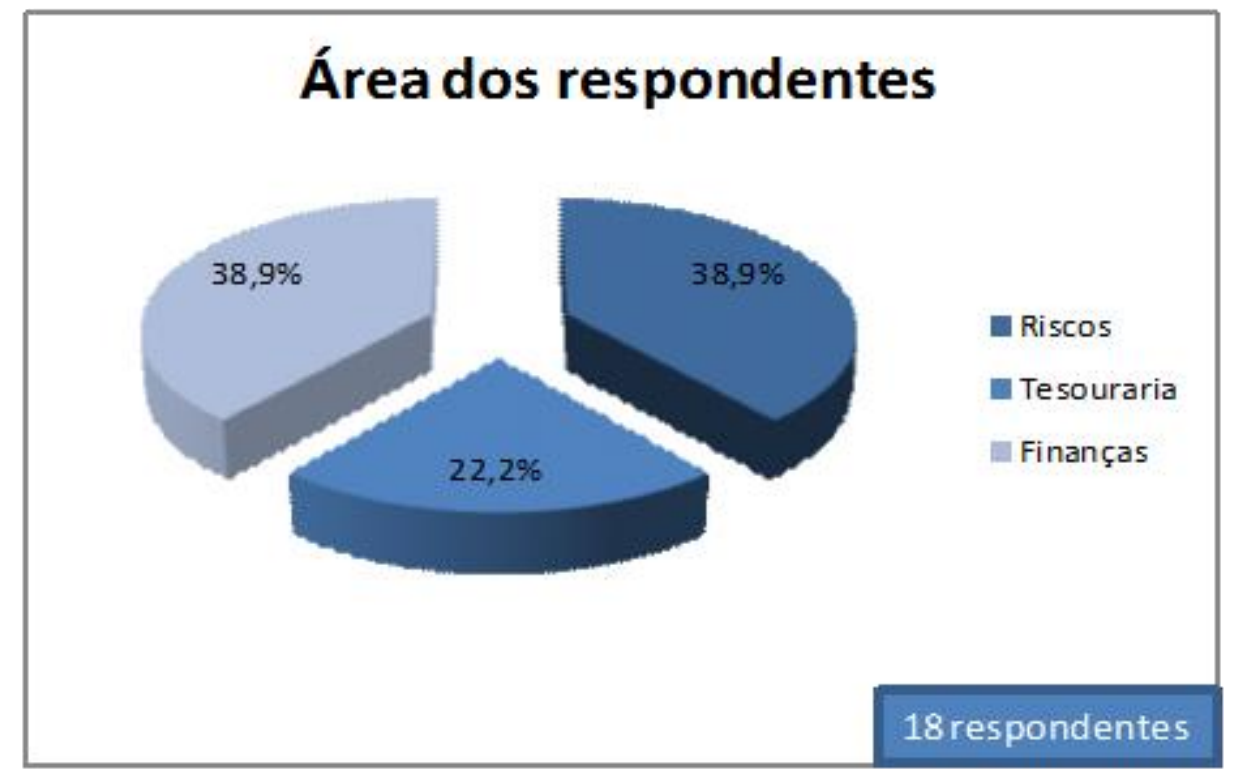

Gráfico 9 - Área

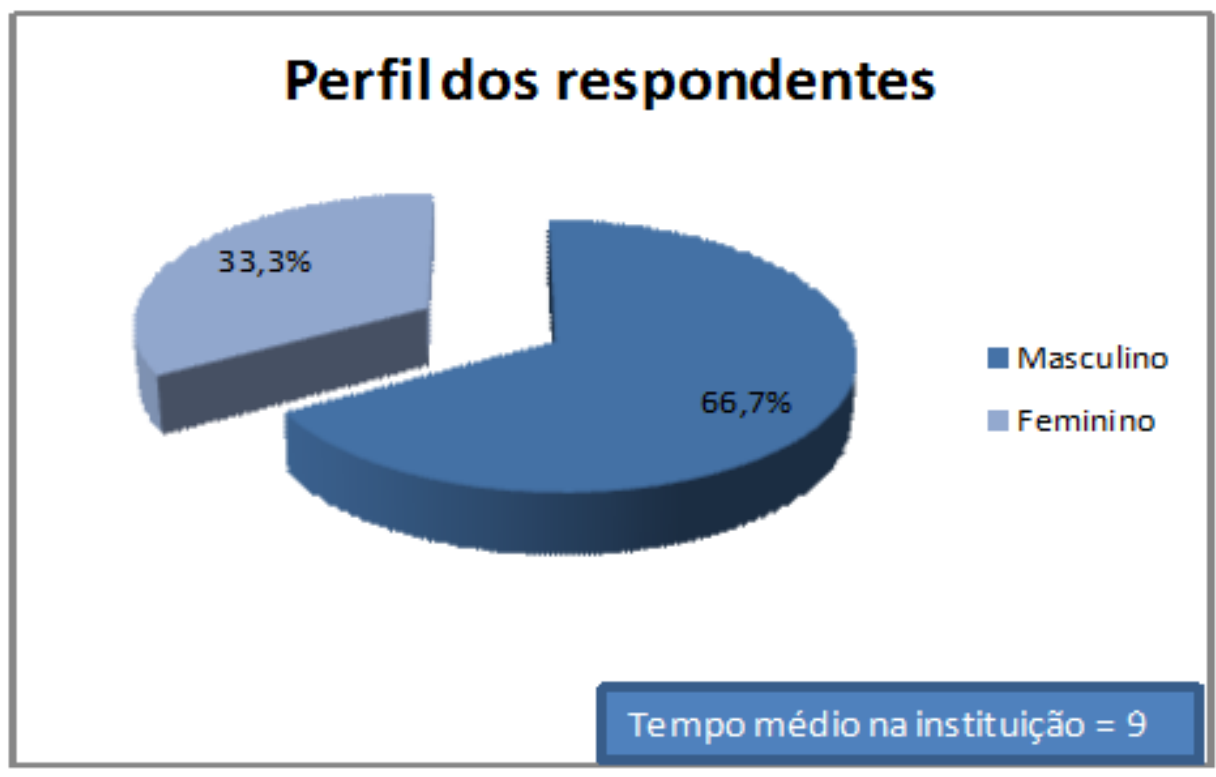

Gráfico 10 - Perfil 
Como demonstrado acima, 18 foram os colaboradores e gestores que responderam ao questionário, estando estes bem distribuídos entre as três áreas responsáveis pelo processo de gestão e controle dos fluxos de caixa, com predominância dos profissionais das áreas de riscos e finanças. Também se observa a predominância de respondentes do sexo masculino.

Considerando todas as respostas dos participantes, com base no quadro presente no Apêndice 3 (item A.3.2) que relaciona os estágios no ciclo de vida às questões do instrumento de coleta, torna-se possível classificar a instituição em análise em cada uma das variáveis do construto norteador deste estudo. Este relacionamento é possível, pois cada bloco do questionário está relacionado à teoria entretecida no construto que permeia este estudo. Desta forma, considerando as respostas com maior frequência para definir a classificação, se pode observar a seguinte configuração:

- A variável representativa do Modelo de Gestão foi classificada no estágio de Renovação,

- A variável representativa dos Elementos Informacionais, Técnicos e Tecnológicos foi classificada no estágio de Sucesso,

- A variável representativa da Utilização foi classificada no estágio de Renovação,

- E a variável representativa do Ciclo de Vida Organizacional baseada no modelo de Lester, Parnell e Carraher (1993) foi classificada entre os estágios de Sucesso e Renovação.

Analisando em detalhes cada uma das variáveis é possível constatar que a percepção dominante da variável Modelo de Gestão é condizente com estágio no ciclo de vida organizacional denominado Renovação e apresenta frequência superior a 65\%, assim como a percepção dominante da variável Utilização é condizente com estágio no ciclo de vida organizacional denominado Renovação, porém com frequência superior a 55\%. O ciclo de vida organizacional da instituição dividiu as percepções entre os estágios de Sucesso e Renovação superando a frequência de $44 \%$ para cada um dos estágios.

Também se pode observar que uma única variável dividiu bastante as opiniões, aquela representativa dos Elementos Informacionais, Técnicos e Tecnológicos, cuja percepção dominante é condizente com o estágio de Sucesso, porém com frequência predominante de 
$33 \%$. A percepção dos questionários é ratificada pela percepção coletada nas entrevistas com os gestores gerais, que também citam muitas características que levam ao enquadramento da instituição entre os ciclos de vida de Renovação e Sucesso e dos seus processos de gestão e controle dos fluxos de caixa também entre estes dois estágios.

Destacam-se, entre as afirmações dos gestores gerais, o reconhecimento da grandeza da instituição e da sua importância no mercado; da sua busca pela melhoria contínua do seu processo de gestão e controle dos fluxos de caixa; do investimento em tecnologia com o intuito de acompanhar as demandas dinâmicas e o crescimento da instituição; do envolvimento e colaboração das áreas na gestão do caixa em função do modelo de gestão, das políticas e do modelo de avaliação de desempenho; e das constantes reavaliações das limitações e pontos de melhoria observados, com o objetivo de construir planos de ação para tornar o processo de gestão e controle dos fluxos caixa condizente com a magnitude da instituição.

Assim como os colaboradores, os Elementos Informacionais, Tecnológicos e Técnicos são os que, na percepção dos gestores gerais, possuem mais pontos de melhorias, porém muitos destes já com planos de ação em andamento. Outro ponto ressaltado como obstáculo a ser superado reside no grande tamanho da instituição que torna muitos aspectos mais complicados, requerendo maior atenção para possibilitarem sua otimização.

Deste modo, por se tratar de uma grande instituição e em função de o seu tamanho tornar alguns aspectos mais complicados, seria possível que as percepções obtidas acima possam ser muito distintas entre as áreas analisadas. Percepções muito díspares poderiam dificultar a análise do todo, visto que a percepção dos colaboradores embasará os achados e espera-se que as percepções coletadas, tanto nas respostas aos questionários como nas entrevistas, sejam representativas da posição da instituição quanto ao seu estágio no ciclo de vida organizacional, quanto ao seu processo de gestão e controle dos fluxos de caixa e quanto a eventual relação entre estas duas temáticas. Para tanto, com o objetivo de verificar se a estrutura de percepções supracitadas também é refletida quando se decompõem as áreas, a mesma análise feita na visão consolidada, foi realizada para cada uma das áreas. 
Deste modo, com o objetivo de verificar a convergência ou divergência entre as áreas, iniciou-se a análise pela área de Finanças que possui mais mulheres e um ano a menos em média de tempo na instituição que a média visão consolidada. Estas afirmações podem ser visualizadas no gráfico seguinte.

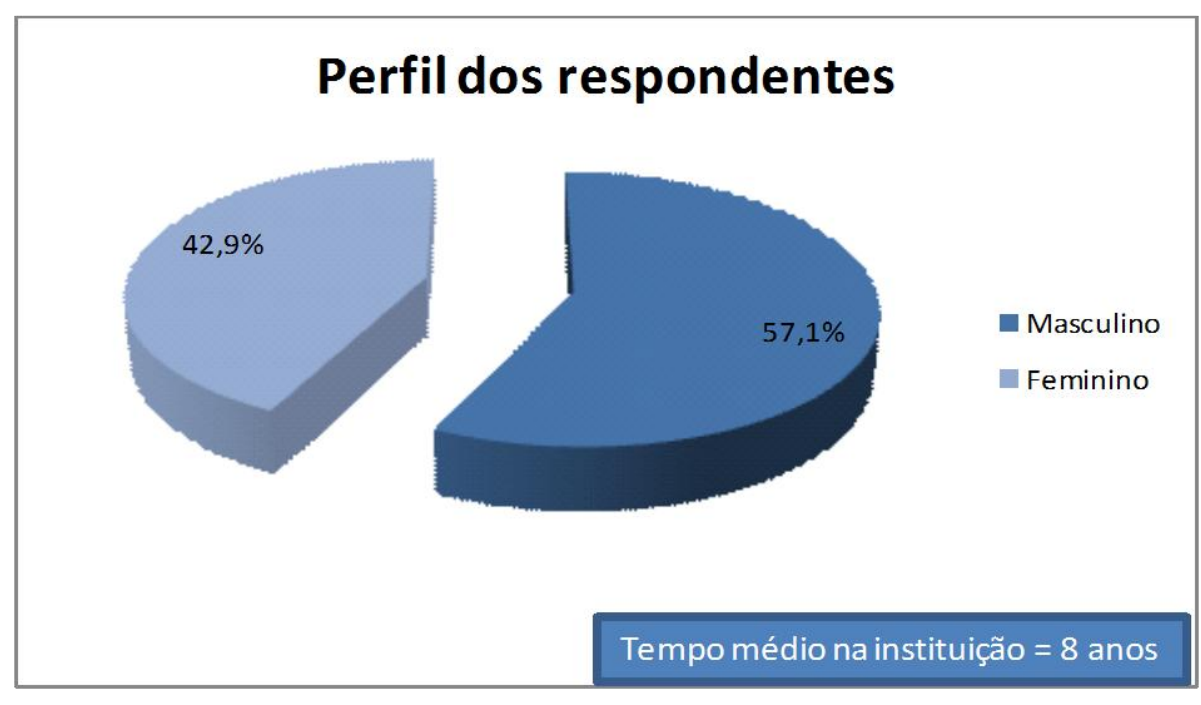

Gráfico 11 - Perfil de Finanças

Quanto às percepções da área acerca das variáveis, tem-se a seguinte configuração:

- A variável representativa do Modelo de Gestão foi classificada no estágio de Renovação,

- A variável representativa dos Elementos Informacionais, Técnicos e Tecnológicos foi classificada no estágio de Sucesso,

- A variável representativa da Utilização foi classificada no estágio de Renovação,

- E a variável representativa do Ciclo de Vida Organizacional baseada no modelo de Lester, Parnell e Carraher (1993) foi classificada no estágio de Sucesso.

Em linhas gerais, a percepção da área de Finanças é idêntica à percepção consolidada, com exceção ao ciclo de vida organizacional da instituição que não dividiu as percepções, como na visão consolidada, ficando enquadrado somente no estágio de Sucesso com frequência dominante superior a $70 \%$. Entretanto, adentrando os meandros de cada variável, é possível encontrar diferentes frequências quanto às percepções dominantes, como no caso da variável Modelo de Gestão e Utilização, que são condizentes com estágio no ciclo de vida 
organizacional denominado Renovação, com frequência superior a $71 \%$ e a $57 \%$ respectivamente, e da variável representativa dos Elementos Informacionais, Técnicos e Tecnológicos, cuja percepção dominante é condizente com o estágio denominado Sucesso, com frequência predominante de $57 \%$, sendo esta bem superior à frequência predominante da visão consolidada.

A percepção geral advinda da entrevista com o gestor geral confirma a percepção do questionário e enquadra tanto o ciclo de vida organizacional como o processo de gestão e controle dos fluxos de caixa entre os estágios de Sucesso e Renovação, sendo importante ressaltar que parte das divergências entre a percepção consolidada e a percepção de Finanças pode ser explicada pelas percepções coletadas na entrevista. Entre os pontos a ressaltar está a maior representatividade da frequência predominante para a variável representativa dos Elementos Informacionais, Técnicos e Tecnológicos quando comparada à percepção consolidada, podendo este fato ser explicado pela afirmação do gestor geral que percebe timing, granularidade e customização adequados à relação custo-benefício destes itens, porém por certo não enquadraria a variável no estágio de Renovação por observar pontos de melhoria para a variável como o esclarecimento e unificação de nomenclaturas da granularidade atual, e o aprimoramento da integridade das fontes de informação.

O estágio global da instituição que, na visão consolidada, está enquadrado entre Sucesso e Renovação, e na visão de Finanças é enquadrado no estágio de Sucesso, também pode ser explicado em parte pela percepção declarada pelo gestor geral de que o desempenho global poderia ser ainda melhor do que o atual, bem como pelo fato da necessidade de maior envolvimento do planejamento financeiro das áreas de negócios para tornar o processo ainda mais rico e dinâmico. Por certo estas características citadas pelo gestor geral estão incutidas nas discussões rotineiras da área sendo determinantes na percepção dos colaboradores e gestores de finanças para enquadrar a instituição unicamente no estágio de Sucesso.

A segunda área analisada é a área de riscos cujo perfil é demonstrado no gráfico a seguir com menos mulheres que a média da visão consolidada, porém com tempo médio na instituição bem superior à média da visão consolidada. 


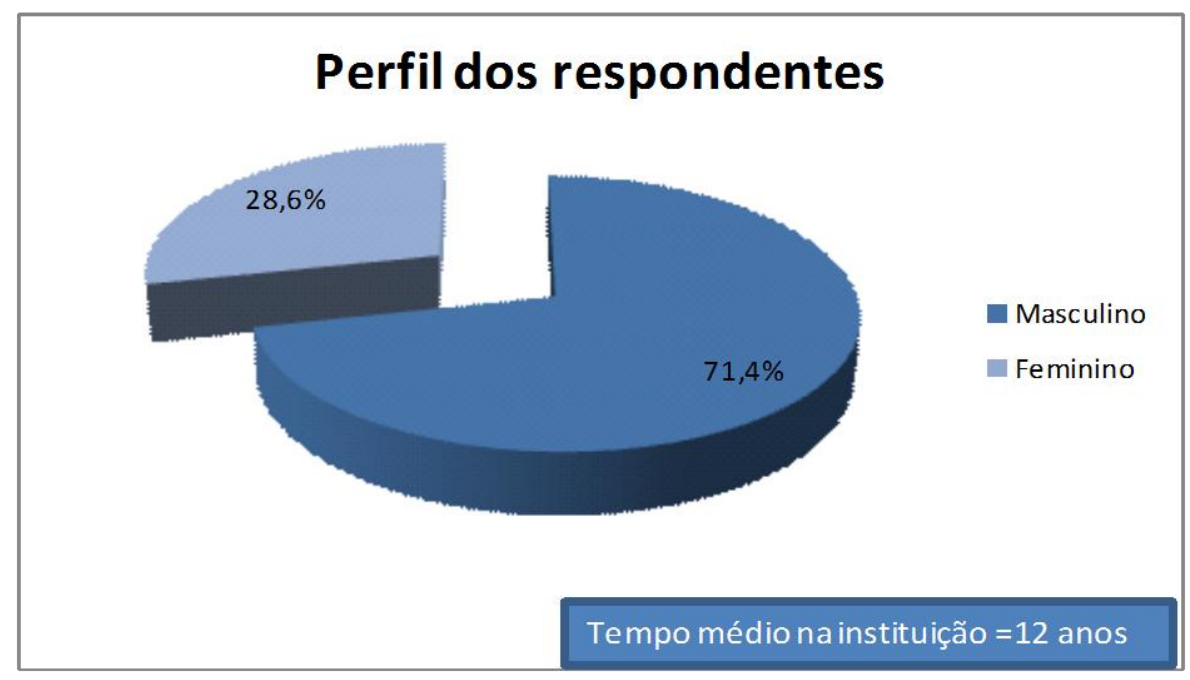

Gráfico 12 - Perfil de Riscos

Quanto às percepções da área acerca das variáveis, tem-se a seguinte configuração:

- A variável representativa do Modelo de Gestão foi classificada no estágio de Renovação,

- A variável representativa dos Elementos Informacionais, Técnicos e Tecnológicos foi classificada no estágio de Renovação,

- A variável representativa da Utilização foi classificada no estágio de Renovação,

- E a variável representativa do Ciclo de Vida Organizacional baseada no modelo de Lester, Parnell e Carraher (1993) foi classificada no estágio de Renovação.

Em linhas gerais, a percepção da área de Riscos é melhor que a percepção consolidada. Analisando os detalhes de cada variável é possível evidenciar as frequências quanto às percepções dominantes, sendo todas condizentes com o estágio no ciclo de vida organizacional denominado Renovação com frequência superior a $71 \%$ para as variáveis representativas do Modelo de Gestão e Utilização, e superior a 57\% para as variáveis representativas dos Elementos Informacionais, Técnicos e Tecnológicos e Ciclo de Vida Organizacional.

Já em relação às percepções obtidas na entrevista com o gestor geral, pode-se afirmar que estas se mostraram mais críticas que as percepções obtidas pelos questionários. Entre as oportunidades de melhoria apontadas estão limitações nos sistemas de informação; e a existência de um modelo um pouco centralizado e burocrático para definição de políticas, 
controles e tomada de decisão em caixa, porém necessário na opinião deste gestor em função do grande tamanho da instituição. Outro ponto, que já havia sido apontado por outro gestor geral e que tornou a ser citado por este gestor, é a percepção de que o desempenho e eficiência da instituição poderiam possuir níveis ainda melhores que os atuais.

Em contraponto às melhorias necessárias, a instituição se destaca pelo pioneirismo no cumprimento das medidas regulatórias e por ser um benchmarking nacional em filosofia de gestão do caixa. Dadas às oportunidades de melhoria e características apontadas, o ciclo de vida organizacional e o processo de gestão e controle dos fluxos de caixa se enquadrariam entre os estágios de Sucesso e Sobrevivência, diferentemente do estágio depreendido pela percepção captada pelo questionário, levando à inferência de divergência de percepção dentro da área, porém a visão da área, composta pelas respostas ao questionário e à entrevista, ainda é representativa e bem próxima à visão consolidada.

A última área a ser analisada é a Tesouraria que possui o menor tempo médio na instituição, apenas 5 anos, quando comparada com as outras áreas pesquisadas, e menos mulheres proporcionalmente, apenas $25 \%$ entre os respondentes, também quando comparada com as outras áreas e consequentemente com a média geral. A análise das variáveis demonstrou os seguintes achados:

- A variável representativa do Modelo de Gestão foi classificada no estágio de Renovação,

- A variável representativa dos Elementos Informacionais, Técnicos e Tecnológicos foi classificada no estágio de Sucesso,

- A variável representativa da Utilização foi classificada Inconclusiva,

- E a variável representativa do Ciclo de Vida Organizacional baseada no modelo de Lester, Parnell e Carraher, (1993) foi classificada no estágio de Renovação.

O gráfico a seguir representa o perfil da área com a sua composição percentual e com a ilustração do tempo médio na instituição. 


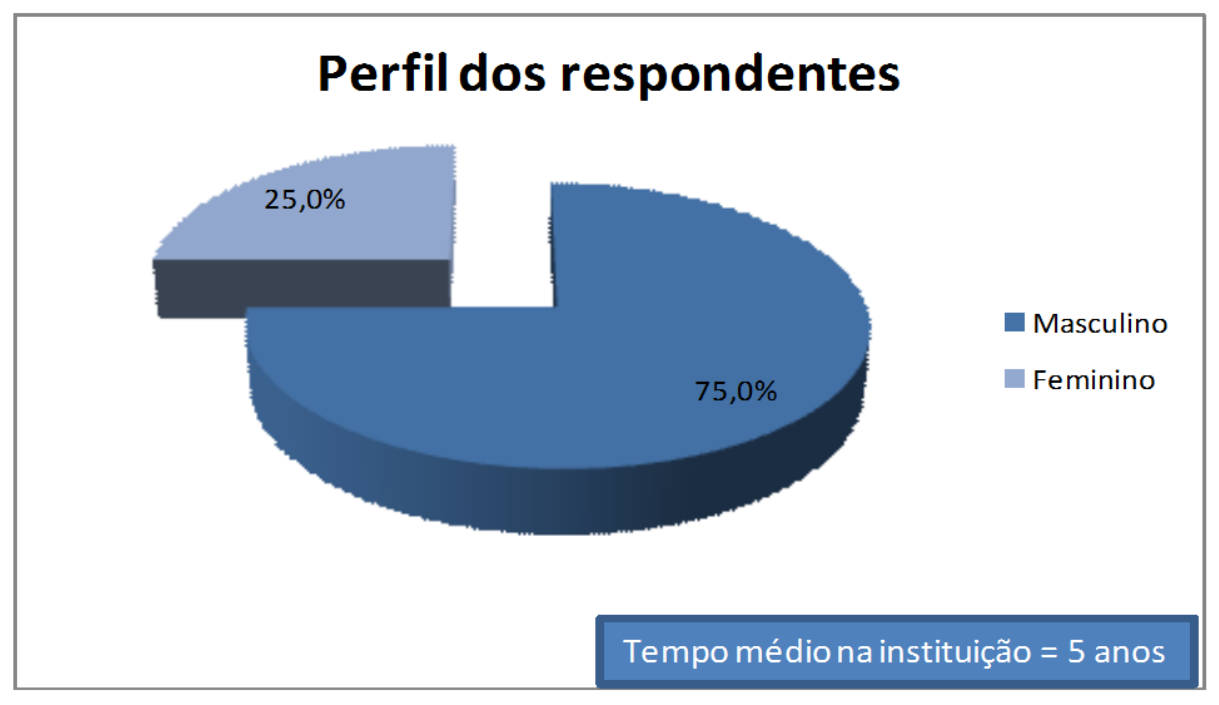

Gráfico 13 - Perfil Tesouraria

Quando comparada com a visão consolidada, a percepção da área de Tesouraria se demonstrou bem aderente. Pela abertura dos detalhes de cada variável é possível evidenciar a percepção dominante da variável que representa o Modelo de Gestão, sendo esta condizente com o estágio no ciclo de vida organizacional denominado Renovação, apresentando frequência de 50\%; assim como a percepção dominante da variável que representa os Elementos Informacionais, Técnicos e Tecnológicos é condizente com o estágio no ciclo de vida organizacional denominado Sucesso, porém com frequência de 50\%; e a percepção dominante e o estágio no ciclo de vida organizacional no qual a instituição se enquadra é o estágio denominado Renovação com frequência de 75\%. A variável Utilização demonstrou-se inconclusiva em função de dividir as percepções.

A percepção do gestor geral da Tesouraria foi bastante positiva e similar à percepção do gestor geral da área de Finanças, destacando pontos positivos como: o envolvimento das áreas no processo, a grandeza e importância da instituição, o desempenho diferenciado e a busca constante pelas melhores práticas e por melhorias nos processos e controles, por possuir um modelo ótimo de gestão e por possuir desempenho e eficiência destacados no mercado em que está inserida. Os principais pontos de melhoria na percepção do gestor geral, sendo todos eles encaminhados por planos de ação, são decorrentes de lacunas informacionais, bem como das dificuldades advindas da magnitude da instituição que acaba por tornar certos processos bastante complexos. 
Estas percepções enquadrariam tanto o ciclo de vida organizacional como o processo de gestão e controle dos fluxos de caixa da instituição entre os estágios de Renovação e Sucesso. A aparente dúvida existente quanto à variável Utilização não existe na percepção do gestor geral dado que, em função da formatação do modelo de gestão, as decisões e controles advindos do processo de gestão e controle dos fluxos de caixa acabam sendo utilizadas efetivamente pelas diversas áreas. A tabela 1 resume os achados.

Tabela 1 - Percepções Questionário

\begin{tabular}{ccccc}
\cline { 2 - 4 } & \multicolumn{2}{c}{ Percepção } & \\
\hline Variáveis & Consol. & Finanças & Tesouraria & Riscos \\
\hline $\begin{array}{c}\text { Modelo de Gestão } \\
\text { Elementos Técnicos } \\
\text { Tecnológicos e } \\
\text { Informacionais }\end{array}$ & Renovação & Renovação & Renovação & Renovação \\
\hline $\begin{array}{c}\text { Utilização } \\
\text { Ciclo de Vida }\end{array}$ & Renovação & Renovação & Inconclusivo & Renovação \\
Organizacional & Sucesso & Sucesso & Renovação \\
\hline
\end{tabular}

Sendo assim, não se verifica grandes divergências de percepção entre as diversas áreas e a visão consolidada da instituição quanto ao estágio no ciclo de vida organizacional no qual a instituição está inserida, e quanto ao estágio no ciclo de vida organizacional que eventualmente seria condizente com o atual processo de gestão e controle dos fluxos de caixa na instituição. Esta aparente convergência de percepções é bastante positiva, visto que, pela magnitude da instituição, a existência de uma percepção uniforme não seria tão esperada. As divergências mais relevantes, porém não tão significantes quando se observa o todo, foram evidenciadas pela divergência entre a percepção mais tática dos colaboradores e gestores em comparação à percepção mais estratégica do gestor geral, dentro das próprias áreas.

Por esta constatação, de modo a conferir maior confiabilidade aos achados, pela verificação da convergência e ou divergência de percepções entre as três áreas que participam diretamente do processo de gestão e controle dos fluxos de caixa, pode-se afirmar que, em linhas gerais, as 
percepções são muito parecidas e que a percepção de cada área é muito aderente à percepção do todo.

Este achado é de grande valia, pois trará maior robustez à resposta dada ao objetivo principal do estudo, bem como à questão de pesquisa proposta, dado que a conjunção das percepções das partes representará a percepção da instituição, sendo esta uma forma de triangulação dos dados, passo este recomendado por Yin (2010) para conferir confiabilidade ao estudo de caso.

\subsection{Relacionamento entre o estágio no ciclo de vida organizacional e o processo de gestão e controle dos fluxos de caixa}

\subsubsection{Formatação e direcionamento da análise}

Nas duas seções anteriores, foram analisados e evidenciados aspectos secundários deste estudo: a participação do orçamento na gestão e controle dos fluxos de caixa, e a convergência de percepções entre as diversas áreas que participam deste processo. Esta seção tem por finalidade analisar e evidenciar o objetivo central e responder, de alguma forma, a questão de pesquisa proposta.

Para tanto, por meio da percepção coletada nos questionários foram construídas variáveis que embasaram as análises, tanto da classificação da instituição em um dos estágios do ciclo de vida organizacional, como da análise da relação entre este e o processo de gestão e controle dos fluxos de caixa. Tratando-se do processo de gestão e controle dos fluxos de caixa, as variáveis analisadas são as mesmas que integraram a análise da seção anterior, sendo elas o Modelo de Gestão, os Elementos Informacionais, Tecnológicos e Técnicos e a Utilização. Quando agrupadas, as três variáveis serão consideradas como representativas de uma variável única denominada Processo de Gestão e Controle dos Fluxos de Caixa. A esta análise se acrescentou a percepção dos gestores gerais, coletada por meio das entrevistas para complementar, explicar e contrapor os resultados obtidos.

Da mesma forma, dado um conjunto de questões, desejou-se verificar a adequação do modelo de classificação das empresas nos estágios do ciclo de vida organizacional a um banco, visto que, tanto em sua forma original por meio do modelo desenvolvido por Miller e Friesen 
(1983, 1984) como na evolução construída por Lester, Parnell e Carraher (1993) que embasa este estudo, esta abordagem sempre foi aplicada e testada em empresas não financeiras. Sendo assim, embasado nos estágios descritos, bem como nas questões desenvolvidas por Lester, Parnell e Carraher (1993) se objetivou classificar a instituição financeira analisada neste estudo de caso em um dos estágios do ciclo de vida organizacional, atendendo ao primeiro objetivo específico, sendo estes estágios: Existência, Sobrevivência, Sucesso, Renovação ou Declínio. A variável que possui esta finalidade é denominada Ciclo de Vida Organizacional. Ao exame desta percepção realizado pela análise das respostas dadas às questões também se acrescentaram as percepções coletadas nas entrevistas com os gestores gerais que contribuíram com a análise.

Deste modo, parte do objetivo principal, bem como o primeiro objetivo específico deste estudo foi suprida pela verificação da possibilidade de enquadramento de um banco no modelo desenvolvido por Lester, Parnell e Carraher (1993) que representa a abordagem teórica do ciclo de vida organizacional. Dada esta fase inicial de identificação do estágio da instituição no ciclo de vida organizacional também se empreendeu esforço na construção e formatação das variáveis referentes aos fluxos de caixa. Estas variáveis foram contrapostas ao estágio no ciclo de vida organizacional percebido pelos respondentes, codificado em uma variável, objetivando verificar se há ou não relação entre as duas métricas, dado que esta finalidade complementa o objetivo principal deste estudo.

Para formar as variáveis, as respostas dadas às questões que definem o estágio da instituição no ciclo de vida organizacional foram tratadas com o intuito de se obter o estágio percebido para cada um dos respondentes. As questões do instrumento de coleta que captam esta percepção estão na Seção E do Apêndice 1, compreendendo as questões 23 a 31. Para definir o estágio foi utilizado o quadro presente no Apêndice 3 (item A.3.2), verificando, para cada respondente, o estágio com maior frequência dentre as respostas dadas às questões, determinando, desta forma, o estágio dominante para cada observação, dando origem à variável denominada Ciclo de Vida Organizacional.

Já para formar as variáveis referentes ao processo de gestão e controle dos fluxos de caixa, foram utilizadas as respostas dadas às questões relativas ao processo de gestão e controle dos fluxos de caixa, presentes no questionário desde a Seção A até a Seção D do Apêndice 1, 
sendo as alternativas de respostas a estas questões em sua maioria Likert-5, exceto para as questões 17, 18 e 19. Entretanto, foi realizada a padronização das variáveis com intuito de mensurar a percepção dominante para cada uma delas em termos de escala Likert-5, incluindo as três questões de múltipla escolha.

Em seguida, foi realizado o agrupamento das questões representativas de cada uma das variáveis, seguindo esta sequência: a variável denominada Modelo de Gestão que é formada pelas questões 4 a 9; a variável denominada Elementos Informacionais, Tecnológicos e Técnicos que é formada pelas questões 10 a 18, com exceção da questão 16; e a variável denominada Utilização que é formada pelas questões 19 a 22. Para cada grupo de questões que define cada uma das três variáveis, foi considerada a alternativa Likert-5 com maior frequência para cada observação, definindo, portanto, a alternativa dominante. Em caso de empate com relação às frequências foram eleitas algumas questões dominantes para cada uma das três variáveis, de modo a possibilitar que estas questões possuíssem maior peso para um eventual desempate entre alternativas dominantes.

Para a variável Modelo de Gestão foi definida a questão 4 como dominante, para a variável Elementos Informacionais, Tecnológicos e Técnicos foi escolhida a questão 15 como dominante e, para a variável Utilização, foi escolhida a questão 21 como dominante. Estas escolhas foram embasadas na análise das percepções obtidas nas entrevistas realizadas com os gestores gerais de cada uma das três áreas participantes de acordo com o enfoque dado às temáticas abordadas. Por fim, também foi construída uma variável representativa do todo, agrupando as outras três vaiáveis em uma única variável denominada Processo de Gestão e Controle dos Fluxos de Caixa, conforme afirmado anteriormente.

Para tanto, com o intuito de analisar a relação entre as variáveis, serão utilizadas duas técnicas estatísticas: a técnica estatística denominada Análise de Correspondência (ANACOR) que, segundo Fávero et al. (2009), é uma técnica que exibe as associações entre um conjunto de variáveis categóricas não métricas em um mapa perceptual, destinado ao estudo da relação entre duas variáveis qualitativas; e a técnica estatística denominada Análise de Homogeneidade (HOMALS) que, conforme Fávero et al. (2009), é uma técnica de análise de homogeneidade utilizada para o estudo das relações entre duas ou mais variáveis nominais ou 
ordinais, permitindo analisar a relação entre todas as variáveis, de forma conjunta e simultânea, a partir de uma configuração simples e bidimensional.

Partindo da base de dados construída de acordo com as regras supracitadas e utilizando as técnicas estatísticas denominadas ANACOR e HOMALS, buscou-se analisar cada uma das variáveis em relação ao estágio do ciclo de vida organizacional. Inicialmente foi analisada cada variável referente ao caixa em relação à variável do ciclo de vida organizacional. Sendo assim, foram analisadas a relação das seguintes variáveis com a variável Ciclo de Vida Organizacional: Modelo de Gestão, Elementos Informacionais, Tecnológicos e Técnicos, Utilização e a variável síntese denominada Processo de Gestão e Controle dos Fluxos de Caixa. Esta análise foi realizada pela aplicação da técnica estatística denominada ANACOR.

Em complemento a esta análise, foi realizada uma análise complementar, considerando simultaneamente as três variáveis que compõem o processo de gestão e controle dos fluxos de caixa e o estágio no ciclo de vida organizacional, procurando identificar relações conjuntas entre estas variáveis. Esta análise foi realizada pela aplicação da técnica estatística denominada HOMALS. Já a análise do estágio da instituição no ciclo de vida organizacional foi realizada de forma precedente às duas análises de relacionamento entre variáveis, no entanto, utilizaram-se apenas a frequência das respostas ao questionário, a percepção coletada nas entrevistas e a abordagem teórica norteadora.

Nas seções seguintes são apresentadas estas análises, suscitando discussões subsequentes acerca do relacionamento encontrado e da teoria que embasa as variáveis. Todas as discussões também incluem a percepção qualitativa obtida nas entrevistas com os gestores gerais como contraposição e ou confirmação dos achados, de modo a enriquecer os resultados com o objetivo de promover a generalização teórica, dado que a generalização estatística não será possível em função da natureza do método de pesquisa escolhido.

\subsubsection{Análise do estágio no ciclo de vida organizacional}

Nesta fase, partindo-se da construção da variável do Ciclo de Vida Organizacional que representa a percepção dos colaboradores e gestores acerca do estágio do banco no ciclo de 
vida organizacional, embasado no modelo de Lester, Parnell e Carraher (1993), de acordo com a metodologia de construção delineada anteriormente, procedeu-se à classificação da instituição em um dos estágios do ciclo de vida organizacional.

Para classificar as respostas às questões de acordo com o estágio no ciclo de vida organizacional, foi utilizado o quadro contido na seção A.3.2 do Apêndice 3. Para nenhuma das observações houve empate na frequência dominante de respostas, portanto para cada observação foi possível identificar o estágio dominante com base no conjunto de respostas às questões.

Pelo gráfico a seguir demonstrado, é possível verificar que, na percepção dos colaboradores e gestores das áreas da instituição que participaram da pesquisa, o banco se enquadra entre os estágios de Renovação e Sucesso, dado que os dois dividem a frequência dominante com mais de $44 \%$ dos respondentes em cada um.

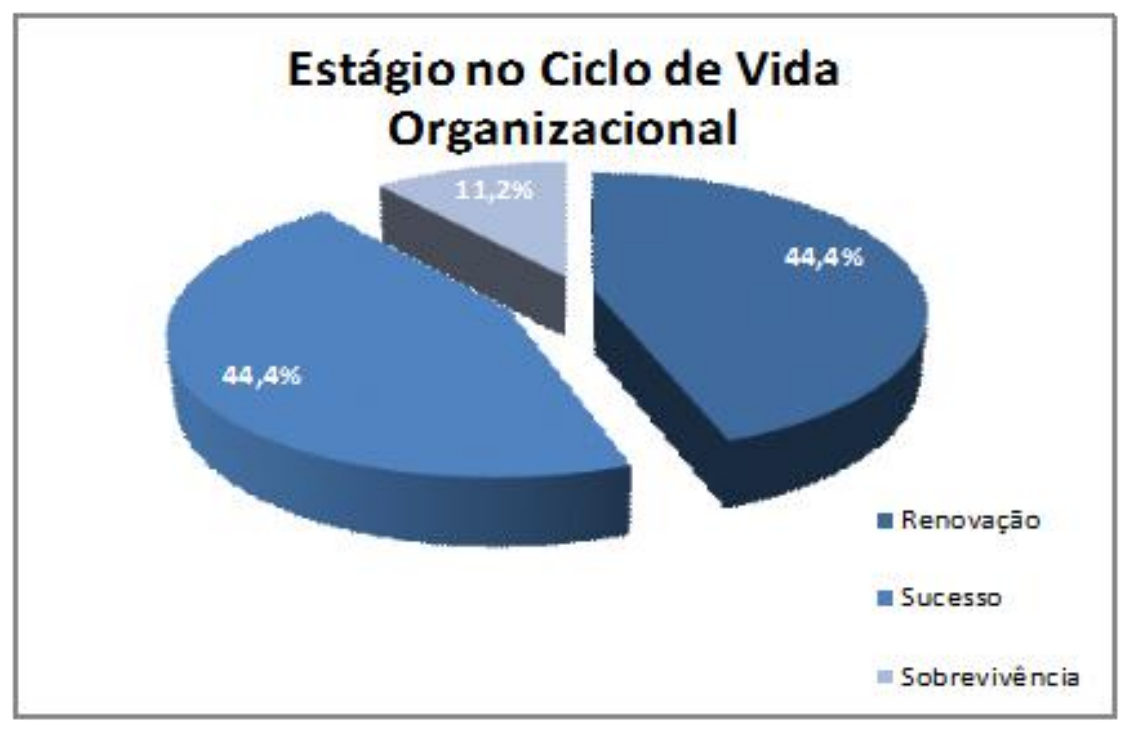

Gráfico 14 - Ciclo de vida organizacional

De forma a analisar estes achados, é importante resgatar os conceitos da abordagem do ciclo de vida organizacional, delineados anteriormente, abordagem esta que Miller e Friesen (1983, 1984) muito contribuíram para desenvolver. Estes conceitos estão dispostos no quadro 1, que resume as características predominantes de cada estágio e que está embasado nos trabalhos de Silvola (2008), Frezatti et al. (2009) e principalmente no trabalho norteador deste estudo 
desenvolvido por Lester, Parnell e Carraher (1993). Este arcabouço permeou as análises dos achados que serão discutidas na sequência desta subseção.

No estágio denominado Renovação predominam características como colaboração, inovação, descentralização do processo decisório, valorização dos clientes, desburocratização, diversificação e utilização de sistemas sofisticados de planejamento e controle. Desta forma, mais de $44 \%$ dos respondentes perceberam estas características bastante positivas como predominantes no banco em análise. Muitas destas características foram confirmadas literalmente pelas entrevistas realizadas com os gestores gerais, entre estas o foco em inovação tecnológica para o cliente, atuação diversificada e abrangente, estruturação e descentralização das decisões.

Entretanto, mais de $44 \%$ dos respondentes percebem a instituição como integrante do estágio denominado Sucesso, no qual predominam características como formalização burocrática, hierarquia altamente formal, instituição de controles, formulação de políticas e procedimentos, foco no planejamento estratégico, e tendência a proteger a riqueza gerada em detrimento de busca por novos mercados. Algumas destas características foram percebidas em parte das percepções obtidas nas entrevistas, na qual foram ressaltadas características como a importância da burocracia para controlar uma grande instituição, o processo de formulação de políticas orientadoras praticado no banco, a intenção estratégica de manter market share, e a existência de certa centralização nas decisões, dado que o processo de descentralização ainda não é integral.

Por estas afirmações, é possível depreender que muitas das características percebidas demonstram que a instituição se encontra num processo evolutivo, ou seja, transitando de estágio. Como exemplo desta informação têm-se a evolução do modelo de gestão, de mais centralizado e burocrático, para mais descentralizado e dinâmico. Além do modelo de gestão, aparentemente evoluindo de um estágio para outro, é possível verificar, pelas percepções contidas nas entrevistas, que a instituição também se encontra evoluindo no que tange à utilização de sistemas de planejamento e controle. 
Adicionalmente também foi possível perceber, pelas afirmações contidas nas respostas ao questionário e à entrevista, a existência de direcionamento quanto às oportunidades de melhoria, estando estas atreladas a projetos que trarão benefícios e evolução para a instituição, suprindo lacunas e contribuindo ainda mais para a consolidação da mudança de estágio. Desta forma, dada a existência de características tanto do estágio denominado como Renovação como do estágio denominado Sucesso, justifica-se a percepção dividida encontrada na análise desta instituição.

Por sua vez, a classificação da instituição no estágio denominado Sobrevivência aparenta não ser plausível quando comparadas as respostas ao questionário com as percepções obtidas pelas entrevistas. Sendo assim, por certo a percepção presente em 11\% dos colaboradores pode ser fruto de uma percepção com um nível crítico elevado, fazendo com que, dadas as respostas, a classificação da instituição recaia a um estágio no ciclo de vida organizacional que não é condizente com a realidade da instituição. Esta dualidade de estágios, associada às percepções captadas por meio das entrevistas, parece indicar que a instituição se encontra efetivamente transitando do estágio denominado Sucesso para o estágio denominado Renovação.

Desta forma, o primeiro objetivo específico, que tinha por finalidade verificar a adequação do modelo de Lester, Parnell e Carraher (1993) que classifica as empresas de acordo com o seu estágio no ciclo de vida organizacional, também é aplicável a instituições financeiras, visto que foi útil e adequado para identificar que o banco em análise encontra-se na transição do estágio denominado Sucesso para o estágio denominado Renovação. Futuramente, o modelo pode ser testado em outras instituições com o intuito de verificar se o achado deste estudo é persistente e pode alçar também a generalização estatística. Outro ponto que pode ser explorado é um eventual aprimoramento do modelo para captar algumas peculiaridades das instituições financeiras, para que, de alguma forma, possa contribuir com um melhor enquadramento destas nos estágios do ciclo de vida organizacional. Todavia, para este caso o modelo possibilitou enquadrar adequadamente a instituição, sem necessidade de aprimoramentos e alterações no modelo.

Outro produto desta análise foi a construção de uma variável denominada Ciclo de Vida Organizacional, que integrou as análises conseguintes e possibilitou verificar a existência de 
relação entre o processo de gestão e controle dos fluxos de caixa e o estágio da instituição no ciclo de vida organizacional, evidenciando a existência ou inexistência de influência entre os elementos contextuais e internos, quer seja esta influência unívoca ou mútua.

\subsubsection{Análise da relação entre o estágio no ciclo de vida organizacional e o processo de gestão e controle dos fluxos de caixa}

Partindo das percepções que foram quantificadas em variáveis, utilizando a regra de formação descrita na subseção 8.3.1, deu-se sequência à análise, inicialmente utilizando a técnica estatística denominada ANACOR para verificar o relacionamento das variáveis, em pares, sendo uma das variáveis o estágio no ciclo de vida organizacional, e a outra variável aquela representativa de uma parcela ou do todo do processo de gestão e controle dos fluxos de caixa. A nomenclatura utilizada para estas variáveis presentes nos outputs sistêmicos é a seguir demonstrada.

Quadro 5 - Variáveis utilizadas

\begin{tabular}{|l|}
\hline \multicolumn{1}{|c|}{ Descrição } \\
\hline Ciclo de Vida Organizacional (estágio) \\
\hline Fluxo de Caixa (Processo de Gestão e Controle dos Fluxos de Caixa) \\
\hline Modelo de Gestão \\
\hline Elementos (Informacionais, Tecnológicos e Técnicos) \\
\hline Utilização (Da Gestão e do Controle do Caixa) \\
\hline
\end{tabular}

Partindo deste modo para a análise destas variáveis, inicialmente se analisou a relação entre a variável que sintetiza o processo de gestão e controle dos fluxos de caixa e a variável que representa o estágio no ciclo de vida organizacional. Com base nos outputs da ANACOR fornecidos pelo software SPSS $®$ (Statistical Package for Social Sciences) se pode observar a relação entre estas duas variáveis. Abaixo estão as evidências encontradas. 
Tabela 2 - Correspondência Fluxo de caixa

\begin{tabular}{|c|c|c|c|c|c|c|}
\hline \multirow{2}{*}{$\begin{array}{l}\text { CICLO DE VIDA } \\
\text { ORGANIZAC. }\end{array}$} & \multicolumn{6}{|c|}{ FLUXO DE CAIXA } \\
\hline & $\begin{array}{l}\text { DISCORDO } \\
\text { TOTALMENTE }\end{array}$ & $\begin{array}{c}\text { DISCORDO } \\
\text { PARCIALMENTE }\end{array}$ & $\begin{array}{l}\text { NEM CONCORDO } \\
\text { NEM DISCORDO }\end{array}$ & $\begin{array}{c}\text { CONCORDO } \\
\text { PARCIALMENTE }\end{array}$ & $\begin{array}{l}\text { CONCORDO } \\
\text { TOTALMENTE }\end{array}$ & Total \\
\hline SOBREVIVENCIA & 1 & 0 & trat & 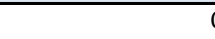 & 1 & 2 \\
\hline SUCESSO & 0 & 1 & . & 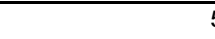 & 1 & 8 \\
\hline RENOVACAO & 0 & 0 & 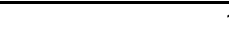 & 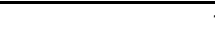 & 6 & 8 \\
\hline Total & 1 & 1 & & 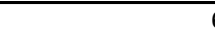 & 8 & 18 \\
\hline
\end{tabular}

Fonte: Output do SPSS $\AA$ adaptado pelo autor

Tabela 3 - Sumário - Estatísticas Fluxo de caixa

\begin{tabular}{|c|c|c|c|c|c|c|c|c|}
\hline \multirow{3}{*}{ Dimensão } & & & & & \multicolumn{2}{|c|}{ Proporção da Inércia } & \multicolumn{2}{|c|}{$\begin{array}{c}\text { Confiança do Valor } \\
\text { Singular }\end{array}$} \\
\hline & & & & & & & & Correlação \\
\hline & $\begin{array}{c}\text { Valor } \\
\text { Singular }\end{array}$ & Inércia & $\begin{array}{c}\text { Qui- } \\
\text { Quadrado }\end{array}$ & Sig. & Individual & Cumulativa & Desv. Pad & 2 \\
\hline 1 & 0,77 & 0,59 & & & 0,63 & 0,63 & 0,12 & 0,87 \\
\hline 2 & 0,58 & 0,34 & & & 0,37 & 1,00 & 0,19 & \\
\hline Total & & 0,93 & 16,78 & 0,03 & 1,00 & 1,00 & & \\
\hline
\end{tabular}

Fonte: Output do SPSS $\AA$ adaptado pelo autor

Pela tabela 2 é possível verificar a correspondência entre as percepções dominantes acerca das características do processo de gestão do caixa e as percepções dominantes acerca do estágio da instituição no ciclo de vida organizacional, em função da concentração de respostas do tipo concordo parcialmente e concordo totalmente, bem como a predominância de classificação nos estágios de sucesso e renovação, conforme já evidenciado na subseção anterior. Já a tabela 3, que apresenta o sumário das estatísticas, demonstra o teste qui-quadrado que rejeitou a hipótese nula de independência entre as variáveis ao nível de 5\% de significância, evidenciando, portanto, a existência de relação entre as duas variáveis analisadas. Abaixo é evidenciada a demonstração gráfica da análise. 
Pontos das Linhas e Colunas

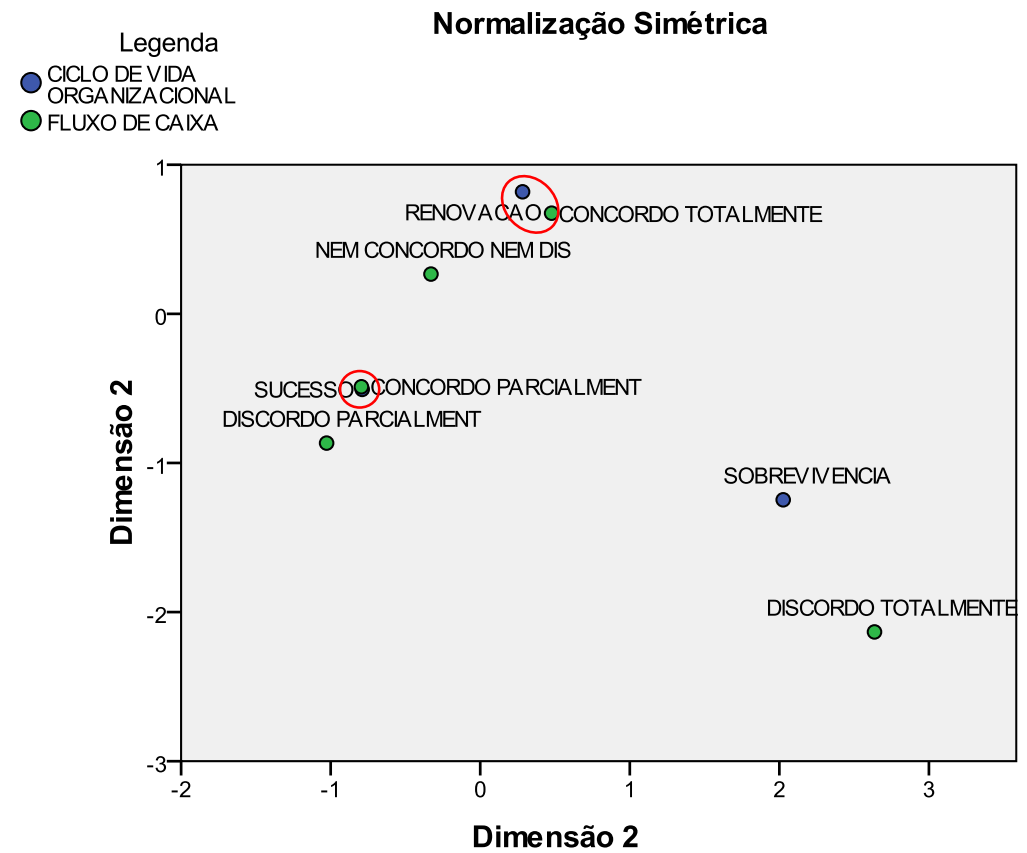

Gráfico 15 - ANACOR Fluxo de caixa

Analisando a representação gráfica acima demonstrada advinda da ANACOR é possível verificar a associação das variáveis denominadas Ciclo de Vida Organizacional e Processo de Gestão e Controle dos Fluxos de Caixa. Pela representação gráfica é possível verificar ao menos duas possíveis associações: o estágio renovação estaria associado com a resposta concordo totalmente, e o estágio sucesso está sobreposto à resposta concordo parcialmente.

Já a não existência de outras associações observáveis deve-se possivelmente à inexistência de dois estágios para este caso, existência e declínio, em função de a percepção dos colaboradores que participaram da pesquisa indicar que a instituição não estaria enquadrada em nenhum destes. Por sua vez, as respostas acerca da variável Fluxo de Caixa, que teoricamente seriam correspondentes a estes estágios, ficam dispersas na representação gráfica e sem associação identificável. Quanto ao estágio denominado Sobrevivência que aparece em duas observações, aparentemente demonstra-se não estar associado diretamente a um tipo de resposta, demonstrando que possivelmente o respondente se mostrou mais crítico quanto às respostas referentes ao estágio no ciclo de vida organizacional se comparadas às respostas referentes ao processo de gestão e controle dos fluxos de caixa. 
Esta associação indica que, dado o modelo de construção das variáveis referentes ao caixa, sendo este baseado na frequência dominante dado um grupo de respostas às questões que representam as variáveis que buscam identificar o construto norteador deste estudo, é possível afirmar que existe relação entre o estágio da instituição no ciclo de vida organizacional e processo de gestão e controle dos fluxos de caixa. Este achado se assemelha a outros estudos, que identificaram a relação entre outros elementos e ferramentas de controle gerencial com estágio da instituição no ciclo de vida organizacional (LESTER; PARNELL; CARRAHER, 1993; MOORES; YUEN, 2001; SOUZA et al., 2007; FREZATTI et al., 2009).

A representação gráfica corrobora o quadro disposto no Apêndice 3 (item A.3.2), que relaciona todas as respostas do questionário com o estágio no ciclo de vida organizacional. Este quadro foi construído levando-se em consideração os elementos teóricos acerca da gestão e controle dos fluxos de caixa contidos nos estudos dos autores que embasaram cada uma das questões conforme evidenciado nos quadros 1 e 3 , tendo como finalidade relacionar as características do processo de gestão e controle dos fluxos de caixa com os conceitos e características de cada um dos estágios do ciclo de vida organizacional.

Os achados também reforçam o construto da seção 6, dado que diversas características que compõem o processo de gestão e controle dos fluxos de caixa, como o modelo de gestão; os elementos informacionais, técnicos e tecnológicos; e a sua utilização, foram identificados na prática em uma instituição, e se mostraram possuidores de relação com estágio da instituição no ciclo de vida organizacional.

Desta forma, consegue-se verificar a existência de associação entre as duas variáveis, sendo possível inferir que o processo de gestão e controle dos fluxos de caixa possui relação com o estágio da organização no ciclo de vida, sendo aderente a este. Este achado, apesar de não ser passível de generalização estatística, pode ser um ponto de partida para uma generalização teórica, visto que integra um conjunto de outros achados de estudos anteriores que envolveram a abordagem teórica do ciclo de vida organizacional e que evidenciaram a associação de ferramentas de gestão e controle gerencial com esta abordagem. 
As respostas às questões referentes ao processo de gestão e controle dos fluxos de caixa também permitiram confirmar a existência e importância de cada uma das características presentes em outros estudos para determinar a conclusão deste trabalho, corroborando com as características encontradas em estudos anteriores (FREZATTI, 1997; PHILLIPS, 1997; HEMPEL; SIMONSON, 1998; SOENEN, 1986; KYTÖNEN, 2004; ITURRALDE; MASEDA; SAN-JOSE, 2008, 2009) e incrementando a vertente de pesquisa que se dispõe a analisar a gestão e controle dos fluxos de caixa pela ótica da observação da prática, tão pouco explorada como indica Kytönen (2004).

Para complementar e esmiuçar a análise, capturando eventuais percepções que são possíveis somente com o fracionamento das variáveis, a variável denominada Fluxo de Caixa foi fracionada em suas componentes, denominadas Modelo de Gestão; Elementos (Informacionais, Tecnológicos e Técnicos) e Utilização. Ainda com o auxílio da ANACOR, esta análise complementar objetivou identificar se as variáveis individualmente poderiam estar associadas ao estágio no ciclo de vida organizacional, ou se somente pela união das variáveis se é possível evidenciar a associação identificada e descrita nos parágrafos anteriores.

Deste modo, as tabelas subsequentes evidenciam as principais características desta análise complementar, demonstrando as tabelas de correspondências, a verificação de independência das variáveis, bem como os mapas perceptuais individuais com a representação gráfica da relação entre as variáveis. A construção de cada variável também ocorreu conforme descrito na subseção 8.3.1, ou seja, um conjunto de questões representa uma variável e a resposta com frequência dominante é considerada a resposta representativa deste grupo para cada variável. Este procedimento difere da análise anterior na qual a resposta com frequência dominante entre as três variáveis é considerada a resposta representativa do processo como um todo.

As tabelas de contingência abaixo representam a correspondência entre os pares de variáveis, na qual sempre a variável representativa do ciclo de vida organizacional é uma das componentes. Por estas tabelas é possível observar que as variáveis denominadas Modelo Gerencial e Utilização possuem concentração nas duas últimas categorias, concordo parcialmente e concordo totalmente; enquanto a variável denominada Elementos Informacionais, Tecnológicos e Técnicos tem grande dispersão entre as alternativas. 
Entretanto apenas para a variável com maior dispersão pode ser rejeitada a hipótese nula de independência das variáveis ao nível de significância de 5\% demonstrando que, possivelmente, as variáveis denominadas Modelo de Gestão e Utilização, quando analisadas de forma isolada, não possuem relação robusta com a variável denominada Ciclo de Vida Organizacional.

Tabela 4 - Correspondência Modelo de gestão

\begin{tabular}{|c|c|c|c|c|c|c|}
\hline \multirow{2}{*}{$\begin{array}{l}\text { CICLO DE VIDA } \\
\text { ORGANIZAC. }\end{array}$} & \multicolumn{5}{|c|}{ MODELO GERENCIAL } & \multirow[b]{2}{*}{ Total } \\
\hline & $\begin{array}{l}\text { DISCORDO } \\
\text { TOTALMENTE }\end{array}$ & $\begin{array}{c}\text { DISCORDO } \\
\text { PARCIALMENTE }\end{array}$ & $\begin{array}{l}\text { NEM CONCORDO } \\
\text { NEM DISCORDO }\end{array}$ & $\begin{array}{l}\text { CONCORDO } \\
\text { PARCIALMENTE }\end{array}$ & $\begin{array}{c}\text { CONCORDO } \\
\text { E TOTALMENTE }\end{array}$ & \\
\hline SOBREVIVENCIA & 0 & 0 & & 0 & 2 & 2 \\
\hline SUCESSO & 0 & 0 & & 0 & 5 & 8 \\
\hline RENOVACAO & 0 & 0 & & 0 & 1 & 8 \\
\hline TOTAL & 0 & 0 & & 0 & 12 & 18 \\
\hline
\end{tabular}

Fonte: Output do SPSS $\AA$ adaptado pelo autor

Tabela 5 - Correspondência Elementos informacionais, tecnológicos e técnicos

\begin{tabular}{|c|c|c|c|c|c|c|}
\hline \multirow{2}{*}{$\begin{array}{l}\text { CICLO DE VIDA } \\
\text { ORGANIZAC. }\end{array}$} & \multicolumn{6}{|c|}{ ELEMENTOS } \\
\hline & $\begin{array}{l}\text { DISCORDO } \\
\text { TOTALMENTE }\end{array}$ & $\begin{array}{c}\text { DISCORDO } \\
\text { PARCIALMENTE }\end{array}$ & $\begin{array}{l}\text { NEM CONCORDO } \\
\text { NEM DISCORDO }\end{array}$ & $\begin{array}{c}\text { CONCORDO } \\
\text { PARCIALMENTE }\end{array}$ & $\begin{array}{l}\text { CONCORDO } \\
\text { TOTALMENTE }\end{array}$ & Total \\
\hline SOBREVIVENCIA & 1 & 0 & 1 & 0 & 0 & 2 \\
\hline SUCESSO & 0 & 2 & 1 & 4 & 1 & 8 \\
\hline RENOV ACAO & 0 & 0 & 2 & 2 & 4 & 8 \\
\hline Total & 1 & 2 & 4 & 6 & 5 & 18 \\
\hline
\end{tabular}

Fonte: Output do SPSS $\AA$ adaptado pelo autor

Tabela 6 - Correspondência Utilização

\begin{tabular}{|c|c|c|c|c|c|c|}
\hline \multirow[b]{2}{*}{$\begin{array}{l}\text { CICLO DE VIDA } \\
\text { ORGANIZAC. }\end{array}$} & \multicolumn{6}{|c|}{ UTILIZAÇÃO } \\
\hline & $\begin{array}{c}\text { DISCORDO } \\
\text { TOTALMENTE }\end{array}$ & $\begin{array}{c}\text { DISCORDO } \\
\text { PARCIALMENTE }\end{array}$ & $\begin{array}{l}\text { NEM CONCORDO } \\
\text { NEM DISCORDO }\end{array}$ & $\begin{array}{c}\text { CONCORDO } \\
\text { PARCIALMENTE }\end{array}$ & $\begin{array}{l}\text { CONCORDO } \\
\text { TOTALMENTE }\end{array}$ & Total \\
\hline SOBREVIVENCIA & 0 & 0 & 0 & ) & 1 & 2 \\
\hline SUCESSO & 0 & 1 & 1 & 3 & 3 & 8 \\
\hline RENOVACAO & 0 & 0 & 1 & 1 & 6 & 8 \\
\hline Total & 0 & 1 & 2 & 5 & 10 & 18 \\
\hline
\end{tabular}

Fonte: Output do SPSS $\odot$ adaptado pelo autor 
Tabela 7 - Estatísticas variáveis

\begin{tabular}{|c|c|c|c|c|c|c|c|c|c|}
\hline \multicolumn{4}{|c|}{ Modelo de Gestão } & \multicolumn{3}{|c|}{ Eementos } & \multicolumn{3}{|c|}{ Utilização } \\
\hline \multirow[b]{2}{*}{ Dimensão } & & & $\begin{array}{l}\text { Proporção } \\
\text { da Inércia }\end{array}$ & & & $\begin{array}{l}\text { Proporção } \\
\text { da Inércia }\end{array}$ & & & $\begin{array}{l}\text { Proporção } \\
\text { da Inércia }\end{array}$ \\
\hline & Inércia & $\begin{array}{l}\text { Sig Qui- } \\
\text { Quadrado }\end{array}$ & Individual & Inércia & $\begin{array}{l}\text { Sig Qui- } \\
\text { Quadrado }\end{array}$ & Individual & Inércia & $\begin{array}{l}\text { Sig Qui- } \\
\text { Quadrado }\end{array}$ & Individual \\
\hline 1 & 0,31 & & 1,00 & 0,59 & & 0,67 & 0,17 & & 0,81 \\
\hline 2 & & & & 0,29 & & 0,33 & 0,04 & & 0,19 \\
\hline Total & 0,31 & 0,689 & 1,00 & 0,87 & 0,047 & 1,00 & 0,21 & 0,873 & 1,00 \\
\hline
\end{tabular}

Sendo assim, a verificação individual de cada uma das três variáveis formadoras do processo de gestão e controle dos fluxos de caixa retorna em conclusão estatística não significante para este caso, demonstrando que o processo como um todo possui forte relação com o estágio da instituição no ciclo de vida organizacional, porém que as variáveis isoladas não apresentam em sua totalidade a mesma relação. Entretanto, apesar de não apresentarem significância estatística, os mapas perceptuais em sua representação gráfica trazem alguma reflexão contributiva para o estudo.

Como se pode observar a seguir, os gráficos que representam o mapa perceptual da ANACOR demonstram certa relação entre as duas alternativas mais escolhidas, concordo totalmente e concordo parcialmente, com estágios de Renovação e Sucesso respectivamente, ao menos para duas variáveis (Elementos e Utilização).

A proximidade gráfica entre os pontos supracitados estão demarcadas por círculos vermelhos e, apesar da limitação estatística apontada na tabela 7, demonstram alguma relação entre as categorias das variáveis. Pela visualização dos mapas perceptuais abaixo apresentados é possível perceber certa relação entre as características do processo de gestão e controle dos fluxos de caixa, neste caso, dos elementos informacionais, tecnológicos e técnicos, bem como da utilização, com os estágios da organização no ciclo de vida organizacional, denominados sucesso e renovação, demonstrando certa relação gráfica apesar da relação estatística não ser confirmada. 


\section{Pontos das Linhas e Colunas}

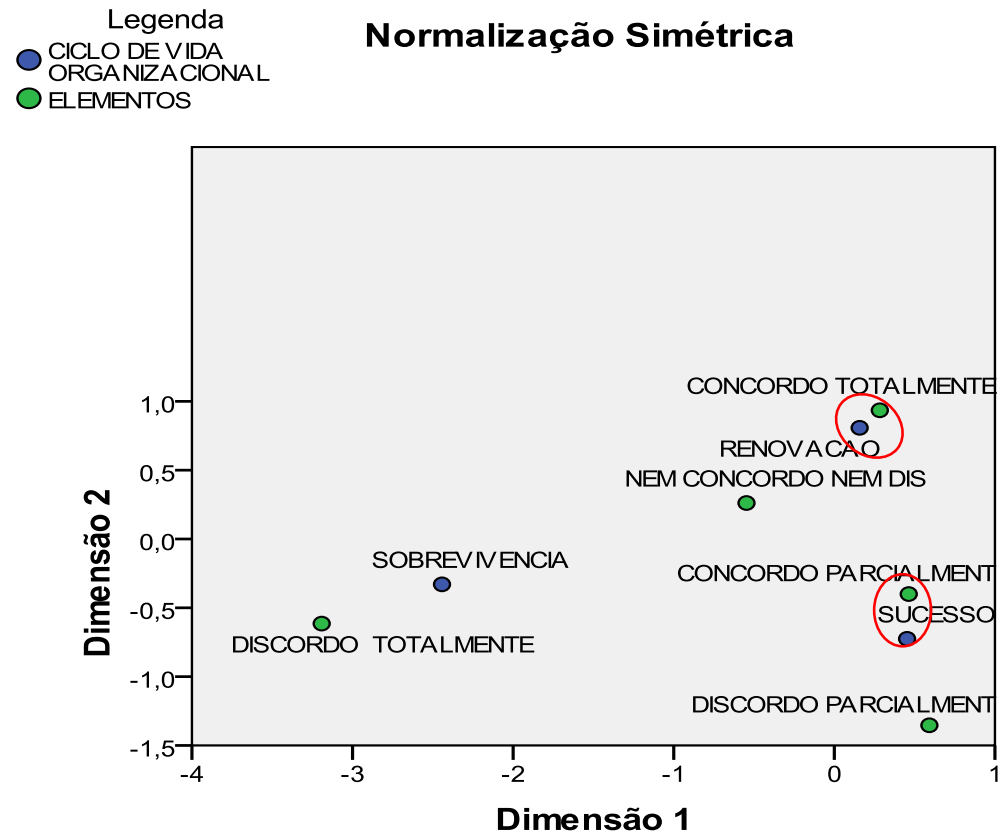

Gráfico 16 - ANACOR Elementos

\section{Pontos de Linhas e Colunas}

\section{Legenda}

\section{ICLO DEVIDA}

ORGANIZACIONAL

O UTILIZAÇÃO

\section{Normalização Simétrica}

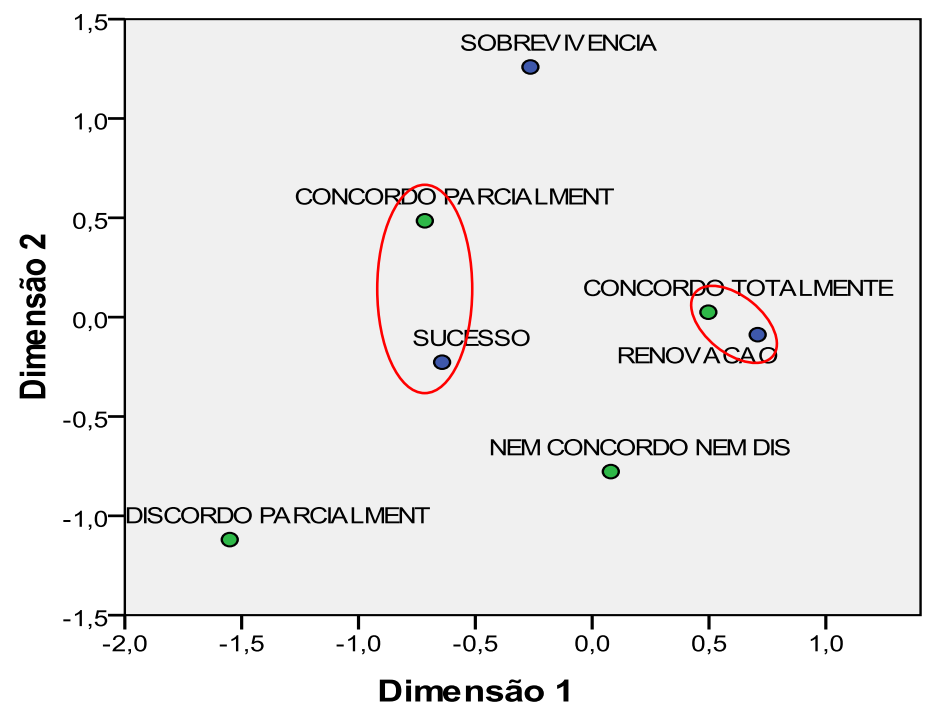

Gráfico 17 - ANACOR Utilização 
Por fim, como última análise complementar, foi realizada uma análise estatística do tipo HOMALS (Análise de Homogeneidade), reunindo três variáveis representantes do processo de gestão e controle dos fluxos de caixa e a variável representante do estágio da instituição no ciclo de vida organizacional.

Esta análise, presente no gráfico a seguir, demonstrou certa associação entre o estágio denominado Renovação e a categoria representada pela alternativa concordo totalmente. Já o estágio Sucesso se mostrou em parte associado à categoria representada pela alternativa concordo parcialmente, visto que a variável Utilização se apresentou dispersa em relação a este grupo. A região delimitada pela linha vermelha representa a relação parcial e a região delimitada pela linha azul representa a relação mais robusta.

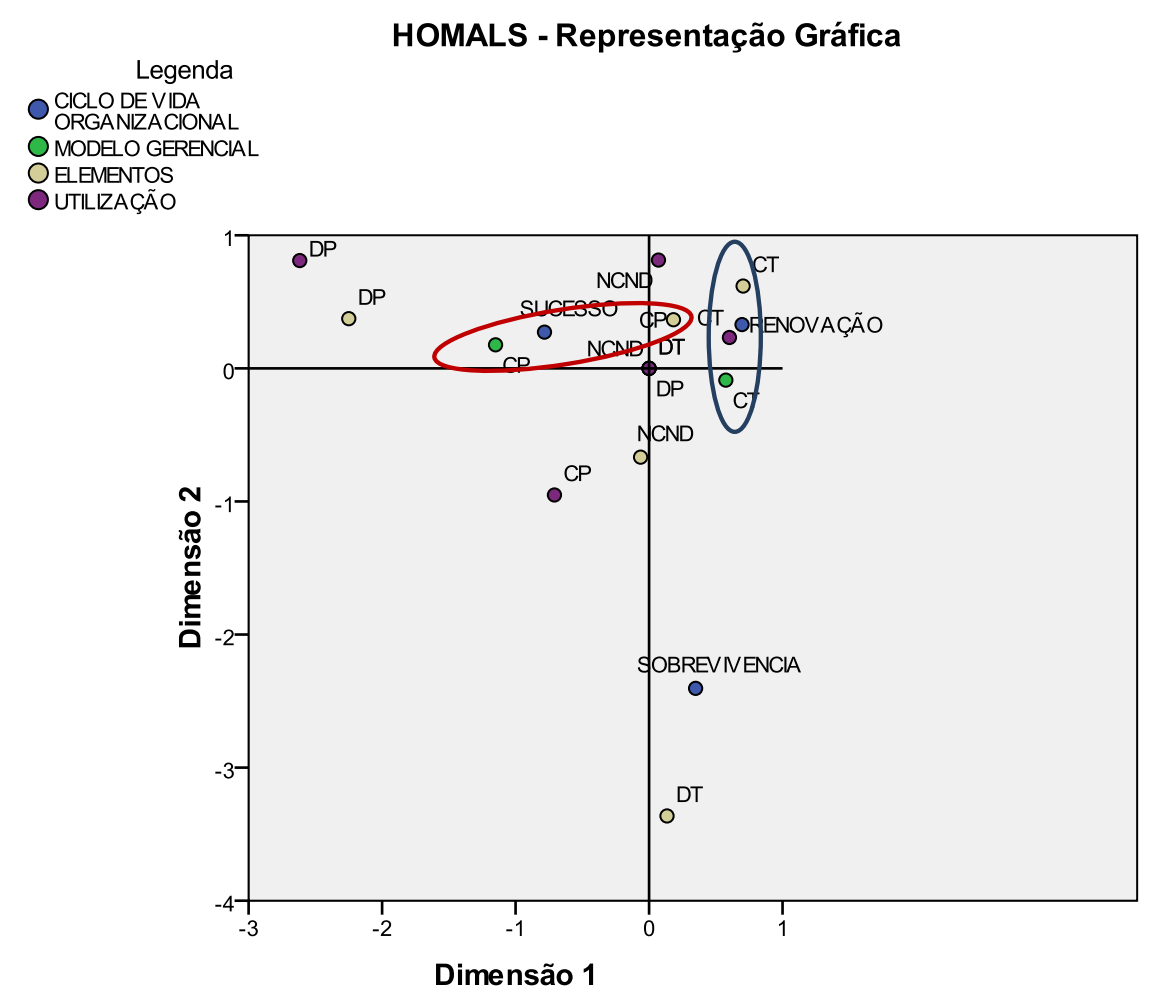

Gráfico 18 - HOMALS Variáveis

Deste modo, após várias análises estatísticas embasadas nas percepções advindas das respostas dos colaboradores e gestores envolvidos no processo de gestão e controle dos fluxos 
de caixa ao questionário que se dispôs a capturar as percepções acerca do estágio da instituição no ciclo de vida organizacional e das características formadoras do processo de gestão e controle dos fluxos de caixa, é possível afirmar que, se considerado o processo como um todo, existe relação entre a gestão e controle do caixa e o estágio da instituição no ciclo de vida organizacional, sendo este achado confirmado pela ANACOR realizada entre a variável Fluxo de Caixa e a variável Ciclo de Vida Organizacional.

Este achado também é reforçado em parte pela HOMALS realizada entre as três grandes variáveis que compõem o processo de gestão e controle dos fluxos de caixa, Modelo de Gestão, Elementos e Utilização, pois o gráfico demonstra associação com o ciclo de vida para a maioria delas. Todavia, se consideramos a relação de cada uma destas três variáveis individualmente com o estágio da instituição no ciclo de vida organizacional, pela aplicação da ANACOR, não se encontra relação estatística significativa entre as variáveis, apesar de a representação gráfica também evidenciar certa relação para duas das três variáveis, sendo estas a variável denominada Modelo de Gestão e a variável denominada Utilização.

Para complementar os achados estatísticos, antes de tecer a conclusão final sobre este achado que responderá à questão de pesquisa e atenderá o objetivo ainda não concluído deste trabalho, é importante adicionar alguns destaques das percepções dos gestores gerais acerca da temática, contribuindo para confirmar os achados estatísticos. Por estas percepções é possível inferir também que o estágio no ciclo de vida possua influência na formatação e utilização do processo. Esta inferência se baseia nas percepções obtidas nas entrevistas, pois estas demonstraram, de certa forma, que, em função da aparente transição de estágio, a instituição tem iniciado diversas mudanças para adequar o seu processo de gestão e controle dos fluxos de caixa as suas novas necessidades.

Especificamente em relação ao processo de gestão e controle dos fluxos de caixa se pode observar que, na percepção dos gestores gerais, salvo as oportunidades de melhoria presentes em qualquer processo, sendo a maioria destas, de alguma forma, alvo de mudanças e projetos já iniciados, o processo de gestão e controle dos fluxos de caixa está adequadamente formatado em cada uma das suas variáveis, ou seja, possui adequado modelo que permite gestão e controle ótimos dos fluxos de caixa; utiliza adequados elementos informacionais, técnicos e tecnológicos, de modo que estes atendem em linhas gerais as necessidades da 
instituição; e possui também adequada finalidade de utilização, propiciando o efeito esperado nas áreas que coordenam e que participam da gestão e controle do caixa.

As oportunidades de melhoria citadas pelos gestores gerais estão bastante ligadas às mudanças de filosofia e ao próprio crescimento da instituição que requerem as transformações sistêmicas e culturais que já vêm sendo desenvolvidas. Sendo assim, estas características aparentam estreito relacionamento com o estágio da instituição no ciclo de vida organizacional, que aparentemente se encontra transitando do estágio denominado Sucesso para o estágio denominado Renovação. Deste modo, dados os achados estatísticos supracitados e as percepções advindas das entrevistas é possível afirmar que, para o caso analisado, o processo de gestão e controle dos fluxos de caixa é aderente ao estágio da instituição no ciclo de vida organizacional, estando estes relacionados de alguma forma.

Em função desta condição, é possível inferir que essa relação ocorre de forma que as variáveis que compõem o processo, como o modelo de gestão, os elementos informacionais, tecnológicos e técnicos, bem como sua finalidade e grau de utilização na instituição sofrem influências e transformações de modo a atender as necessidades da instituição, observado que estas necessidades, de algum modo, são afetadas pelos fatores contextuais, como direcionamento estratégico, ambiente em que está inserido, crescimento, entre outros fatores que, por sua vez, determinam o seu estágio no ciclo de vida organizacional.

\subsection{Discussão}

Retomando os principais achados contrastados com a questão de pesquisa e os objetivos deste estudo, tornou-se possível tecer algumas considerações acerca destes. Inicialmente, observouse que foi possível aplicar, de forma inédita, o modelo de enquadramento de empresas em estágios do ciclo de vida organizacional desenvolvido por Lester, Parnell e Carraher (1993) para classificar também uma instituição financeira, com base nas percepções dos colaboradores, gestores das áreas e gestores gerais captadas por meio do questionário e das entrevistas, atendendo parcialmente ao objetivo geral e o primeiro objetivo específico. 
Este achado indicou a possibilidade de utilização deste modelo para classificar outras instituições financeiras em estudos futuros, visto que, em estudos anteriores, estes modelos se debruçavam em classificar empresas não financeiras. Entretanto apesar de uma instituição financeira apresentar suas peculiaridades quando comparada a outros segmentos, o modelo de Lester, Parnell e Carraher (1993) não necessitou de adaptações teóricas para ser utilizado neste estudo de caso, demonstrando sua versatilidade quanto ao universo de pesquisa em potencial.

Também com base nas percepções dos participantes da pesquisa, foi possível encontrar evidências sobre a aderência do processo de gestão e controle dos fluxos de caixa ao estágio da instituição no ciclo de vida organizacional. Estas percepções se demonstraram bem uníssonas, pois apesar de se tratar de uma instituição financeira de grande porte, não havia divergência significativa de percepção entre as áreas de finanças, riscos, tesouraria em relação ao processo de gestão e controle dos fluxos de caixa e ao estágio percebido da instituição no ciclo de vida organizacional, permitindo que os achados deste estudo de caso pudessem ser mais robustos, dado que a percepção das áreas reflete em linhas gerais a percepção da instituição com um todo.

Pelos achados obtidos por estas percepções é possível inferir que, assim como outras ferramentas e processos, o processo de gestão e controle dos fluxos de caixa está relacionado de alguma forma ao estágio da instituição no ciclo de vida organizacional, como evidenciado por diversos autores em outros estudos com outras ferramentas de gestão e controle (LESTER; PARNELL; CARRAHER, 1993; MOORES; YUEN, 2001; SOUZA et al., 2007; FREZATTI et al., 2009). Este achado contribuiu para responder o restante do objetivo principal, o terceiro objetivo específico e a questão de pesquisa, demonstrando que para o caso em estudo o processo de gestão e controle dos fluxos de caixa é aderente ao estágio da instituição no ciclo de vida organizacional, havendo, portanto relacionamento entre as variáveis tratadas, conforme delineado no construto teórico.

Entretanto, apenas pela abordagem teórica não é possível afirmar unicamente que o processo de gestão e controle dos fluxos de caixa sofre influência do estágio da instituição no ciclo de vida organizacional, dados os fatores contextuais que delimitam este estágio, ou se de alguma forma as ferramentas de gestão e controle também podem influenciar a mudança de estágio. 
Partindo desta inquietação é possível tecer algumas hipóteses teóricas, que podem orientar ou serem objetos de pesquisas futuras.

Caso os fatores contextuais que determinam o estágio da instituição no ciclo de vida organizacional se alterem, os processos de gestão e controle tenderão a sofrer transformações para suportar o desenvolvimento da instituição em caso de evolução ou tenderão a se retraírem em caso de decadência. Entretanto, foi possível constatar que mesmo para um mesmo processo, no caso deste estudo, o processo de gestão e controle dos fluxos de caixa, não existe uma evolução homogênea em todas as características, sendo que algumas delas se apresentam em formas diferentes da que se espera para o estágio atual da instituição.

Estas divergências de certas características poderão de alguma forma afetar os objetivos gerais da organização, dado que de acordo com a abordagem teórica, os objetivos organizacionais estratégicos e táticos aliados a outros fatores, de alguma forma definem o estágio em que a organização se encontra, e o fato de que suas ferramentas e processo de controle e gestão não se apresentarem totalmente aderentes ao seu estágio no ciclo de vida organizacional, podem de alguma forma constituir um empecilho para o alcance dos objetivos organizacionais e até mesmo frear a evolução da organização no ciclo de vida organizacional (LESTER; PARNELL; CARRAHER, 1993; MOORES; YUEN, 2001; MILLER e FRIESEN, 1983, 1984).

Partindo, então para uma afirmação mais incisiva, caso uma ferramenta de gestão e controle, como o processo de gestão e controle dos fluxos caixa, possua tanta importância que possa influenciar a evolução ou decadência da instituição no ciclo de vida organizacional, seria importante prepará-la para fomentar a evolução da instituição, direcionando as características destas para atender os objetivos organizacionais, de modo que a ferramenta nunca esteja defasada e não aderente aos objetivos pretendidos pela instituição.

Deste modo, levando-se em consideração estas hipóteses, especificamente para este caso, seria possível afirmar que para uma instituição financeira seria interessante conhecer seu estágio no ciclo de vida organizacional, para que primeiramente ela pudesse identificar se o estágio de desenvolvimento em que ocupa atualmente condiz com suas pretensões e em 
seguida compreender o que precisa ser aprimorado e desenvolvido para manter ou evoluir a sua posição no ciclo de vida organizacional.

Conhecido seu estágio, em função da relação encontrada com o processo de gestão e controle dos fluxos de caixa, a instituição deveria formatá-lo para que este pudesse atender as necessidades do estágio do ciclo de vida organizacional em que ela se encontra, e numa visão de médio e longo prazo, promover os incrementos necessários para que este acompanhe ou até fomente o desenvolvimento da instituição no ciclo de vida organizacional, não permitindo de forma alguma que o processo de gestão e controle dos fluxos de caixa, seja subutilizado e não aderente ao seu desenvolvimento.

Em suma, estas considerações podem significar que desconhecer seu estágio no ciclo de vida, e desconhecer a aderência de suas ferramentas e controles gerenciais a este podem trazer consequências às empresas, dado que este conhecimento e o alinhamento das ferramentas gerenciais com o estágio no ciclo de vida organizacional possivelmente permitirão maior congruência de objetivos e até mesmo otimização de resultados. Dados os achados de outros estudos (MOORES e YUEN, 2001; SOUZA et al., 2007; FREZATTI et al., 2009) é possível inferir que outras ferramentas de gestão e controle também possam possuir o mesmo comportamento.

Sendo assim, futuras pesquisas podem debruçar-se na possibilidade de verificar de que forma ocorre a relação entre as ferramentas gerenciais e o estágio da instituição no ciclo de vida organizacional, desvendando quem influencia, quem é influenciado, e como interferir beneficamente nesta relação de modo a promover o desenvolvimento da instituição, confirmando ou refutando as hipóteses sugeridas nesta subseção, acerca da aderência de um processo de gestão ao estágio no ciclo de vida organizacional e suas implicações.

Não menos importante foi verificar a aplicabilidade do construto que delimitava a análise do processo de gestão e controle dos fluxos de caixa, sendo este subdividido em variáveis e estas embasadas em diferentes estudos acerca do caixa (FREZATTI, 1997; PHILLIPS, 1997; HEMPEL; SIMONSON, 1998; SOENEN, 1986; KYTÖNEN, 2004; ITURRALDE; MASEDA; SAN-JOSE, 2008, 2009). Esta verificação ocorreu em função da aplicação do questionário e das entrevistas, visto que o construto que permeava as questões e entrevistas 
foi compreendido pelos respondentes e entrevistados, e verificou-se sua utilização na prática, atendendo ao segundo objetivo específico.

Deste modo é possível inferir que o construto delineado exista de fato, e que seja encontrado na prática da gestão do caixa na instituição em análise, numa formatação bem próxima à idealizada neste estudo, demonstrando que os estudos científicos acerca da gestão e controle do caixa se aproximam da realidade encontrada na prática. Este achado suscita a hipótese de que este construto possa ser encontrado na integra ou parcialmente também em outras instituições financeiras e não financeiras em pesquisas futuras. A constatação da utilização do construto idealizado na prática em uma instituição une-se aos poucos estudos realizados com o intuito de analisar a gestão do caixa pela ótica da prática, visto que a pesquisa cientifica pouco tem investigado esta vertente conforme afirmação de Kitönen (2004).

Também é importante ressaltar que foi possível evidenciar que as temáticas de risco de liquidez, da influência dos mecanismos regulatórios, e do controle gerencial, presentes no embasamento teórico deste estudo, foram encontradas de fato na prática permeando o processo de gestão e controle dos fluxos de caixa da instituição pesquisada, nas respostas ao questionário, nas afirmações coletadas nas entrevistas e na formatação das áreas e do processo. Estas temáticas também podem ser exploradas mais profundamente em pesquisas futuras, para elucidar a influência específica da regulação, dos conceitos e práticas de risco, ou de outras abordagens teóricas de controle gerencial sobre o processo de gestão controle dos fluxos de caixa.

Outro objetivo alcançado, secundário, porém interessante, foi a constatação da participação do orçamento no processo de gestão e controle dos fluxos de caixa na instituição pesquisada, seja de forma direta como fonte de informação, seja como uma fonte de comparação para suscitar questionamentos, ou mesmo como ferramenta capaz de integrar indicadores que relacionem o caixa ao retorno. Este achado também reforça outros estudos que evidenciaram a participação do orçamento na gestão do caixa (SOENEN, 1986; PHILLIPS, 1997; KYTÖNEN, 2004; ITURRALDE; MASEDA; SAN-JOSE, 2009).

Este achado também suscita a dúvida sobre o papel do orçamento na gestão do caixa, de como as limitações advindas das reservas orçamentárias não prejudicam as projeções futuras de 
caixa, e de como o controle do caixa e as projeções orçamentárias podem se integrar. Ressalta-se, contudo que tanto o uso como a finalidade do orçamento, citadas em diversos estudos conforme supracitados requerem pesquisas futuras se a intenção for a generalização estatística deste achado.

Desta forma, o estudo contribuiu para identificar a aderência do processo de gestão e controle dos fluxos de caixa ao estagio da instituição estudada no ciclo de vida organizacional, demonstrando a aplicabilidade de um modelo e de um construto, que permitem a construção de diversas hipóteses e inferências ligadas a estes achados. Estas hipóteses e inferências ensejarão maiores aprofundamentos e pesquisas, porém podem contribuir para maior entendimento do processo de gestão e controle dos fluxos de caixa, da utilidade e importância da abordagem do ciclo de vida organizacional e das implicações benéficas e prejudiciais advindas da relação entre estas duas temáticas. Deste modo este estudo exploratório poderá tornar-se um ponto de partida para diversas outras pesquisas que aprofundem estas inquietações. 


\section{CONSIDERAÇÕES FINAIS}

Inicialmente é importante ressaltar que transpor a barreira da desconfiança, dado que a temática é vista como confidencial e estratégica entre as instituições financeiras, foi fundamental para o sucesso da pesquisa. A disposição de uma instituição em participar do estudo, desde que não fosse identificada, tornou viável o estudo, com a aplicação da estratégia do estudo de caso, permitindo contribuições valiosas ao problema analisado. Todavia, tornase necessário ressaltar que todos os achados e análises da pesquisa estão pautados na percepção dos respondentes do questionário e dos entrevistados e, portanto, sujeitos às suas crenças, valores e princípios.

Como segunda consideração, ressalta-se que o modelo de enquadramento de empresas em estágios do ciclo de vida organizacional desenvolvido por Lester, Parnell e Carraher (1993) não necessitou de adaptações teóricas para ser utilizado neste estudo de caso, demonstrando sua versatilidade quanto ao universo de pesquisa em potencial, possibilitando classificar uma instituição financeira apesar de suas peculiaridades quando comparada a empresas de outros segmentos, diferentemente de estudos anteriores, em que estes modelos se debruçavam em classificar empresas não financeiras. Este modelo foi um dos alicerces para o desenvolvimento do construto teórico que embasou todas as análises desta pesquisa.

Uma das principais contribuições deste estudo reside no construto proposto, que embasado em diversas pesquisas e achados empíricos esparsos, se dispôs a relacionar o processo de gestão e controle dos fluxos de caixa ao estágio da instituição no ciclo de vida organizacional, contendo diversos detalhes e características tanto do processo quanto do estágio, sendo estes necessários para a análise, constituindo-se em um arcabouço teórico proposto para o estudo deste caso e possivelmente para outras pesquisas futuras, dado que a pesquisa científica pouco tem se debruçado acerca dos estudos relacionados à pratica da gestão do caixa.

Inicialmente foi possível constatar a aplicabilidade deste construto pela compreensão dos respondentes e entrevistados, trazendo indícios da aplicabilidade do modelo apresentado. Entretanto, dada a sua característica analítica e dada a possibilidade de rastreamento e entendimento das origens do modelo, sendo estas expostas detalhadamente durante este estudo, é possível inferir que além de útil para este caso ele possa ser um ponto de partida 
para diversas pesquisas acerca da temática e quiçá ser utilizado integralmente na sua configuração inicial.

Todavia, assim como o modelo de análise é uma das virtudes do trabalho, também pode ser considerada uma das suas principais limitações, visto que há sempre um risco na tentativa de se concatenar proposições de diferentes autores e estudos, o que poderia induzir a análises questionáveis. Deste modo, abrem-se oportunidades de pesquisas futuras explorarem o construto apresentado, verificando se as características propostas pelo modelo são encontradas na prática nos processos de gestão e controle dos fluxos de caixa de empresas que atravessam cada um dos estágios do ciclo de vida organizacional, confirmando, refutando ou complementando as proposições delineadas, além de proporcionar o aprimoramento do modelo apresentado neste estudo.

Com base na análise do caso à luz do construto teórico desenvolvido, foi possível encontrar evidências sobre a aderência do processo de gestão e controle dos fluxos de caixa ao estágio da instituição no ciclo de vida organizacional, com percepções bastante convergentes entre as áreas da instituição financeira pesquisada, mesmo sendo esta uma empresa de grande porte, trazendo, portanto, robustez aos achados, visto que a percepção das áreas refletiu predominantemente a percepção da instituição como um todo. Este achado vai ao encontro de outros estudos que similarmente evidenciaram a relação de ferramentas de gestão e controle com o estágio da instituição no ciclo de vida organizacional.

Entretanto, não foi possível afirmar se a relação de influência entre o processo de gestão e controle dos fluxos de caixa e o ciclo de vida organizacional é recíproca ou unidirecional. Desta forma, é possível o processo de gestão e controle dos fluxos de caixa tornar-se um empecilho ou um propulsor para a evolução da instituição no ciclo de vida organizacional, assim como o estágio no ciclo de vida organizacional pode, de alguma forma, influenciar a formatação deste processo e de outras ferramentas gerenciais, sendo estas oportunidades para que pesquisas futuras possam desvendar de que maneira ocorre esta relação.

Todavia, partindo da proposição da relação encontrada neste estudo de caso, embasada no construto teórico delineado, desconhecer seu estágio no ciclo de vida e desconhecer a aderência de suas ferramentas e controles gerenciais ao seu estágio podem trazer 
consequências às empresas, passando por questões como a incongruência entre objetivos corporativos, departamentais e ferramentas gerenciais; conflitos internos decorrentes de visões divergentes sobre a efetividade do processo de controle gerencial e até mesmo à destruição de valor agregado.

Outra interessante constatação trata-se da participação do orçamento no processo de gestão e controle dos fluxos de caixa na instituição pesquisada, seja como fonte de informação, de comparação para suscitar questionamentos, ou mesmo como ferramenta capaz de integrar indicadores que relacionem o caixa ao retorno. Este achado une-se a outros estudos que demonstram como o orçamento pode superar o preconceito, desconfiança e o rótulo de ferramenta estática, e se integrar ao processo de gestão e controle dos fluxos de caixa, graças a técnicas como rolling forecast.

Sendo assim, este estudo, ainda que exploratório, trouxe contribuições importantes para aprofundar a discussão acerca do problema de pesquisa proposto, constituindo um ponto de partida para diversas outras pesquisas que se interessem, por exemplo, em explorar as proposições apresentadas, desenvolver o modelo teórico proposto ou buscar respostas para as lacunas existentes. 


\section{REFERÊNCIAS}

ACHARYA, V.; NAQVI, H. The seeds of a crisis: a theory of bank liquidity and risk-taking over the business cycle. Centro de Estudios Monetarios y Financieros, 2010. Disponível em: <http://www.bis.org/repofficepubl/hkimr201007.09.pdf>. Acesso em: 25/09/2011.

ALCÂNTARA, W. R. A probabilidade de falha por falta de liquidez em bancos comerciais. VII Encontro Brasileiro de Finanças, São Paulo, 2007. Disponível em: $<$ http://bibliotecadigital.fgv.br/ocs/index.php/ebf/7EBF/paper/viewFile/1793/903>. Acesso em: 29/03/2011

ALVES, L. C. O.; MARQUES, J. A. V. C. Identificação das fases do ciclo de vida de empresas através da análise das demonstrações dos fluxos de caixa. BASE - Revista de Administração e Contabilidade da Unisinos. São Leopoldo - RS, v. 4, n. 3, set./dez. 2007.

ANSOFF, H. I.; DECLERCK, R. P.; HAYES, R. L. From strategic planning to strategic management. New York: John Wiley e Sons, 1976.

ASSAF NETO, A. Estrutura e análise de balanços: um enfoque econômico-financeiro. 8. ed. São Paulo: Atlas, 2006a.

ASSAF NETO, A. Finanças corporativas e valor. 2. ed. São Paulo: Atlas, 2006b.

AUZAIR. S. M.; LANGFIELD-SMITH, K. The effect of service process type, business strategy and life cycle stage on bureaucratic MCS in service organizations. Management Accounting Research. v. 16, n. 4, p. 399-421, 2005.

BACEN. Bancos brasileiros após a Resolução 1524, de 21.09.88 - Sistema Financeiro Nacional de 1989 a 2000. 2000. Disponível em: <http://www.bcb.gov.br/htms/Deorf/e882000/texto.asp?idpai=relsfn19882000>. Acesso em: 30/11/2011.

BACEN. Relação de instituições em funcionamento no país. 2010. Disponível em: <http://www.bcb.gov.br/fis/info/instituicoes.asp>. Acesso em: 19/11/2010.

BANCO CENTRAL DO BRASIL. Conselho Monetário Nacional. Resolução 1.524/1988. Disponível em: < http://www.bcb.gov.br/pre/normativos/res/1988/pdf/res_1524_v1_O.pdf >. Acesso em 26/10/2011.

BANCO CENTRAL DO BRASIL. Conselho Monetário Nacional. Resolução 2.099/1994. Disponível em: < http://www.bcb.gov.br/pre/normativos/res/1994/pdf/res_2099_v1_O.pdf >. Acesso em 26/10/2011. 
BANCO CENTRAL DO BRASIL. Conselho Monetário Nacional. Resolução 2.197/1995. Disponível em: < http://www.bcb.gov.br/pre/normativos/res/1995/pdf/res_2197_v1_O.pdf >. Acesso em 26/10/2011.

BANCO CENTRAL DO BRASIL. Conselho Monetário Nacional. Resolução 2.211/1995. Disponível em: < http://www.bcb.gov.br/pre/normativos/res/1995/pdf/res_2211_v1_O.pdf>. Acesso em 26/10/2011.

BANCO CENTRAL DO BRASIL. Conselho Monetário Nacional. Resolução 3.040/2002. Disponível em: < http://www.bcb.gov.br/pre/normativos/res/2002/pdf/res_3040_v1_O.pdf>. Acesso em 26/10/2011.

BANCO CENTRAL DO BRASIL. Conselho Monetário Nacional. Resolução 3.074/2003. Disponível em: < http://www.bcb.gov.br/pre/normativos/res/2003/pdf/res_3074_v1_O.pdf>. Acesso em 26/10/2011.

BANCO CENTRAL DO BRASIL. Conselho Monetário Nacional. Resolução 3.251/2004. Disponível em: < http://www.bcb.gov.br/pre/normativos/res/2004/pdf/res_3251_v1_O.pdf>. Acesso em 26/10/2011.

BANCO CENTRAL DO BRASIL. Conselho Monetário Nacional. Resolução 3.400/2006. Disponível em: < http://www.bcb.gov.br/pre/normativos/res/2006/pdf/res_3400_v1_O.pdf>. Acesso em 26/10/2011.

BANCO CENTRAL DO BRASIL. Conselho Monetário Nacional. Resolução 3.490/2007. Disponível em: < http://www.bcb.gov.br/pre/normativos/res/2007/pdf/res_3490_v1_O.pdf>. Acesso em 26/10/2011.

BANCO CENTRAL DO BRASIL. Conselho Monetário Nacional. Resolução 3.656/2008. Disponível em: < http://www.bcb.gov.br/pre/normativos/res/2008/pdf/res_3656_v1_O.pdf>. Acesso em 26/10/2011.

BANCO CENTRAL DO BRASIL. Conselho Monetário Nacional. Resolução 3.692/2009. Disponível em: < http://www.bcb.gov.br/pre/normativos/res/2009/pdf/res_3692_v1_O.pdf>. Acesso em 26/10/2011.

BANCO CENTRAL DO BRASIL. Conselho Monetário Nacional. Resolução 3.721/2009. Disponível em: < http://www.bcb.gov.br/pre/normativos/res/2009/pdf/res_3721_v1_O.pdf>. Acesso em 12/11/2012.

BANCO CENTRAL DO BRASIL. Conselho Monetário Nacional. Resolução 3.793/2009. Disponível em: < http://www.bcb.gov.br/pre/normativos/res/2009/pdf/res_3793_v1_O.pdf>. Acesso em 26/10/2011. 
BANCO CENTRAL DO BRASIL. Conselho Monetário Nacional. Resolução 3.931/2010. Disponível em: < http://www.bcb.gov.br/pre/normativos/res/2010/pdf/res_3931_v1_O.pdf>. Acesso em 26/10/2011.

BARBOSA, F. H. Política monetária: instrumentos, objetivos e a experiência brasileira. In: SAWAYA, R. R. (Org.). O Plano Real e a política econômica. São Paulo: Educ, 1996. p. 79-103.

BAUMOL, W. J. The transactions demand for cash: an inventory theoretic approach. Quarterly Journal of Economics. v. 66, p. 545-556, 1952.

BESSIS, J. Risk management in banking. Willey, Chichester: John Wiley e Sons, 1998.

BLANCHARD, O. J.; LOPEZ-DE-SILANES, F.; SHLEIFER, A. What do firms do with cash windfalls? Journal of Financial Economics. v. 36, n. 3, p. 337-360, 1994.

BOLETIM RISK BANK. Entendendo a Basiléia III. Lopes Filho e Associados, 2010. Disponível em: <http://www.riskbank.com.br/anexo/boletim0910.pdf>. Acesso em: 30/04/2011.

BOLETIM RISK BANK. O novo acordo de capital da Basiléia (Basiléia II). Lopes Filho e Associados, 2002. Disponível em: <http://www.riskbank.com.br/anexo/ basileia2.pdf>. Acesso em: 30/04/2011.

BORINELLI, M. Estrutura conceitual básica de controladoria: sistematização à luz da teoria e da praxis. São Paulo, 2006. Tese (Doutorado em Contabilidade) - Faculdade de Economia Administração e Contabilidade da Universidade de São Paulo.

BRITO, E. P. Z.; CAMPOS, L. A.; BRITO, L. A.; THOMAZ, J. C. Reputação corporativa e desempenho: Uma análise empírica no setor bancário. XXIX Encontro da Anpad EnANPAD, Brasília, 2005. Disponível em: < http://www.anpad.org.br/evento.php?acao $=$ trabalho\&cod_edicao_subsecao $=30 \&$ cod_evento_edicao $=9 \&$ cod_edicao_trabalho= 384>. Acesso em: 23/11/2011

BRITO, O. S. Contribuição ao estudo de modelo de controladoria risco-retorno em bancos de atacado. São Paulo, 2000. Tese (Doutorado em Contabilidade) - Faculdade de Economia Administração e Contabilidade da Universidade de São Paulo.

BRYMAN, A. Social research methods. 3rd ed. New York: Oxford, 2008.

CARVALHO, K. L.; SARAIVA JUNIOR, A. F.; FREZATTI, F.; COSTA, R. P. A contribuição das teorias do ciclo de vida organizacional para a pesquisa em contabilidade 
gerencial. RAM. Revista de Administração Mackenzie. São Paulo, v.11, n. 4, p. 98-130, 2010.

CARVALHO, S. A. Desenvolvimento de novas técnicas para a gestão bancária no Brasil. São Paulo, 1993. Tese (Doutorado em Contabilidade) - Faculdade de Economia Administração e Contabilidade da Universidade de São Paulo.

CATELLI, A. Controladoria: uma abordagem da Gestão Econômica - GECON. São Paulo: Atlas, 1999.

CATELLI, A.; PARISI, C.; SANTOS, E. S. Gestão econômica de investimentos em ativos fixos. Revista Contabilidade \& Finanças - USP. São Paulo, n. 31, p. 26-44, jan./abr. 2003.

CHAPMAN, C. S. Reflections on a contingent view of accounting. Accounting, Organizations and Society. v. 22, n. 2, p. 189-205, 1997.

CHENG, M.-Y.; TSAI, H.-C.; SUDJONO, E. Evolutionary fuzzy hybrid neural network for project cash flow control. Engineering Applications of Artificial Intelligence. v. 23, n. 4, p. 604-613, 2010.

CHENHALL, R. H. Management control systems design within its organizational context: findings from contingency-based research and directions for the future. Accounting Organizations and Society. v. 28, n.2-3, p. 127-168, 2003.

CHENHALL, R. H. Theorizing contingencies in management control systems research. Handbooks of Management Accounting Research. Elsevier, v. 1, p. 163-205, 2006.

CHRISTENSEN, C.; SCOTT, B. R. Review of course activities. Lausane : IMEDE, 1964.

CORAZZA, G. O Banco Central do Brasil: evolução histórica e institucional. Perspectiva Econômica. [S.1.], v. 2, n, 1, p. 1-23, jan./jun. 2006.

COSTA, A. C. A. O FGC ontem e hoje: 1995 a 2006. São Paulo, Tendências Consultoria Integrada, 2006. Disponível em: <http://www.fgc.org.br/?busca=n\%F9 mero>. Acesso em: $31 / 08 / 2011$.

COSTA. F. N. Bancos e crédito no Brasil: 1945 a 2007. História e Economia Revista Interdisciplinar. [S.1.], v. 4, n. 2, 2. sem. 2008.

COVALESKI, M.; EVANS III, J. H.; LUFT, J.; SHIELDS, M. D. Budgeting research: three theoretical perspectives and criteria for selective integration. Handbooks of Management Accounting Research. Elsevier, v. 2, p. 587-624, 2006. 
DAMODARAN, A. Corporate finance: theory and practice. New York, NY: John Wiley e Sons, 1997.

DAVILA, T. An exploratory study on the emergence of management control systems: formalizing human resources in small growing firms. Accounting, Organizations and Society. v. 30, n. 3, p. 223-248, 2005.

DENT, J. F. Global competition: challenges for management accounting and control. Management Accounting Research. v. 7, n. 2, p. 247-269, 1996.

DRAZIN, R.; VAN DE VEN, A. H. Alternative forms of fit in contingency theory. Administrative Science Quarterly. v. 30, n. 4, p. 514-539, 1985.

FÁVERO, L. P. L.; BELFIORE, P.; SILVA, F. L.; CHAN, B. L. Análise de dados: modelagem multivariada para tomada de decisões. Rio de Janeiro: Elsevier, 2009.

FEDERAL RESERVE. Risk management. Estados Unidos, 2010. Disponível em: <http://www.federalreserve.gov/monetarypolicy/bst_riskmanagement.htm>. Acesso em: 29/08/2011.

FIPECAFI. Estudo sobre a apuração do spread da indústria bancária. São Paulo: 2005.

FIPECAFI; FEBRABAN. Disponível em: <http://www.febraban.org.br/Arquivo/Destaques/ fipecafi_port_net.pdf $>$. Acesso em: 30/09/2011.

FISHER, J. Contingency-based research on management control systems: categorization by level of complexity. Journal of Accounting Literature. v. 14, p. 24-53, 1995.

FREZATTI, F. Gestão do fluxo de caixa diário: como dispor de um instrumento fundamental para o gerenciamento do negócio. São Paulo: Atlas, 1997.

FREZATTI, F. Orçamento empresarial: planejamento e controle gerencial. 5. ed. São Paulo: Atlas 2009.

FREZATTI, F.; JUNQUEIRA, E.; NASCIMENTO, A. R.; RELVAS, T. Análise do perfil de planejamento associado ao ciclo de vida organizacional nas empresas brasileiras. $11^{\circ}$ Congresso USP de Controladoria e Contabilidade, São Paulo, 2009. Disponível em: <http://www.congressousp.fipecafi.org/artigos92009/158.pdf/>. Acesso em: 12/08/2010

FUNDO GARANTIDOR DE CRÉDITOS. Disponível em: <http://www.fgc.org.br/ ?conteudo=1\&ci_menu=273>. Acesso em: 10/2011. 
GALLO, M. F. Uma Contribuição ao Estudo do Planejamento Tributário nos Processos de Fusão Incorporação e Cisão. São Paulo, 2002. Dissertação (Mestrado) - Centro Universitário Álvares Penteado da Fundação Escola de Comércio Álvares Penteado UNIFECAP

GARRISON, R.; NOREEN, E. W. Contabilidade gerencial. 9. ed. Rio de Janeiro: LTC, 2001.

GITMAN, L. J.; MOSES, E. A.; WHITE, I. T. An assessment of corporate cash management practices. Financial Management. v. 8, n. 1, 1979.

GONÇALVES, T.C. O sistema financeiro brasileiro: evolução do crédito no Brasil pósPlano Real. Trabalho de Conclusão de Curso de Graduação, Faculdade de Economia, Fundação Armando Alvares Penteado, [S.1.], 2007.

GRANLUND, M.; TAIPALEENMÄKI, J. Management control and controllership in new economy firms - a life cycle perspective. Management Accounting Research. v. 16, n.1, p. 21-57, 2005.

GREINER, L. E. Evolution and revolution as organizations grow. Harvard Business Review. v. 50, p. 37-46, 1972.

HEMPEL, G. H.; SIMONSON, D. G. Bank management: text and cases. 5th. ed. Wiley, New Jersey: John Wiley e Sons, 1998.

HOJI, M. Administração financeira: uma abordagem prática. 2. ed. São Paulo: Atlas 2000.

HORNGREN, C. T.; SUNDEM, G. L.; STRATTON, W. O. Contabilidade gerencial. São Paulo: Pearson Prentice Hall, 2004.

ITURRALDE, T.; MASEDA, A.; SAN-JOSE, L. Treasury management versus cash management. International Research Journal of Finance and Economics. n. 19, p. 192204, 2008.

ITURRALDE, T.; MASEDA, A.; SAN-JOSE, L. The cash management routines: evidence from Spanish case. Frontiers in Finance and Economics. v. 6, n. 1, p. 93-117, 2009.

IUDÍCIBUS, S.; MARTINS, E.; CARVALHO, L. N. Contabilidade: aspectos relevantes da epopéia de sua evolução. Revista de Contabilidade e Finanças. São Paulo, USP, v. 38, p. 7 19, 2005.

JÚNIOR, J.A.F.; DE PAULA, L. F. Fusões e aquisições bancárias e a evolução da eficiência técnica dos maiores bancos privados do Brasil. XXXVII Encontro Nacional de Economia, ANPEC, Foz do Iguaçu, PR, 2009. Disponível em: http://www.anpec.org.br/encontro2009/inscricao.on/arquivos/000-940cdeb9d0f2cdca003770 
c6f1bdd3ea.pdf/. Acesso em: 05/10/2011

KALLUNKI, J.-P.; SILVOLA, H. The effect of organizational life cycle stage on the use of activity-based costing. Management Accounting Research. v. 19, n. 1, p. 62-79, 2008.

KAMATH, R. R.; KHAKSARI, S.; HEIDI, H.I.; WINCKLEPLECK, J. Management of excess cash: practices and developments. Financial Management. v. 14, n. 3, p. 70-77, 1985.

KIM, C-.S.; MAUER, D. C.; SHERMAN, A. E. The determinants of corporate liquidity: theory and evidence. The Journal of Financial and Quantitative Analysis. v. 33, n. 3, p. 335-359, 1998.

KYTÖNEN, E. Cash management behavior of firms and its structural change in an emerging money market. Finlândia, 2004. (Dissertação Acadêmica) - Faculty of Economics and Business Administration, University of Oulu.

LEITE, M. R.; SILVA, H. F. N.; CHEROBIM, A. P. M. S.; BUFREM; L. S. Orçamento empresarial: levantamento da produção científica no período de 1995 a 2006. Revista de Contabilidade e Finanças. São Paulo, USP, v. 19, n. 47, p. 56-72, 2008.

LESTER, D. L.; PARNELL, J. A.; CARRAHER, S. Organizational life cycle: a five-stage empirical scale. International Journal of Organizational Analysis. v. 11, n. 7, p. 339-354, 1993.

LIMA, I. S.; LIMA. G. S.; PIMENTEL, R. C. Curso de mercado financeiro: tópicos especiais. São Paulo: Atlas, 2006.

LIPPITT, G. L.; SCHMIDT, W. H. Crises in a developing organization. Harvard Business Review. v. 45, n. 6, p. 102-112, 1967.

MAIA, G. V. S. Reestruturação Bancária no Brasil: O Caso PROER. Notas Técnicas do Banco Central do Brasil, $N^{\circ} 38$, junho, 2003

MARKOWITZ, H. M. Portfolio selection. Journal of Finance. v. 7, p.77-91, 1952.

MARTINS, G. A.; THEOPHILO, C. R. T. Metodologia da investigação científica para ciências sociais aplicadas. 2. ed. São Paulo: Atlas, 2009.

MEYER, A. D.; TSUI, A. S.; HININGS, C. R. Configurational approaches to organizational analysis. Academy of Management Journal. v. 36, n. 6, p.1175-1195, 1993.

MILLER, D. Configurations of strategy and structure: towards a synthesis. Strategic Management Journal. v. 7, n. 3, p. 233-249, 1986. 
MILLER, D. The genesis of configuration. The Academy of Management Review. v. 12, n. 4, p. 16, 1987.

MILLER, D.; FRIESEN, P. H. Archetypes of organizational transition. Administrative Science Quarterly. v. 25, n. 2, p. 268-299, 1980.

MILLER, D.; FRIESEN, P. H. Successful and unsuccessful phases of the corporate life cycle. Organization Studies. v. 4, n. 4, p. 339-356, 1983.

MILLER, D.; FRIESEN, P. H. A longitudinal study of the corporate life cycle. Management Science. v. 30, n. 10, p. 23, 1984.

MILLER, M.; ORR, D. A model of the demand for money by firms. Quarterly Journal of Economics. v. LXXIX, p. 413-435, 1966.

MOORES, K.; YUEN, S. Management accounting systems and organizational configuration: a life-cycle perspective. Accounting, Organizations and Society. v. 26, n. 4-5, p. 351-389, 2001.

OBRIEN, Y. Y. C. Reserve requirement systems in OECD countries. Finance and Economics Discussion Series Divisions of Research \& Statistics and Monetary Affairs, Federal Reserve Board, Washington, D.C., 2007. Disponível em: <http://www.federalreserve.gov/pubs/.../200754pap.pdf>. Acesso em: 25/09/2011.

ONO, F. H. O acordo de Basiléia, a adequação de capital e a implementação no sistema bancário brasileiro. Campinas, 2002. Trabalho de Conclusão de Curso de Graduação, Instituto de Economia, Universidade Estadual de Campinas.

OPLER, T.; PINKOWITZ, L.; STULZ, R.; WILLIAMSON, R. The determinants and implications of corporate cash holdings. Journal of Finance and Economics. n. 52, p. 3-46, 1999.

OTLEY, D. T. The contingency theory of management accounting: achievement and prognosis. Accounting, Organizations and Society. v. 5, n. 4, p. 413-428, 1980.

OZKAN, A.; OZKAN, N. Corporate cash holdings: an empirical investigation of UK companies. Journal of Banking e Finance. v. 28, n. 9, p. 2103-2134, 2004.

PEROBELLI, F. F. C.; JANUZZI, F. V.; BELBERT, L. S.; MEDEIROS, D. S. Testando diferentes métodos de estimação do cash flow at risk. Faculdade de Economia e Administração da Universidade Federal de Juiz de Fora. Juiz de Fora, Texto para Discussão, 2007. Disponível em: <http://www.ufjf.br/poseconomia/publicações-e-seminarios/textos- 
para-discussao/ano2007/td-0052007-testando-diferentes-metodos-de-estimacao-do-cash-flowat-risk/>. Acesso em: 02/12/2010.

PHILLIPS, A. Treasury management: job responsibilities, curricular development, and research opportunities. Financial Management. v. 26, n. 3, p. 59-81, 1997.

PRADO, J. M.; MARTINS, H. C. Gestão de riscos operacionais: adequações decorrentes de sua implementação em uma instituição bancária. XII Simpósio de Administração da Produção, Logística, e Operações Internacionais, São Paulo, 2009. Disponível em: <http://www.simpoi.fgvsp.br/arquivo/2009/artigos/E2009_T00155_PCN79216.pdf>. Acesso em: 29/03/2011

QUINN, R. E.; CAMERON, K. Organizational life cycles and shifting criteria of effectiveness: some preliminary evidence. Management Science. v. 29, n. 1, p. 33-51, 1983.

RHENMAN, E.; ADLER, N. Organization theory for long-range planning. London: Wiley Chichester, 1973.

ROGERS, P.; ROGERS, D.; RIBEIRO, K. C. S. Risco, retorno e liquidez na administração de caixa: integração do Modelo de Miller-Orr com a probabilidade de exaustão dos recursos líquidos. Xl Asamblea Consejo Latinoamericano De Escuelas De Administracion, Santiago do Chile, 2005.

SANTOS, A. C. S. Controladoria no Banco do Brasil S. A. Uma contribuição ao estudo da controladoria em instituições financeiras. Porto Alegre, 2005. Dissertação (Mestrado) Universidade Federal do Rio Grande do Sul.

SELTO, F. H.; RENNER, C. J.; YOUNG, S. M. Assessing the organizational fit of a just-intime manufacturing system: Testing selection, interaction and systems models of contingency theory. Accounting, Organizations and Society. v. 20, n. 7-8, p. 665-684, 1995.

SILVA, D. Z. G.; NEIVA, R. M. O fluxo de caixa como ferramenta de gestão financeira e estratégia nas empresas. ReFAE - Revista da Faculdade de Administração e Economia. São Paulo, Universidade Metodista, v. 2, n. 2, p. 23-35, 2010.

SILVOLA, H. S. Do organizational life-cycle and venture capital investors affect the management control systems used by the firm? Advances in Accounting, Incorporating Advances in International Accounting. v. 24, p. 128-138, 2008a.

SILVOLA, H. S. Design of MACS in growth and revival stages of the organizational lifecycle. Qualitative Research in Accounting e Management. v. 5, n. 1, p. 27-47, 2008b.

SOENEN, L.A. International cash management: a study of the practices of U.K.-based companies. Journal of Business Research. v.14, n. 4, p.345-354, 1986. 
SOENEN, L. A.; AGGARWAL, R. Cash and foreign exchange management: theory and corporate practice in three countries. Journal of Business Finance and Accounting. v. 16, n. 5, p. 599-619, 1989.

SOUZA, B. C.; NECYK, G. A.; FREZATTI, F. Ciclo de vida das organizações e a contabilidade gerencial. I Congresso ANPCONT, Gramado, 2007. Disponível em: <http://www.anpcont.com.br/site/docs/congressoI/01/CCG089.pdf>. Acesso em: 12/08/2010

VAN DER STEDE, W. A. Measuring 'tight budgetary control. Management Accounting Research. v. 12, n. 1, p. 119-137, 2001.

VERBETEEN, F. H. M. Do organizations adopt sophisticated capital budgeting practices to deal with uncertainty in the investment decision?: a research note. Management Accounting Research. v. 17, n. 1, p. 106-120, 2006.

VIEIRA, S. A. O Processo de Privatização dos Bancos Estaduais e o PROES. Revista Pensar Contábil, Rio de Janeiro, v. 9, n. 37, p. 36 - 42, jul./set. 2007.

WELSCH, G. A. Orçamento empresarial. 4. ed. São Paulo: Atlas, 1983.

YIN, R. K. Estudo de caso: planejamentos e métodos. 4. ed. Porto Alegre: Bookman, 2010.

ZDANOWICZ, J. E. Fluxo de caixa: uma decisão de planejamento e controle financeiros. 5. ed. Porto Alegre: Sagra - DC Luzzatto, 1995. 


\section{APÊNDICES}

APÊNDICE 1 - QUESTIONÁRIO

APÊNDICE 2 - ROTEIRO PARA ENTREVISTAS

APÊNDICE 3 - QUADROS AUXILIARES 


\section{APÊNDICE 1 - QUESTIONÁRIO}

\section{Cláusula de Confidencialidade}

Este instrumento de coleta de dados é parte integrante da pesquisa denominada O Processo de Gestão e Controle dos Fluxos de Caixa em um Banco Brasileiro: Uma Abordagem à Luz do Ciclo de Vida Organizacional, realizada pelo mestrando do Programa de Pós-Graduação em Controladoria e Contabilidade, da Faculdade de Economia, Administração e Contabilidade da Universidade de São Paulo, Cristiano Prudencio, conjuntamente com o Professor Doutor Carlos Alberto Pereira, seu orientador.

Toda informação presente nas respostas das questões será tratada como confidencial e restrita, não sendo alvo de qualquer divulgação. Apenas as conclusões da pesquisa serão divulgadas, sendo estas em caráter agregado e trabalhado, sem qualquer dado bruto. Não haverá necessidade de identificação do respondente, sendo esta realizada de forma espontânea.

\section{Seção A - Caracterização do Respondente}
1. Sexo
- Masculino
○ Feminino

\section{Tempo na Instituição (Questão Aberta)}

\section{3. Área a qual pertence}

○ Finanças

○ Riscos

○ Tesouraria 
4. As decisões tomadas nos eventos de acompanhamento formal de gestão e controle de fluxos de caixa em sua organização impactam as ações de gestão de caixa no longo prazo, possuindo influência sistêmica e abrangente inclusive no direcionamento geral do banco.

○ Discordo totalmente

○ Discordo parcialmente

○ Não concordo nem discordo

○ Concordo parcialmente

- Concordo totalmente

5. Em relação ao processo de gestão e controle dos fluxos de caixa desenvolvido em sua organização, os gestores das áreas de negócios são responsáveis pelas projeções, pela análise dos desvios destas em relação ao efetivamente ocorrido, além de participarem da definição de modelos e de políticas relacionadas ao caixa.

○ Discordo totalmente

- Discordo parcialmente

○ Não concordo nem discordo

- Concordo parcialmente

○ Concordo totalmente

6. Sua organização possui política de liquidez, acompanhamento do risco de liquidez, bem como definição e controle de limites relacionados à liquidez.

○ Discordo totalmente

○ Discordo parcialmente

○ Não concordo nem discordo

- Concordo parcialmente

- Concordo totalmente

7. Sua organização se utiliza unicamente de equipes internas especializadas na definição e identificação de políticas, limites, riscos e controles de liquidez.

○ Discordo totalmente 
○ Discordo parcialmente

○ Não concordo nem discordo

○ Concordo parcialmente

○ Concordo totalmente

8. De forma geral, em relação aos gestores das áreas de negócio em sua organização é possível afirmar que estes são ativamente participantes da gestão do caixa, e constantemente tomam iniciativas que colaboram beneficamente para as áreas sob sua gestão, bem como para o banco como um todo.

- Discordo totalmente

○ Discordo parcialmente

○ Não concordo nem discordo

○ Concordo parcialmente

- Concordo totalmente

9. Tratando-se da gestão e do controle do caixa propriamente constituídos é correto afirmar que em sua organização este processo é descentralizado, contando com a participação de diversas áreas e de diversos profissionais de hierarquias distintas.

○ Discordo totalmente

○ Discordo parcialmente

○ Não concordo nem discordo

○ Concordo parcialmente

- Concordo totalmente

Seção C-Características informacionais e tecnológicas do processo

10. Em sua organização os fluxos de caixa são projetados e analisados de forma bem analítica, sendo observadas subdivisões de fluxos de caixa por segmento de negócios, por região geográfica, por produto, por Cosif e até mesmo por cliente.

○ Discordo totalmente

○ Discordo parcialmente

○ Não concordo nem discordo

- Concordo parcialmente 
○ Concordo totalmente

11. Em sua organização, os relatórios de fluxos de caixa apresentados às áreas de negócio são todos customizados, ou seja, cada relatório de cada área de negócio é formatado de acordo com a sua necessidade informacional e gerencial, não existindo relatórios gerais padronizados.

○ Discordo totalmente

○ Discordo parcialmente

○ Não concordo nem discordo

○ Concordo parcialmente

○ Concordo totalmente

12. É possível afirmar que em sua organização existem pouquíssimas ou uma única fonte que fornece todos os dados necessários para gerar a informação integral de fluxos de caixa do banco, sem necessidade de grandes processos de consolidação nem de conciliação, em razão dessa ser íntegra e fidedigna.

○ Discordo totalmente

○ Discordo parcialmente

○ Não concordo nem discordo

- Concordo parcialmente

- Concordo totalmente

13. O processamento, elaboração e controle dos fluxos de caixa são realizados totalmente ou predominantemente num sistema integrado, como um ERP (Enterprise Resource Planning).

○ Discordo totalmente

- Discordo parcialmente

○ Não concordo nem discordo

- Concordo parcialmente

○ Concordo totalmente

14. O fluxo de informações que transita por meio dos sistemas e ferramentas utilizados no processo de gestão e controle dos fluxos de caixa é conhecido por todos os envolvidos, 
desde a gestão das áreas de negócios até a gestão corporativa, partindo da entrada e processamento de informações até a saída dos relatórios e análises.

○ Discordo totalmente

○ Discordo parcialmente

○ Não concordo nem discordo

○ Concordo parcialmente

○ Concordo totalmente

Seção D - Características técnicas e utilização

15. Nas projeções de fluxos de caixa realizadas na sua organização são utilizadas técnicas de estatística avançadas como regressões, dados em painel, e outras técnicas multivariadas de estatística, bem como indicadores macroeconômicos como taxas de juros, inflação, PIB, câmbio, e microeconômicos como inadimplência e demandas por serviços.

○ Discordo totalmente

- Discordo parcialmente

○ Não concordo nem discordo

- Concordo parcialmente

- Concordo totalmente

16. As projeções de fluxos de caixa são geradas por informações obtidas a partir do processo orçamentário anual do banco, atualizado mensalmente (rolling forecast), utilizando para essa tarefa o método de fluxo de caixa indireto gerado por cálculos baseados nos saldos, receitas e despesas orçados.

○ Discordo totalmente

- Discordo parcialmente

○ Não concordo nem discordo

- Concordo parcialmente

- Concordo totalmente

17. Existem projeções de fluxos de caixa para os seguintes horizontes futuros: 
- No máximo até os próximos 12 meses

- No máximo até os próximos 24 meses

- No máximo até os próximos 36 meses

- No máximo até os próximos 48 meses

- No máximo até os próximos 60 meses

○ Além dos próximos 60 meses

18. As projeções de fluxos de caixa são atualizadas de acordo com a seguinte periodicidade:

○ Diariamente

- Semanalmente

○ Quinzenalmente

○ Mensalmente

○ Trimestralmente

○ Semestralmente

○ Anualmente

- Superior às descritas acima

19. Existe na sua organização uma estrutura formal de reunião, conselho ou comitê de acompanhamento da gestão e controle dos fluxos de caixa, sendo este realizado com a seguinte periodicidade:

○ Diariamente

- Semanalmente

○ Quinzenalmente

○ Mensalmente

○ Trimestralmente

○ Semestralmente

- Anualmente

○ Não existe esse tipo de evento

20. Com relação às discussões e definições geradas a partir da apresentação das informações referentes ao processo de gestão e controle dos fluxos de caixa se pode afirmar que todos os envolvidos nas apresentações das informações, desde a gestão das 
áreas de negócios até a gestão corporativa, participam também das discussões dos pontos levantados e colaboram com o processo decisório gerando definições conjuntas.

- Discordo totalmente

- Discordo parcialmente

○ Não concordo nem discordo

- Concordo parcialmente

○ Concordo totalmente

21. A análise real $x$ previsto dos fluxos de caixa gera ações de gestão efetivas, quer sejam essas corretivas ou preventivas.

○ Discordo totalmente

- Discordo parcialmente

○ Não concordo nem discordo

○ Concordo parcialmente

- Concordo totalmente

22. Em sua organização existem indicadores de desempenho relacionados à gestão e controle dos fluxos de caixa, sendo estes presentes tanto na alta administração como em níveis inferiores.

○ Discordo totalmente

○ Discordo parcialmente

○ Não concordo nem discordo

- Concordo parcialmente

○ Concordo totalmente

Seção E-Ciclo de Vida Organizacional

23. Quanto ao tamanho, sua organização é:

- Pequena, tanto em tamanho quanto em relação aos seus concorrentes

○ Maior que a maioria de nossos competidores, porém não tão grandes como poderíamos ser

- Uma das maiores organizações presente no nosso mercado

○ Nem tão grande nem tão pequena 


\section{Quanto ao controle acionário, em sua organização ele se encontra:}

○ Amplamente disperso, com quadro de diretores e acionistas

○ Primeiramente nas mãos do fundador

○ Pulverizado num grupo de diversos sócios/investidores.

○ Concentrado num vasto grupo de acionistas.

\section{Quanto à estrutura e modelo de gestão geral, sua organização:}

○ Pode ser adequadamente descrita como simples

○ É funcional e baseada em departamentos, tornando-se muito mais formal

○ É de natureza divisional ou matricial, com sistemas de controle altamente sofisticados.

○ É formal e bem hierarquizada, porém não é muito complexa

26. Quanto ao processamento de informações na sua organização, pode-se afirmar que:

○ Esse pode ser descrito como simples, e predominantemente como boca a boca.

○ Esse pode ser caracterizado pelo monitoramento de desempenho e pela facilitação da comunicação entre os departamentos.

- Esse é sofisticado e necessário para a eficiência produtiva e para gerar lucros adequados.

- Esse é bastante complexo, utilizado para a coordenação de diversas atividades para melhor servir os mercados.

○ Esse não é muito sofisticado, porém um mal necessário

\section{Quanto ao direcionamento estratégico, a sua organização:}

○ Possui foco no pioneirismo, destacando-se pela liderança tecnológica

○ Possui foco em diferenciar-se, sendo mais eficiente e eficaz que seus concorrentes, apesar de não se destacar como pioneira no mercado.

○ Possui foco na manutenção e defesa de sua posição no mercado

○ Possui foco na busca pelo menor custo em relação à sua concorrência

○ Possui foco na diversificação dos seus produtos

28. Quanto ao processo decisório, em sua organização pode-se afirmar que:

○ É centralizado no topo da organização e não é considerado complexo 
- A maioria das decisões é tomada por grupo de gestores que fazem uso de análises sistemáticas, porém são bastante ousados

- A maioria das decisões é tomada por grupo de gestores, forças tarefas, e equipes de projetos, que estão buscando facilitar o crescimento pela participação.

- A maioria das decisões é tomada por poucos gestores que são conservadores e possuem abordagem internamente política.

29. O ambiente comercial em que sua organização está inserida pode ser descrito como:

- Simples e com pouca segmentação de mercado

- Competitivo

○ Um tanto quanto complexo e com muita segmentação de mercado

- Muito complexo e muito segmentado

○ Simples, porém competitivo

30. Sua organização está satisfeita com seu desempenho

- Discordo totalmente

- Discordo parcialmente

○ Não concordo nem discordo

- Concordo parcialmente

○ Concordo totalmente

31. Sua organização é eficiente.

- Discordo totalmente

○ Discordo parcialmente

○ Não concordo nem discordo

- Concordo parcialmente

- Concordo totalmente 


\section{APÊNDICE 2 - ROTEIRO PARA ENTREVISTAS}

1 - Em sua opinião o processo de gestão e controle dos fluxos de caixa é adequadamente acompanhado, conta com a participação de todos os envolvidos e está adequadamente formatado em termos de controle e riscos?

2 - Segundo seu conhecimento, as decisões advindas do processo de gestão e controle do caixa sensibilizam todos os colaboradores necessários, de modo que há congruência de objetivos entre as áreas, fluidez na comunicação e execução das decisões tomadas?

3 - De acordo com seu conhecimento, você pode afirmar que as estruturas técnica e tecnologia são as mais adequadas para atender as necessidades dos envolvidos no processo de gestão e controle dos fluxos de caixa, sendo considerada "high-tech" em termos tecnológicos e bastante sofisticada em termos técnicos?

4 - Em sua opinião, o timing, a customização e a granularidade da informação de fluxos de caixa é a ideal para a condução do processo de gestão e controle dos fluxos de caixa?

5 - É de seu conhecimento que indicadores advindos do processo de gestão e controle dos fluxos de caixa sejam parte integrante da avaliação de desempenho das áreas captadoras e aplicadoras de recursos? Caso não, isso deveria ocorrer?

6 - O orçamento é parte integrante do processo de gestão e controle dos fluxos de caixa? Caso sim, as chamadas reservas orçamentárias não viriam a interferir na qualidade e dinamismo do processo de gestão? Caso não, como conviver com instrumentos distintos e dissonantes?

7 - Em sua opinião sua instituição é maior que seus concorrentes, se destaca unicamente pelo seu pioneirismo e liderança tecnológica, possuindo controle acionário amplamente disperso e um processo decisório altamente descentralizado? Caso contrário, qual ponto é divergente em sua opinião? 
8 - Os processos de comunicação e processamento de informações são simples e adequados ao ambiente homogêneo em que sua organização opera. Você concorda na íntegra com essa informação?

9 - Em sua opinião, sua organização pode ser considerada eficiente e plenamente satisfeita em relação ao seu desempenho? 


\section{APÊNDICE 3 - QUADROS AUXILIARES}

\section{A.3.1 - Pré-teste - Alfa de Cronbach do questionário}

Quadro A.3.1 - Resultado do teste Alfa de Cronbach

\begin{tabular}{|c|c|c|c|c|c|c|}
\hline Item & Obs & Sig & $\begin{array}{l}\text { item-test } \\
\text { correlation }\end{array}$ & $\begin{array}{l}\text { item-rest } \\
\text { correlation }\end{array}$ & $\begin{array}{c}\text { average } \\
\text { inter-item } \\
\text { covariance }\end{array}$ & alpha \\
\hline Q4 & 7 & - & 0,6216 & 0,5724 & 0,4111 & 0,8692 \\
\hline Q5 & 7 & + & 0,5000 & 0,4286 & 0,4157 & 0,8730 \\
\hline Q6 & 7 & + & 0,9626 & 0,9593 & 0,4135 & 0,8664 \\
\hline Q7 & 7 & + & 0,6273 & 0,5936 & 0,4225 & 0,8705 \\
\hline Q8 & 7 & + & 0,1367 & 0,0754 & 0,4502 & 0,8803 \\
\hline Q9 & 7 & + & 0,8281 & 0,7974 & 0,3853 & 0,8617 \\
\hline Q10 & 7 & - & 0,6709 & 0,5921 & 0,3811 & 0,8684 \\
\hline Q11 & 7 & + & 0,1516 & 0,0673 & 0,4491 & 0,8830 \\
\hline Q12 & 7 & + & 0,2824 & 0,2244 & 0,4272 & 0,8645 \\
\hline Q13 & 7 & + & 0,5075 & 0,4585 & 0,4250 & 0,8724 \\
\hline Q14 & 7 & - & 0,4787 & 0,4100 & 0,4194 & 0,8734 \\
\hline Q15 & 7 & - & 0,4725 & 0,4034 & 0,4200 & 0,8736 \\
\hline Q16 & 7 & + & 0,3074 & 0,2494 & 0,4522 & 0,8895 \\
\hline Q17 & 7 & - & $-0,0070$ & $-0,0280$ & 0,4559 & 0,8790 \\
\hline Q18 & 7 & + & 0,7082 & 0,6373 & 0,3769 & 0,8664 \\
\hline Q19 & 7 & + & 0,7082 & 0,6373 & 0,3769 & 0,8664 \\
\hline Q20 & 7 & + & 0,4072 & 0,3526 & 0,4318 & 0,8746 \\
\hline Q21 & 7 & - & 0,0859 & $-0,0178$ & 0,4572 & 0,8885 \\
\hline Q22 & 7 & + & 0,3743 & 0,2872 & 0,4263 & 0,8778 \\
\hline Q23 & 7 & - & 0,9626 & 0,9593 & 0,4135 & 0,8664 \\
\hline Q24 & 7 & + & 0,2949 & 0,2369 & 0,4397 & 0,8770 \\
\hline Q25 & 7 & - & 0,6843 & 0,6600 & 0,4250 & 0,8705 \\
\hline Q26 & 7 & + & 0,3125 & 0,2773 & 0,4439 & 0,8762 \\
\hline Q27 & 7 & - & 0,6371 & 0,6206 & 0,4374 & 0,8735 \\
\hline Q28 & 7 & - & 0,1451 & 0,0838 & 0,4497 & 0,8801 \\
\hline Q29 & 7 & + & 0,7342 & 0,6916 & 0,3963 & 0,8653 \\
\hline Q30 & 7 & + & 0,9704 & 0,9673 & 0,4056 & 0,8643 \\
\hline Q31 & 7 & + & 0,7079 & 0,6600 & 0,3967 & 0,8660 \\
\hline Teste & & & & & 0,4202 & 0,8770 \\
\hline
\end{tabular}




\section{A.3.2. - Quadro relacional entre estágios do ciclo de vida e questões propostas}

\section{Quadro A.3.2 - Questões x Ciclos de Vida Organizacional}

\begin{tabular}{|c|c|c|c|c|c|}
\hline & & & Estágios & & \\
\hline Questão & Existencia & Sobrevivência & Sucesso & Renovação & Declínio \\
\hline $\begin{array}{l}\text { 4. As decisões } \\
\text { tomadas nos eventos } \\
\text { de acompanhamento } \\
\text { formal de gestão.. }\end{array}$ & 2 & 3 & 4 & 5 & 1 \\
\hline $\begin{array}{l}\text { 5. Em relação ao } \\
\text { processo de gestão } \\
\text { e controle dos fluxos } \\
\text { de caixa }\end{array}$ & 2 & 3 & 4 & 5 & 1 \\
\hline $\begin{array}{l}\text { 6. Sua organização } \\
\text { possui política de } \\
\text { liquidez, } \\
\text { acompanhamento... }\end{array}$ & 2 & 3 & 4 & 5 & 1 \\
\hline $\begin{array}{l}\text { 7. Sua organização } \\
\text { se utiliza unicamente } \\
\text { de equipes internas } \\
\text { especializadas na... }\end{array}$ & 2 & 3 & 4 & 5 & 1 \\
\hline $\begin{array}{l}\text { 8. De forma geral, em } \\
\text { relação aos gestores } \\
\text { das áreas de negócio } \\
\text { em sua }\end{array}$ & 2 & 3 & 4 & 5 & 1 \\
\hline $\begin{array}{l}\text { 9. Tratando-se da } \\
\text { gestão e do controle } \\
\text { do caixa } \\
\text { propriamente... }\end{array}$ & 2 & 3 & 4 & 5 & 1 \\
\hline $\begin{array}{l}\text { 10. Em sua } \\
\text { organização os } \\
\text { fluxos de caixa são } \\
\text { projetados... }\end{array}$ & 2 & 3 & 4 & 5 & 1 \\
\hline $\begin{array}{l}\text { 11. Em sua } \\
\text { organização, os } \\
\text { relatórios de fluxos } \\
\text { de caixa }\end{array}$ & 2 & 3 & 4 & 5 & 1 \\
\hline $\begin{array}{l}\text { 12. É possível afirmar } \\
\text { que em sua } \\
\text { organização existem } \\
\text { pouquíssimas... }\end{array}$ & 2 & 3 & 4 & 5 & 1 \\
\hline $\begin{array}{l}\text { 13. O } \\
\text { processamento, } \\
\text { elaboração e controle } \\
\text { dos fluxos de caixa }\end{array}$ & 2 & 3 & 4 & 5 & 1 \\
\hline $\begin{array}{l}\text { 14. O fluxo de } \\
\text { informações que } \\
\text { transita por meio dos } \\
\text { sistemas... }\end{array}$ & 2 & 3 & 4 & 5 & 1 \\
\hline $\begin{array}{l}\text { 15. Nas projeções de } \\
\text { fluxos de caixa } \\
\text { realizadas na sua } \\
\text { organização... }\end{array}$ & 2 & 3 & 4 & 5 & 1 \\
\hline $\begin{array}{l}\text { 16. As projeções de } \\
\text { fluxos de caixa são } \\
\text { geradas por } \\
\text { informações... }\end{array}$ & 2 & 3 & 4 & 5 & 1 \\
\hline $\begin{array}{l}\text { 17. Existem } \\
\text { projeções de fluxos } \\
\text { de caixa para os } \\
\text { seguintes }\end{array}$ & 1 & $\begin{array}{c}1 \text { ou } 2 \text { (com } \\
\text { predominancia de } \\
1)\end{array}$ & 2,3 ou 4 & 5 ou 6 & 1 ou 2 \\
\hline
\end{tabular}




\begin{tabular}{|c|c|c|c|c|c|}
\hline & & & Estágios & & \\
\hline Questão & Existencia & Sobrevivência & Sucesso & Renovação & Declínio \\
\hline $\begin{array}{l}\text { 18. As projeções de } \\
\text { fluxos de caixa são } \\
\text { atualizadas de } \\
\text { acordo com as }\end{array}$ & 7 & 4,5 ou 6 & 4 & 1,2 ou 3 & $5,6,7$ ou 8 \\
\hline $\begin{array}{l}\text { 19. Existe na sua } \\
\text { organização uma } \\
\text { estrutura formal de } \\
\text { reunião, conselho... }\end{array}$ & 7 & 4,5 ou 6 & 4 & 1,2 ou 3 & $5,6,7$ ou 8 \\
\hline $\begin{array}{l}\text { 20. Com relação às } \\
\text { discussões e } \\
\text { definições geradas a } \\
\text { partir da... }\end{array}$ & 2 & 3 & 4 & 5 & 1 \\
\hline $\begin{array}{l}\text { 21. A análise real } x \\
\text { previsto dos fluxos } \\
\text { de caixa gera ações } \\
\text { de gestão efetivas... }\end{array}$ & 2 & 3 & 4 & 5 & 1 \\
\hline $\begin{array}{l}\text { 22. Em sua } \\
\text { organização existem } \\
\text { indicadores de } \\
\text { desempenho... }\end{array}$ & 2 & 3 & 4 & 5 & 1 \\
\hline $\begin{array}{l}\text { 23. Quanto ao } \\
\text { tamanho sua } \\
\text { organização... }\end{array}$ & 1 & 4 & 2 & 3 & 1,2 ou 4 \\
\hline $\begin{array}{l}\text { 24. Quanto ao } \\
\text { controle em sua } \\
\text { organização ele se } \\
\text { encontra... } \\
\end{array}$ & 2 & 4 & 1 & 3 & 1,2 ou 4 \\
\hline $\begin{array}{l}\text { 25. Quanto à } \\
\text { estrutura e modelo de } \\
\text { gestão geral sua } \\
\text { organização... } \\
\end{array}$ & 11 & 4 & 2 & 3 & 1 ou 4 \\
\hline $\begin{array}{l}\text { 26. Quanto ao } \\
\text { processamento de } \\
\text { informações na sua } \\
\text { organização, pode- }\end{array}$ & 1 & 2 & 3 & 4 & 5 \\
\hline $\begin{array}{l}\text { 27. Quanto ao } \\
\text { direcionamento } \\
\text { estratégico a sua } \\
\text { organização... } \\
\end{array}$ & 4 & 2 & 3 & 1 ou 5 & 3 \\
\hline $\begin{array}{l}\text { 28. Quanto ao } \\
\text { processo decisório } \\
\text { em sua organização } \\
\text { pode-se afirmar... }\end{array}$ & 1 & 1 & 2 & 3 & 4 \\
\hline $\begin{array}{l}\text { 29. O ambiente } \\
\text { comercial em que sua } \\
\text { organização está } \\
\text { inserida pode... }\end{array}$ & 1 & 5 & 2 ou 3 & 4 & 2,3 ou 4 \\
\hline $\begin{array}{l}\text { 30. Sua organização } \\
\text { está satisf eita com } \\
\text { seu desempenho... }\end{array}$ & 2 & 3 & 4 & 5 & 1 \\
\hline $\begin{array}{l}\text { 31. Sua organização } \\
\text { é eficiente... }\end{array}$ & 2 & 3 & 4 & 5 & 1 \\
\hline
\end{tabular}

